Louisiana State University

LSU Digital Commons

1943

\title{
The Role of the Land Grant in the Social Organization and Social Processes of a Spanish-American Village in New Mexico.
}

Olen E. Leonard

Louisiana State University and Agricultural \& Mechanical College

Follow this and additional works at: https://digitalcommons.Isu.edu/gradschool_disstheses

Part of the Sociology Commons

\section{Recommended Citation}

Leonard, Olen E., "The Role of the Land Grant in the Social Organization and Social Processes of a Spanish-American Village in New Mexico." (1943). LSU Historical Dissertations and Theses. 7875. https://digitalcommons.Isu.edu/gradschool_disstheses/7875

This Dissertation is brought to you for free and open access by the Graduate School at LSU Digital Commons. It has been accepted for inclusion in LSU Historical Dissertations and Theses by an authorized administrator of LSU Digital Commons. For more information, please contact gradetd@lsu.edu. 
THE ROLE OF THE LAND GRANT IN THE SOCIAL ORGANI ZATION AND SOCIAL PROCESSFS OP A

SPANISH-AMERICAN VILIAGE IN NEW MEXICO

A Thesis
Subnet ted to the Graduate Facul ty of the Loulsiana State Un1versity and Agrioul tural and heohanical Coll ege in partial fulfiliment of the requirements for the degree of Doctor of Philosophy

in

The Department of Soclology

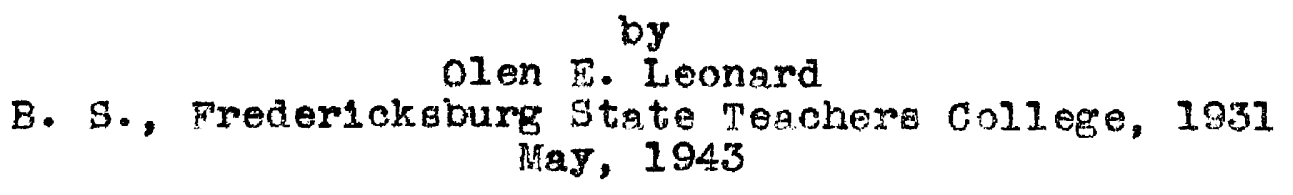


UMI Number: DP69253

All rights reserved

INFORMATION TO ALL USERS

The quality of this reproduction is dependent upon the quality of the copy submitted.

In the unlikely event that the author did not send a complete manuscript and there are missing pages, these will be noted. Also, if material had to be removed, a note will indicate the deletion.

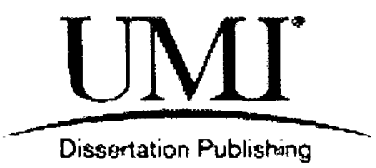

UMI DP69253

Published by ProQuest LLC (2015). Copyright in the Dissertation held by the Author. Microform Edition (c) ProQuest LLC.

All rights reserved. This work is protected against unauthorized copying under Title 17, United States Code

\section{ProQuest}

ProQuest LLC.

789 East Eisenhower Parkway

P.O. Box 1346

Ann Arbor, MI $48106-1346$ 


\section{ACXNOWLRDGYIENT}

I whe to alknowledge wy appreatation to Dr. Gaxl C. Taylor and Dr. Chac. P. Loomis who rirat interested we in raral soclology and wo ande the fleld work for the stady pesatble.

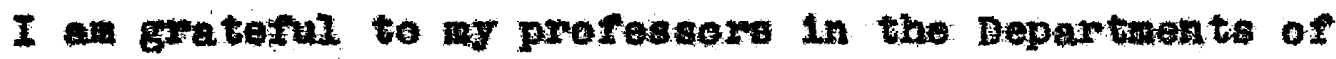
Soclology and Anthropology for ftimulating guldance in clase wexk and a conotant wlilingnese and desire to ald their etudents by every means posalble.

To profesen T. Lym smith, Fend of the Departments of Boelology and Pural Sootology of the Loul Lana State Eniversity, and my jor profesaor, I an particularly grateful. His orer patient encouragenent and oonstructive critlelema are langely reaponsible for any arits this Btudy may have.

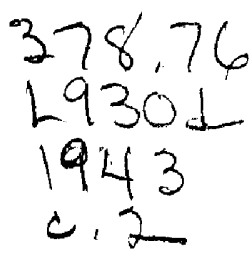


TABLE OF CONTENTE

CHAPTER

PAGE

I. INTRODUCTION . . . . . . . . . . . . I I

Hature and purpose of study . . . . . . .

Scope of the study .............. 2

Methodology . . . . . . . . . . . . . 4

Rev1ew of sel eoted 11 terature . . . . . . 6

order of procedure............. 11

II. GENIGRAL CHARACTERTSTICS OF THE AREA . . . . 13

The land.... . . . . . . . . . . . 13

The elluate . . . . . . . . . . . ... 16

Economle bases of gubsistence . . . . . . 18

The people ................... 20

III. EL CERRTTO AS A TMPE SITUATION . . . . . . 26

The nature of Spaniah-American cul ture in

New Hexico . . . . . . . . . . . . . 26

The alatribution of Spaniah-American oul ture

in New Hexico . . . . . . . . . . . 37

The development of Spanish-American culture

In New Hexico . . . . . . . . . . . . . 39

The upper pecos taterahed as a special ares 43

El Cerrito a type situation... . . . 46

IV. CHARACTERISTTCS AND DESCRIPTION OF EL CERPITO 48

Description ................ . . 48

H18 tory and Background.......... 50

The land; ownership and use . . . . . . 62

Tochniques of agriculture . . . . . . . 66

Heal th and medical facilities . . . . . . 73

Reoreation and amusent .......... 76

Religion and the church ......... 79

Soolal Participation........... 83

Marriage and the family . . . . . . . . 86

Education . . . ............. 9 ...

Polttlcs ................... 95

Level of living . . . . . . . . . . . 98 
V. THE ROLE OF THE LAND GRANT IN THE SOCIAL OROANIZATION AND SOCIAL PROCESSES OF A SPANISH-AMTRRTCAN VILIAGE IN NRV MLXICO . . . . . 101

Brief history of the land grant in New mex100. 103 The land grant in 1 ts relations to settlement patterng in El cerrito . . . . . . . . . . . 128 Thi land grant, survers and titles, and 1 and division in El Cerrito.............. 133 The land grant and land tenure in gl cerrito. . 141 The land Brant and ize of holdings in El Cerrito..................... 144

Land grants as a conditioning factor in the
rural soolal prooesses of til cerrito .... 149

1. Competition, conflict and cooperation . . 149

2. Aeemmodation, aseimilation, and acoulturatión............. 154

3. Social atratifleation........... . 159

4. Soclal institutions. . . . . . . . . . 163

5. Migration.................. 170

6. Soo1al nob111ty ............... 172

VI. SUMART AND CONCLESTONS . . . . . . . . . . 176

APPEADIX A . . . . . . . . .......... 187

APPINDIX B . . . . . . . . . . . . . . 197

BIBLIOGRAPHY . . . . . . . . . . . . . . 208

BIOARAPHY . . . . . . . . . . . . . . . 213 


\section{LIST OF TABLES}

TABLE

PACE

I. SPANTSH-SPLAKING POPULATTON OF CERTATN SELECTED COUNTIES OF NEW MEXICO, 1938. . . 39

II. SIZS OF HOLDINCS AND YALUE OF PROPRRT,

EL CERRT TO, NEV LEXICO, 1940 . . . . . . . 64

III. NUABER OF SPECIFIED LIVESTOCA OWNED BY

FAMILIES OF E CERATPO, NEW MEXTCO, 1940 . . 67

IV. NUUBSR OF CHILDRIAN WHO WERE REPORTED AS

HAVING DIED UNDER 5 YTARS OF ACE, EL CERTIT, MEII MBXICO, 1940.........

จ. SOCIAL PARTICIPATION OF FRABS OF FAMILIES,

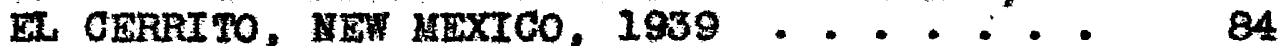

VI. AGE AT MARRTAGE OP UALE AND FEMALE HEADS OF HOUSEHOLUS, EL CERRTT, NEW MEXICO, 1940 8?

VI. GRADES IF SGHOOL COMPLITED BY MALDS AHD FEMALES, ABOVE 15 TEARS OF ACE AND NOT ATTEHDIHE SOHOOL, OF H. CERRTTO, NET MEXICO, 1940 . . . . . . . . . . . . 92

VIII. AVERAGES FOR SPECIFIED ITEM, II CERRITO,

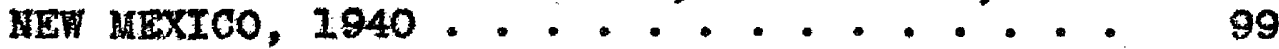




\section{LIST OF FIOURES}

PGTRE

PAOR

1. Loostion of houses and bullalngs, $F 1$ Cerrito, Nev $\operatorname{Mex} 100,1940 . . . . . . . . . . . . . .332$

2. Pereentage alatribution of Spanish-gpeaking people of Nen Hexteo, 1938 . . . . . . . . 38

3. Opper Peoos Tatorehed showing looatlon of prine ipal villages, $1939 . . . . . . . . . . . \quad 42$

4. Ownerghip of Iand for Townshlp 12d, Range $16 \mathrm{E}$, Hen Hexico, 1940 ................ 68

5. Distribation of the total population of New

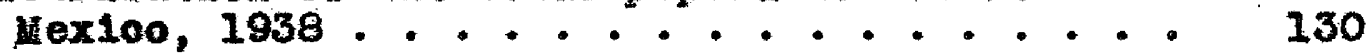

6. Strip-holdings of land in the village of La Questa, Hew Mexico, 1940........... 136

7. Strip-holdings of land in the vilage of Cerro, Hew Kex100, 1938 ............... 13?

8. Imrigated holalngs of El Cerrito people, 1940 - 147 


\section{ABSTRACT}

This study is an atterpt to determine the influence of the Spanish and Mexican land grants upon the soclal organization and soolal processes of the people in a rural, Spanish-Anerioan village of northern New Mex100. To some extent, the study also reflects the influence of the grants upon a much wider area, that covering rome ten counties in the north-oentral part of the tate and frequently referred to as the "Spanish-American area."

Two main sources of data were used in this study. The primary data were seoured from an intensive survey of a Spanish-Are rican village in the western end of San Miguel County, New Kexico. The secondary data, dealing with the nature and history of the Spanish and Mexican land grants, were taken from records of the General Land office, varlous governmental records and from the few individually complled and publiahed works which deal wi th the New Mex100 land problem.

The original Spanish and Mexican land grants were characterized by extensive s1ze, a careless and often complete lack of eurveys, poor and obscure titles and a total dieregard for definite boundarles. Lands were classirled. Into two main groups: the common or grazing Iands whlch were 
rested in entire settlements and the irrigable tracts which were distributed and assigned to individual families.

W1th the occupation of the New Mexico territory by the Onited states there began the compliosted process of super1mposing an entirely new land system based on definite t1ties, surveys, and boundarie on the existing one. The result has been an enorwous loss of land to the SpanighAmerican people because of their inability. to produce sdequate evidence for the legal Justifloation of thelr olatme.

The original nature of the Spanish and lexican land grants was conduclve to the development of a few coonomioally powerful famillee who were able to doalnate Spanish-American 11fe through control of the basio induetries of the area, cattle and sheep. Th1 group ocoupled the top position of the soclal pyramid. At the bottom of the pyramid were the poons and government sponsored colonists who oame to form the laboring group for the upper class. There were few families in the intermediate or middle-class category.

W1 th the lose of these common or grazing lands from court decisions and 11tigation the Spanish-Amerioan social pyraid rapialy began to flatten out. Social distances all but disappeared after the wealth of the patrons declined to a level little above those who had once werked for them. The one resource these people have been able to cling to is the numerous, small, 1rrigable holdings which were 
speolficaly distributed to Individual families who have managed to retaln them.

The history of EI Cerrito ep1tomizes to a remarkable degree the history of the entire Spanish-American area. It 18 ol tuated on an original Spanish land grant and the present inhabltante of the village are descendants of the original granteos. For alnost a century the people vere 1ndependent and relatively prosperous. There was adequate land to oupport the combination enterprises of stook raising and sall-bcale 1rrigation farming in the valloy.

Fith the oecupation of New Mexico by the Un1ted states, bowever, the economic base of the village raplaly began to disintegrate. Lacking olear title and definite boundary Iines to the grant Iands, characteristic of the Spanish and Mexican land gyatems, the common or grazing lands claimed by the people were removed from thelr use and added to the publ1c domain. All the land the people were able to retain were the miniature, 1xrigated holdings around the village to whloh the Individual families had been fiven separate title.

Today the people of El Cerrito are still living in their village but they no longer are relatively independent group, supported by theix om economic resources. Inatead, like the Spaniah-American area as a whole, they have come to be a type of ceasonal, migratory, farn workers roaming 
the surrounding states in search of farm and other enployment so necessary to supplement the 11 ttle food that can be grown on the small, irrigable tracts of land in the village to which they still retain ownership. 
CHAP TER I

INTRODUCTION

Nature and Purpose of Study

This study is an attempt to discover the extent and nature of the relationships between the Spanish and Hexican land grante of New $19 x 100$ and the soclal organtzation and processes of the people who live on the land. Since 1 t is assumed that the present situetion, as it exists in New Kexico, is a product of what has gono on in the past, the approach to the problem has been somewhat historlcal in that the more signifloant changes in the New Mexioan land situation are described from the time of the early Spanish settIements to the present.

The maln objectives of the study may be 11 ted categorlcally as follows:

1. From avallable cecondary sources to determine the orlginal nature of the Spanish and mexican land grante and something of the history of change in the nature of these grants Prom the time of first Spanish occupation to the present, wh thecial emphasis upon New Merico. It was assumed that this should involve such factors as: type of grants allowed, rules and regulations governing the granting of the lands, subsequent changes in these rules and 
regulations, the tability of tenure on the grants, and the effects of the impact of change brought about by the acquisition of the territory by the United states in 1846.

2. Study the social organization and processes in selected Spanish-Amerioan village situated on an original Spanish or Hexican land grant.

3. To bring together the knowledge gained in these firgt two ateps in order to discover and demonstrate the ways in which the land grant has affected the social organtzation and social processes in the village studied.

\section{Scope of the Study}

The scope of this study is linited in its general aspecto to the Spanigh-American area of New Noxico in general, In 1 ts more specific phases to the Upper Pecos Watershed of the state, and in 1 ts most detalled particulars to the community of El Cerrito. The location of these geographical and cultural areas and the village of $E 1$ Cerrito are shown In Figures 2 and 3 . For a plan of the viliage of El Cerrito, which was studied intensively, see Figure 1.

several criteria were selected for choosing the village for intengive study. They were:

1. It must be whin the 11 imlte of the predominantiy Spanishspeaking area of New Mexico.

2. It must be at some considerable distance from any elty or town that might have tended to influence it unduly. 
3. It muat be altuated on an existing or original spanish or fexioan grant of land.

4. It must exhiblt certain characterigtios of the SpanishAmerican area in general, euch as: Iimited land holdings, a combination of the enterprises of farming and atock-raising, a heary dependenoe upon outside wage work, and above all perhaps, eridence a retention of old Spanish custom and tradition. These were the criteria previoualy set up to determine the boundartes of the Spanish-American area. ${ }^{1}$

After careful scrutiny of many rocords in New Mexico and numerous contacts with a wide rango of technicians and governent officials in the state 1 t was decided that the village of D cerrito, located in San Mlguel County, would be an adequate cholce. Upon examination, this village was found to weet each of the criteria for selection mentioned in the paragraphs above.

The time interval covered by the otudy is roughly from 1794 to the preaent w1th special emphasis on the year 1940 when the survey data for El Cerrito were Eathered. The author spent from February 1, 1940, to September 1 of the ame year in the village. Several return visits were made curing the year 1942 for the purpose of cheoking spectfic points and seouring additional facts. Contacts with the

$1_{\text {Soll }}$ Conservation Service, San M1guel County V11lages, Albuquerque: U. S. Department of Agriculture, 1938 ; aI80 Tewa Eagin Btudy, 1939. 
v11lage have been maintalned, by means of correspondence, from 1942 until the present time, Apr11 1943.

Although the bulk of the data gathered were supplied by the Inhabltants of the village of El Cerrito, it is belleved that the reaulta may be projected 1 th reasonable degree of accuraey to Inolude the Spanish-American area of the state in general, and the upper Pecos Watershed in particular. Th1s assumption $2 \mathrm{~s}$ based on the faot that an unusually high degree of unifomity and cultural homogenelty exists throughout the Spaniah-Amertcan area. The nature and degree of this uniformity is developed in detail in chapter IIT.

\section{Hethodology}

It was reoognized in the oarly stages of development of th1 problem that, to secure an adequate work1ng knowledgo of the aocial organization and processes of a village in the area, It would be necessary to go into the village for elrsthand observation. At the time the village was olected for study it was expected that it would be possible to 11 ve in the village for pertod of 12 monthe or long enough to observe the cyole of 11 fe and activities in the village over a full gear. The actual time spent in the village was approximately seven wonths. During this period many hours were spent talking with these people, beooning acquainted with their attitudes, collecting data about their opinions and reoording their onse historles.

In order to gain admittance to the ilfe of the viliage 
1t was necessary to assuse a role that would be sccepted by the viliagers. This proved to be easier than it first appeared. Upon arriving to 11 ve in the village every effort was made to diatribute the information that $I$ was "writing a history" of the village. This proved to be a popular role as most of the people are extremely proud of their history and are eager and willing to talk about 1 t.

Al though the approsoh to this probler is not primarily statistical certain figures and estimates were gathered on such factors as: lize of holdings, ownerghip of land, value of possessions, to. These figures were gathered by meang of a small schedule whloh was completed for each family in the rillage.

Other sources of prinary data were Interviews with the "old timers" in other villages in the area, with governmental officials in the town of Las Vegas, and with the priests and sisters of the Catholic ohurch in the area. Especially informative and interesting data were secured trop the priest who cerves the village of El Cerrito, a native spaniard whe has been in this country only a few years.

After primary data of these types were secured the next Btep was to asseable the data that would reveal the nature of the Spanish and Mexican land grants and their history. Th1s involved inteng1ve work upon the reports of the publ10 Land office, reporte of the surveyor General, and other works on the Public Domain.

In analyzing the data of the study the fundamental 
objective has been to discover the role played by the Spaniah and Mexican land grant as a conditioning faotor on the social organization and processer of the village studied.

\section{Review of selected Literature}

There Is a pauclty of Ilterature dealing alrectly with the aubject. The bulk of the early records such as petitions for and grants of land were destroyed in 1680 when the Indiane of Hew Mexico revolted and arove the Spentah Prom the territory. As a result the present souroes of reference are of a very general nature such as: reports of the Survoyor General to the Public Land offle Prom 1854 to 1891, 8pecial reporta of the Court of Private Land clalms from 1891 to 1905, and a 11 15 ted number of individual comp1lationg of epecial data.

The Soclology of Rural Life by Malth provided the orientation for this study, especially parto III and IV which deal wh thural social organtzation and the social processes of rural soclety. 2 phe blbilography included in the volume was also userul.

The Bystessatic Source Book in Rural Soc10logy by Sorokin; zimmeraan and Galpin was also valuable ald in gaining a general pergpective of social organization and the

27. Lynn Snith, The Soclology of Rurel L1fe, New York: Harper and Brothers, 1940 . 
social processes. 3 Part two of Volume I was particulanly helpeul in 1 ts treatment of the ecology of the mural habitat. of the literature dealing epecificaliy with Wexico the publ 10 Domain by Thomas Donaldson deaerves special montion. 4 The some 1300 pages of this rolume deal with the public land system and policles in all thelr ramiploations. This docutent 1s by far the most complete and helpful of any Jet published on the land situation, 1 ts nature and history, in New Mexico.

Another rleh source of Information was the files and miscellaneous unpublished reports of the soll Conservation Service in Albuquerque. 5 purling the period 1936-39 the Division of Human Surveys of the Soll Congervation servioe made numerous aurveys in the Spanish-apeaking areas of New Hexico and uncovered a large mass of inforation on land grants in the area, past and present. The recency of these surveys, plus the wde range of data they cover, make them

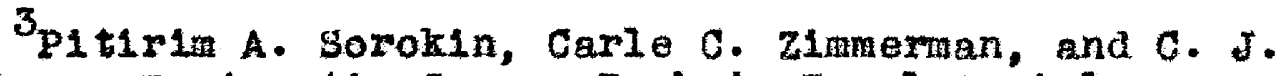
Galpin, A Sybtemat1c Source Book In Ruxal Soolology,

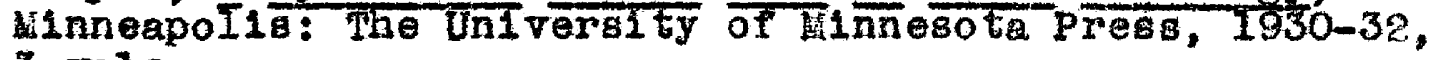
3 ro16.

4 Thoma Donaldson, The Public Domain, House Hiscellaneous Document 45, 47 th Congress, 2nd session, XIX. washington: The Government printing office, 1884.

Go11 Conservation Service, United states Department of Agricul ture, Albuquexque, New Mexico. Sone of the more pertinent studies are (1) The Tera Basin study, 1930, (2) San

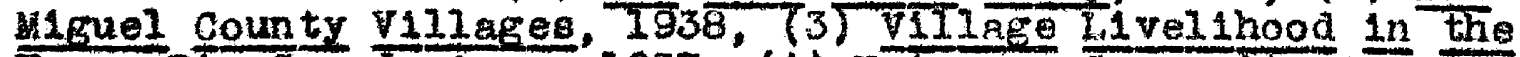
Upper Rio Grande Area, 1937 , (4) Notes on Community omed Land Grante In New Mextco, 1937, and T5T phe Partido System, 1939. 
one of the most valuable compllations of secondary data on Spaniah-American 11 fe and conditions ever assembled.

Blockmar's Spanioh Institutions of the Southwest has proven to be a rellable source of information on the early sooval and Institutional 11fe of New Mexico. ${ }^{6}$ The extremely Iint ted material published on the subject make this book a classio in 1 ts contribution to the field with which it deals. Some of the other less complete works on the subject are: Adams' H1story, Pol1t1ce, and Edueation, Dunhan' government Handout. Sanchez's Forgotten People, and Grishan's El puoblo. Other sources on the subject are IImited to casual and infrequent observations from work dealing with problems of ano ther nature.

On the history of the land grante of New Mexico alone there is no souroe of information that equals the records of the Public Land opfle in Santa Fo, New Hexico. In the files of this offlce there are dockets containing all available data, such as the original petitions, testimony before the Court of Private Land Cla1ms, etc., of more then 300 grants.

6rank Flockmar, Spaniah Ingti tutiong of the Bouthwest, Bal timore: The Johns Hopkins Press, T891.

THerbert B. Adam (editor), History, politics, and Education, Baltimore: the Johns Hopkins Press, 1890, Vol. VIII.

Harold . Dunham, Government Handout, Ann Arbor: Edward Brothers, 1941.

George I. Senchez, Forgotten People, Albuquerque: Univereity of New Mex100 Press, I940.

Glen Grishan, El Pueblo (unpublished), The Farm Seourity Administration, Amañilo, 1939. 
Unfortunately, many of these dockets are incomplete because of the lange Inoldence of loss of the old Spanish records. For 11terature dealing with the general history of New Mexico heavy rellance was placed on Twl tohell's Leading Facte of Mev Hexiean Hiatory. ${ }^{8}$ This five volume work contalns a great deal of material pertalning to the subjeot of this paper.

Another complete and readable history of New Mexico 18 Coan'B A History of Hew Hexico. ${ }^{9}$ Th1s book contains not only a chronologloal I1sting of Important New Mexican events but develops the eldelights of such events much more completely than the general run of historical documents. The chapter on Spanish and fexican Land Crants (Chapter XXVI, Vol. I), al though brief, containe a remarkable compllation of conolse data on some of the more important land grants of the state. Hew Hexico History and Civies by Bloom and Donneliy has made some contribution to the subject. ${ }^{10}$ The pirst 250 pages of the book deal rather corapletely th certain phases of New dexican history and are replete th pertinent observations and notations. It aleo contalns large l1st of blbllograph1eal references to more complete and original works.

${ }^{8}$ Ralph E. Tw1 tohell, Leading Facts of New jexican History, Codar Rap1ds: Toroh Prese, I911-12, 5 voIs.

${ }^{9}$ Charles F. Coan, A History of New Mexico, New York: The American H1storical SocIe zy, 1925.

10 Lansing B. Bloow and Thomas C. Donnelly, New Mexican H1s tory and C1vios, Albuquerque: The University of $\overline{N e w}$ Mexico press, 1933. 
Odum and Moore's American Reglonal1em contains an interesting chapter dealing w1 th the basis for setting the Southwest apart as an especially well defined reglon. Other sections of the book deel with certain concepts and derinitions used throughout this paper. ${ }^{11}$

For a comparison of the New Mexioo altuation w1th that 1n other Spantsh-speaking groups 31mpoon's The Ejido: Mexico's Way out offers $s$ ome of the history of land-man relationships In the Republic of Mexico and a falriy complete analysis of the land situation and 1 ts social lmplications in present day Mexico.12 MeBride does something of the same order for chile In hia Chile: Land and Soc1ety. 13

other less elaborate works on the man-land situation in New Mexico are also IImited. AII but a few of the boclal studies which have been done in New Mexico have all but Ignored the highly important factor of land. ${ }^{14}$

${ }^{11}$ Howard W. Odum and Harry E. Hoore, American Regional1am, Hew York: Henry Holt and Company, 1938.

12 Eyler N. S1mpson, The Ej1do: Mexico's Way Out, Chapel H111: The Univeralty of North Carolina Press, 1937.

13 G. WoBride, Chile: Land and Soclety, New York: American Geographical soolety, Research Series 19, 1936.

${ }^{14} \mathrm{~A}$ few of the more pertinent bulletins and Journal articles on the Spanish-American situation in general are:

(1) C. P. Loom1s, Informal Group1ngs in a SpanishAmerican Viliage (mimeograph builetin), Jnited Stateg Department of Agricul ture, Bureau of Agricul tural Economios, 1940.

(2) Olen Leonard and C. P. Loomis, Culture of a Contemporary Commun 1ty, w1 Cerrito, New Mexico, J. S. Department of $\mathrm{Ag} r 1 \overline{c u}$ ture, Bureau of Agricul turgl Econom1cs, 1941. 


\section{Order of Procedure}

Chapter I treats of the general nature of the problem under study and a general survey of the pertinent 11terature on the subjeot.

Chapter II is compilation of data on the general characteristics of the area and 1 ts population. These data include arailable information on: (1) The Land, 1 to topography, soll types, vegetative cover, and major streams; (2) The climate, the amount and distribution of precipitation and 1 ta adequacy for orops, pasture, and timber; (3) The people, phyelcal and cultural types in the area, their geographio and cultural origins, and something of their relationships and associations.

In Chapter III an attempt has been made to point out the important factors whioh have gone in to the making of what is

(3) S1gurd Johansen, "The Soclal Organization of Spaniah-Anertcan V1llages," The Jouthwestern Soclal solence Quarterly, rol. XXIII, 1942.

(4) Faul waIter, Jr., A Stuay of Isolation and Soclal Change in Three Spanish-epeaking VIIIager of Hew Mexico, Q Ph.D. thesis, stanford universit $t \bar{y}, 2938$.

(5) Horence R. KIuckholn, Los Atarquenos, 2. Ph.D. thes18, Harvard Unt vereity, I942.

(6) Ernest E. Maes, "The World and the People of Cund1yo," U. S. Department of Agricul ture, Bureau of Agricul tural Economics, Land Polley Rev1 ew, Harch 1941.

(7) Kalervo oberg, "Cul tural Factors and Land-Use Planning in Cuba Valley, New Mexico," Rural Boc1010gy, 1940.

(8) John C. Russell, "State Reglonal1sm in New Mex1co," soc1al Forces, 1937. 
referred to hereln as "Span1sh-American culture." Following this is a disoussion of the nature, distribution, and development of this culture together w1 th a review of the elements which 1llustrate how the V1llage of El Cerrito is typical of this oul ture.

In Chapter IV a rather detalled description is given of the soolal organization and processes of the VIllage of EI Cerrito. An intensive fleld study of this village furnishes the bulk of the primary data used to test the thesio of the paper.

In the Ifth and final Chapter the thesis of this study 1s developed, namely, that the Spanish and Mexican land grant has Deen an important factor in the conditioning of the soclal organization and processes of the village. The procedure In this chapter has been to give a brief history of the status of land distribution in New Hexico, types of land grants in the area, the significant features of Spaniah and lexican colonlzation policy, and subsequently, the radical changes In the land situation brought about by occupation of the territory by the United states. With this as background there 18 presented a dscuselon of the effects of the land grant on the cocial organization, Institutions, and social processes as found in the village studied. 
CHAPTER II

GENERAL CHARACTERISTICS OF THE AREA

The Village of El Cerrito is situated in the eastcentral portion of northern New Mexico. It is approximately at the center of what 18 generally designated as the "Upper Pecos Watershed," an area drained by the northern section of the Pecos River. The northern boundaries of this watershed reach to the crest of the sangre de cristo Mountains in fiora County. Fron this point southward it fans out considerably taking in almost all the western half of San Mlguel county, In wich El cerrito is situated, and portions of northern Torrance and Guadalupe Counties.

\section{The Land}

In generel this area 18 one of high plateaus or mesas, enuggled close to nearby mountaln ranges, valleys and arroyos. The population 18 normally clustered along the various water courses at elevations varying from 5,000 to 8,000 feet. Because of early and late frosts, land higher then 8,000 peet in the area is seldom occupled for more than a lew epring and sumer months when livestock 18 commonly pastured at these higher elevations.

The oldest and most extensive outoropping fornations in 
this watershed are members of the Mlosissipplan, Pennsylvanian, and pertian serles. These serles, comprising massive exposures of IImestones and sandstones, are the princlpal outorops in the northern and central parts of the watershed. In the contral and eastern parts of the watershed, these series are overlain by alluviuns of the quaternary period. ${ }^{1}$ The main soll types of the Upper Pecos Watershed are of the Rough stoney Land and Reeves groups. They are largely made up of light-brown calcareous topsolls which are shallow and often unsultable for eultivation. Undernesth these topsolls are the colcareous, Jellow-brown subsolls resting on cal1che or 11mestone. The absorptive power of these soils is low to medium. They are usualiy shallow and subject to wind and water erosion, except at the higher altitudes, where the vegetation is surfiolent to prevent it. Examples of this erosion are obvious and numerous even in the alluvial solis of the narrow valleys. Soll conservation practices are made diffoult by the widely scattered holding and the fact that the people have not been convinced of the value of suoh practices. Reports of studies completed and othere in progress repeatediy point out that the depletion of the grass cover crop by over grazing has added tremendously to the flood damage along the Pocos Fiver during the past two or three

${ }^{1}$ Unpublished data from the Soll Conservation Service, Un1 ted States Department of Agricul ture, Albuquerque, New Mexico, 1939. 
decades. 2

The covering in the Upper Pecos Watershed is divided Into the three vegetative types: timber, woodland, and short grass. These three areas are well defined in the watershed. The timber type 11es in the northern part of the watershed, the short grass area runs along the eastern boundary, and the woodland area, the largest of the group, is in the southwestern seotion of the watershed.

The timber type, which oong1sts largely of pine, fir, apruce, and oak, 1 s concentrated in the higher area which will range in elevation from 7,000 to 11,000 feet. The land 1a largely Federally owned. Here the grazing and logging operations have been well controlled and erosion is at minimum. Where this land is privately owned, it is cheracterized by severe erosion, cutover lands, over-grazed range, and submarginal farming land.

The woodland type 11 es below the timber area between the elevations of 5,000 and 7,000 feet. Here the timber $1 \mathrm{~s}$ Juniper, P1non, Dak and gorub PIne. Although somewhat spotted, the grass covering is supficlent for grazing cattie and sheep. Wuch of this land 1s privately owned and 1s characterized by severe erosion and over-grazing. The short grass area is somewhat below the woodand in

2 go1l Conservation service, U. S. Department of Agriculture, Pecos River Watershed, Albuquerque (unpublished), 1939. 
eleration. This land is largely rolling pratrie, and is characterized by less severe erosion as a result of its heavier vegetative cover. Large cattle and sheep ranches have absorbed most of this land during recent years. Only a fraction of 1t is farmed.

The main atream of water in the area 18 the Pecos River which divides the tershed into two very nearly equal parta. Th1 stream 18 fed largely by welting snow from the nearby mountain tops. Such sources assure an almost constant flow of water for the entire year. In to the peeos RIver flow such minor streams as the Gallinas River, and Tecolote Creek. These two latter streans cannot be depended upon for water during more than a fraction of the year.

The runoff of these streans is extremely rapid and berlous damage may be done along their banks within a few hours after a heavy raln. The average fall for the Pecos R1ver is 13.8 feet per mile. For the area of the Upper Tatershed the fall averages 67 feet per mile.

\section{The climate}

The Upper Pecos Watershed area, 11ke the remainder of the state of New Mexico, is deficient in rainfall. The amount differs according to altitude. Stations placed over the area show a variation from above 33 inches at the highest station to a little above 15 inches at a lower station some distance eron the mountains. The general average for 
the area, based on records of 15 stations, is approximately 16 1nches. 3 Fortunately for agriculture in the area the distribution of this rainfall is such that the heaviest precipitation comes during the summer months when the need is greatest.

The people of the area have come to depend heavily on the snowfall in the nearby mountains to furnish needed water during the spring and sumer. Snowfall 18 extremely heavy In the high mountains ranging as high as 300 inches at the top of the Sangre de cristo ridge. 4 This snow, in a normal year, w1ll furnish water for the river over a greater portion of the spring and summer months.

The general direction of the winds in the area, as well as for the state as a whole, is from the west or southwest unless Influenced by local conditions. During the sumer months these winds are usually molst which 18 largely the explanation of the concentration of the rainfall in this season. The velocity of these winds is relatively high, ranging up to 50 m1les per hour. The low molsture content of these winds plus their high velocity results in a high rate of molsture evaporation during the warmer months which may reach as much as 100 inches annualiy from a free surface.

3U. S. Department of Agricul ture, Cl1mate and Man, 1941 Yearbook of Agricul ture, Waahington: Government Printing OF110e, 1941, p. 1015.

${ }^{4}$ Ib1d., p. 190. 
This evaporation varies with altitude being much less as the higher altitudes are reached. 5

The variation in temperature for the area is extreme, ranging from a high of 108 degrees $F$. to a low of -32 degrees F. over a perlod of 15 years. The winters are generally cold and long. The last killing frost is generally around the Pirst of May and the first one in the fall around october 1. This allows for a growing season of approximately 155 days.

\section{Economic Bases of Subsistence}

As a result of the above factors it 1s obvious that the physical environment of the area is not conducive to intensive agriculture. Inadequate precipitation alone prevents extensive growing of orope except in areas where irrigation is possible. Largely for this reason the bulk of agrioultural production in the area is done in the small, irrigated valleys that may be 1rrigated from acoompanying streams.

Crops that are grown away from the streans are largely beans, harrested dry, and a linited amount of wheat. These cropa are usually able to mature within the short growing season and the average precipitation of approximately 16 Inches 18 sufficient to grow them providing 1 ts distribution for a partloular year is well spaced.

A much wider varlety of crops can be grown on the

5Ibla., p. 1024. 
1rrigable land of the valleys. Although wheat and com predominate there are also many other orops such as alfalfa, oats, oane and garden crops. These garden crops assume a role of Importance to the looal people that would be diff1cult to overemphasize. On a plot of land no more than $1 / 4$ acre in extent an industrious fam1ly may easily grow enough ohll1 peppers, beans, onlons and other vegetables to supply their family during the spring and sumer months.

Al though intensive agricul ture is necessarily $11 \mathrm{~m}$ ited In the area by the physical factors of soll, climate, and topography, stoek raising is profitable and possible providing anple grazing land and water are avallable. The grass in the area 18 of a short, bunch var1ety that 1 s excoedingly nutritlous and despite the rather severe winters range livestock may be kept out on the plateau or mesa land throughout the winter months with a minimum of feeding and shel ter.

Unt1l approximately the beginning of the twentieth century the agricultural base of the area consisted of a combination of toek ralaing and 1rrigation farming. A fow Pamilies in each village owned the livestock and the remainder worked for them by the day or month. All farmed thelr irrigable land in the valley for food to supplement cash income earned from the 11vestock enterprise.

Since early in the 1900's this pattern of 11velihood has changed. Pasture lands, once so abundant, are no longer 
In the hands of the village people. None of the v1llages in the area now own or operate enough land and livestock to give employment to all thelr people. Where formerly there were a dozen men in a village owning thousands of sheep each there are now only two or three with a few hundred each.

With th1s change in the coonomic base of the area the people began to seek work outslde the area. At the present time the men go as far as Utah and woming to work in the sugar beet fielda, to herd sheep, and to work in mines. It is not unusual for a man to be gone for $\mathrm{six}$ months or even a year without returning to his home and fanily who were left in the village. Thus the pattern has become one of Irrigated farming and migratory wage work. The irrigable holdings furnish a substantial part of the family's food, and the wage work provides the cash for buying whatever else the fam11y. uses.

\section{The People}

The population of the Upper Pecos Watershed is predominantly of Span1ah-American origin. 6 According to a reoent

6

The term Spanish-American is used generally thoughout the Southwest, and especially $\mathrm{New}$ Hexico, to 1dentify a group of people whose basic language is Spanish, who are of mixed Spanish and Indian blood, and who have been in the area for several generations. The term Mexican is often used to denote the same group but, as a rule, New Mexicans reserve this term for a group more recently from mexico and more nearly of Indian descent. Hereafter, this term w1ll be used to denote all Spanish-speak1ng people in the area who are not 1dentifled definitely as Indian. 
estimate based largely on school enrollment, the people of San Miguel County, in which the village of El Cerrito is located, are approximately 83 per cent of Spaniah-American extraction." The remainder of the population is Anglo. 8

The First Spanish-Anericans to settle in the Upper Pecos Waterahed area arrived in $1794 .^{9}$ They came from the upper regions of the RIo Grande RIVer, near where the olty of Santa Fe, New Hex1co, is situated. They migrated to Bettle a traot of land that had been granted to then by the Spanish government.

These early settlers were descendants of Spanish and Mexican immigrants who had come into few Mexico after the re-conquest of the texpt tory by De Vargas in 1692. For the most part these settlers seen to have been famers and sockmen as contrabted with their forefathers who were a heterogeneous lot of ex-soldiers, adventurers, and men of fortune to whom the crown of Spain Mas under one obligation or another.

In Mexico and New Hextco their Span1sh forbears had al- . ready aixed with the Indian elewents to a conslderable extent.

7 George I. Sanchez, Forgotten People, Albuquerque: The University of Hew Hexico Press, 1940, p. 30 .

8 Phis term 18 used generally in Hew Mexico to designate the group of people whose basio language is Engl1sh. It w111 be used in this paper to indicate all who are not SpanishAmerican or Indian. Hex100.

9 Publ10 Land ofr1ee, Land Grant Dockets, Santa Fe, New 
Today the racial oharacteristics of these people indicate. that a vast majority of them have varying degrees of Indian blood in their veins. Jugt what are these proportions of mixed blood in the velns of the Spanish Americans has long been matter of debate. There are some who maintain that the Spanish element is greatly predominant, al though nearly everyone admits that sone admixture had taken plaoe prior to the rigration from Mexico. 10

A search through the records of two of the oldest churches in the area falled to disclose any marriages between the Spanish-American and Indian peoples. Th1s finding was substantiated by the experience of an investigator of the SolI Conservation Service who found that "within the memory of the oldest inhabltants (of northern New Mexico) there has been, except for rare instances, no intermarriage between the Indians of the region and the Spanish-Anericans."Il Certainly. the fusion of races which produced the Spantigh-Americans took place some time in the past.

As 18 the general rule w1th native peoples and cultural. elements, the Spanish-American population of the upper Pecos watershed is concentrated in the rural areas, 11ving in villages along the several streams of water. The majority of

10 George I. Sanchez, A Study of Spanish Speak1ng Childres on Hepeated Tests, A Thes18, Austin: University of Texas, 1931, pp. I0-13.

${ }^{11}$ Boil Conservation Service, Tewa Basin Study, Albuquerque: v. S. Department of Agrioul ture, 1939, II, 11. 
these v1liages are relatively old, all but a few of which were settled between the jears 1800 and 1840.12 These settlewents were almost entirely in the Foodiand and Timber areas of the Watershed where the combination of 1rrigation faraing and stoek ralsing was most feasible.

The Anglo is relatively a newoomer in the area. One of. the firat to cone into the area to stey arrived in 1848.13 He married a looal Spaniah-Amertean girl and latex came into poseession of a slzeable grant of land. Others who came into the area before 1900 were largely of an adventurous type, some of then working for local stockmen and others dolng hunting and trading.

The majority of the Anglos now in the Upper Pecos Watershed area arrived after 1900. Some of then came to homestead the land which was slowly belng surveyed and others moved in to buy land patented by both Spanish-Ameriean and Anglo fam111es. These famliles settied in the short grass section of the area which has proven to be more adaptable to sheep and oattle ralsing. These families came from texas, oklahoma and Kansas, the majority from pexas where they had been able to sell the1r former holdings at a fair proflt and move westward where more land was avallable and at a cheaper price.

12 Charles F. Coan, A H16tory of New Mex100, New York: The Anerican Historlcal Soc1ety, $1925, \mathrm{pp} \cdot 475-79$.

13 Harold H. Dunham, Government Handout, New York: sawards Brothers, Inc., 1941, p. 218. 
The Anglo famllies did not follow the village pattern of settlement established by thelr predecessors. Instead, they - ottled in a widely dispersed pattem, often near the center of their lands. This pattern still prevalls for then today. Although the Anglo farmers own a substantial portion of the better grass lands of San Miguel County, it is concontrated in a few hands. The Extension Agent of the county estimates (1940) that there are no more than 200 Anglo farmers in the entire county. The total population of the county is roughly not more than 3,000 most of whon 11 ve in the town of Lag Vegas.

Contacto between the Anglos and Spanish-Amerlcans are at a minimua. In the firet place, the two groups are separated spatially, the Spanish-Arericans living largely in the western two-thirds of the area and Anglos in the eastern onethird. Even in the town of Las Vegas the two groups are separated by a river which divides the town into two very nearly equal parts. Host of the inter-group contacts are brought about through business interests such as buying and selling livestock, hiring out for work and, in the town of Las Vegas, through purchases at the stores which are largely owned by Anglo merchants.

Desplte the inflexible barrier that separates these two groups of people in their social activities, there is little overt conflict between the two. Over a period of several decades pattern of social adjustment has taken place which 
is generally recognized and observed, which results in 11 the overt confliot. 
CHAPTER III

EL CERRITO AS A TYPE SITUATION

The Nature of Spanish-American culture in New Hexico

The southwest has been characterized as "the least American of all the reglong" of the continental United states. ${ }^{1}$ one of the prinelpal oriterla for substantiating this characterization is the large number of Spanish speaking people in the region. According to the 1940 Population Census of the United States, the state of Teras alone numbered more than 700,000 of these people in 1 ts total population. In the four states of Texas, Oxlahoma, Arizona and Hew Hexico there were a total of $1,066,280$.

In the state of New Mexico alone, there 1 s large proportion of the Span1sh speaking people who are often set apart from the others and, as has been indicated above, given the special designation of Spaniah-Ameriean. ${ }^{2}$ In broad terma

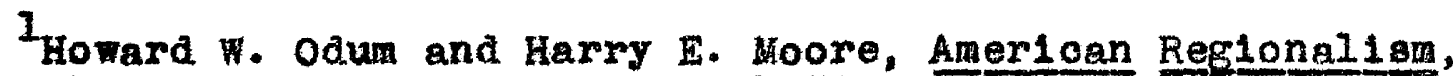
New York: Henry Holt and Company, 1938, p. 594. Although California and colorado are not included in Odun's definition of the southwest these two states showed Spanish speaking populations of 416,140 and 92,540 respectively in 1940 .

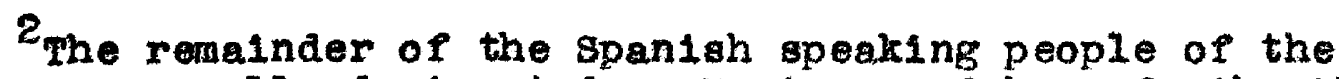
state are usually designated as Mexican and henceforth w111 bo 1dentified here by this term. 
the spanish-Americans of the state are the long-time residents of the otate, desoendants of the early Spandsh and Hexican colonists, generally considered to have a relatively high percentage of Bpanish blood, and many oultural oharacterist1es that alstingulah them from the spanish speaking people of the Southwest as a whole.

Roughly, these Spanish-Amerioans are conoentrated in the north-central part of the state, in the counties of Guadalupe, San Miguel, Mora, Taos, Rlo Arriba, Sandoval, Valencla and Socorro. To the people of the area, Mora county 18 the cul- . tural center of the area. The remainder of the spanish speaking people of New Mexico are ooncentrated in the southern counties of the state. Large numiors of these people are only recently out of Hexico and a large percentage of then drift back and forth across the border, the shifting about depenaing upon the avallability of work in New Mexico and the price such work w1Il demand.

The racial composition of the Spanish-American element In New Mexico is generally conceded to be much more $3 p a n i s h$ than the Mexican element. Although the degree of Indian blood in the reins of these people has often been a subject of controversy 14 ceems reasonable to assume that their phystcal 1solation from the rest of the world has been a contributing factor in preventing any further mixing after the people were once in the area. In addition to the Span$18 \mathrm{~h}$ and Indian elements that went into the present Spanish- 
American product there is some evidence to support an argument that early Imigrante from the United States into the area also contributed some blood to the rusion. The observations of an American traveler in the area around 1860 led him to remark:

Ah! Brother Jonathan and Mr John Bull, what becomes of your proud theory of the "extirpating Saxon" in these frontler villages? What language do these little mongrel jackanapes, these young Mexican Parthenia, speak--yours, or that of the renowned Sancho Panza? Perhap you don't understand bad Spanish. Do these poor ExIcan girls learn Engl1sh? or do their paranours rather learn Span1sh? . . . Hy brave and "enterprising" countrymen, know you not that these wretehed villagers... are indebted for their very existence to the presence of less than a dozen of you? ${ }^{3}$

As a matter of observation it is extremely prequent that one can see a person in the Spanish-American area with blue eyes and light hair. Such a phenomenon in the remainder of the state is seldon found.

The religion of the Spanish-American people of New Hexico 18 almost 100 per cent Cathol10. During the past half century some considerable converts have been made to the Protestant religlone among the Spanish speaking people generally, with the exception of the strictly Span1shAmerican element. These people are extremely devout in their religion, attend church frequently and pay the small dues which the church requires of then from time to time. The

3stephen Powers, Afoot and Alone, Hartford: The Columbian Book Company, 1872 . 
women, a a rule, are much more observant of the church's teachings than are the men.

The spanish apoken by these people has been branded as archaic and often ineorrect. 4 It is true that there are many differences between the language they speak and the Span1sh apoken in the southern part of the state or in Mexico. For example, the form trujo is generally used for trajo and many of their nouns are pronounced differently from that in other parts of the tate and eloewhere. Th1s duation may largely be attributed to the fact that 11 ttle Spanioh has been taught In the public sohools eince the occupation of the territory by the United states in 1846.

The 1111teraoy rate for the state of New Mexico is one or the highest in the nation. The united states Census of 1930 revealed that 13.3 per cent of the total population of the state could not read or write. A tudent of the area has recentig observed that "the counties with the highest proportion of Spanish-apeaking people tend to have the higheat 111 iteracy rated. ${ }^{5}$ This observation is applicable to the Spaniah-American area which contains the countles with the highest proportion of Spanish-speaking people. The reasons for the high 1111 teracy rate in the French-speaking

4 go1l Conservation Service, San M1guel county Villageg, Albuquerque, 1938 , p. 6 .

${ }^{5}$ George I. Sanohez, Forgotten People, Albuquerque: The University of New Kexico PreBs, 1940, p. 29. 
area of Loulsiana, as pointed out by Sm1th, are also applicable to this area where "they have values and standards, plenty of then, but they are not the values and standards of their English speaking nelghbors. In view of the1r many violesitudes, it is not diffioult to see why they have been low in adopting Anglo-Saxon waya, Including Anglo-Saxon sohools; and this, in turn, accounts for the fact that so many of them are unable to read and write." 6

The school system in the Spanish-American area of Now Hexico is probably the poorest in the state. Many special probleas attend the operation of the sohools in this area that do not obtain elsewhere in the state. As Sanchez has oald, the Spanish-American chllaren "come to school, not only without a word of English but without the environmental experience upon which school life is based. He (the child) cannot speak to the teacher and is unable to understand what goes on about him in the classroom. He finally submits to rote learning, parroting words and processeg in self-defense. To him, school 11 fe 18 artificial. He submits to 1 turing class hours, only partially digesting the information the teacher has tried to impart."

The Span1sh-Amerioan area of New ffexico is an area of

6T. Lynn Smtth, The Population of Louls1ana: Its Composition and Changes, Louigigna Agricul turaI Experiment Station Builetin 293, Baton Fouge, 1937, p. 65 .

7 Sanchez, op. c1t., pp. 31-32. 
villages and small farms. The village is usually patterned. according to the design set down by the crown during the t1me of Spanish domination. 8 The center of the town is always the Plaza, a rectangular plot of ground varying in extent From one to three acres. The houses are built along the sides and ends of the reotangle focing the Plaza. The houses are frequently observed to be in long adjolning rows. Th1s phenomenon develops over a perlod of time by the practice of a son, when he marries, bullaing his house on to the side of that of his parents. Sometimes these rows of houses will reach the entire length of the Plaza, an indioation of the extended age of the village proper. The church and ochool builalnge may be bullt along the side of the Plaza or else within the Plaza 1 tself. Th1s latter practioe has become quite common in the bullaing of the more recent villages. Behind the houses, and away from the Plaza, are the " barns, corrals, and sheds. See Figure 1. These facilities house the domest1c 11 vestock and the feed and grain stored for use during the winter months. Beyond the barna and corrals are the 1rrigated fields. phese flelds are usually quite close to the village the alstance depending upon the acreage of the valley floor. Still further away from the village, and on the wesa, are the dry farming lands and comon pastures.

Brank w. Blacknar, Spaniah Institutions of the Southwest, Baltimore: The John Hopkins Press, 1891, p. 212 . 


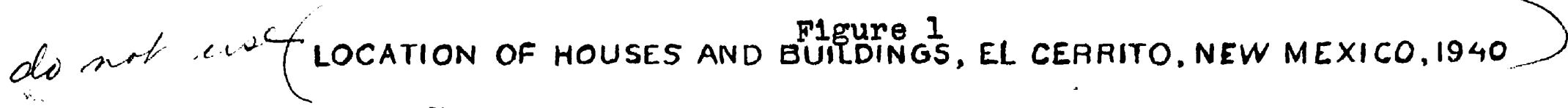

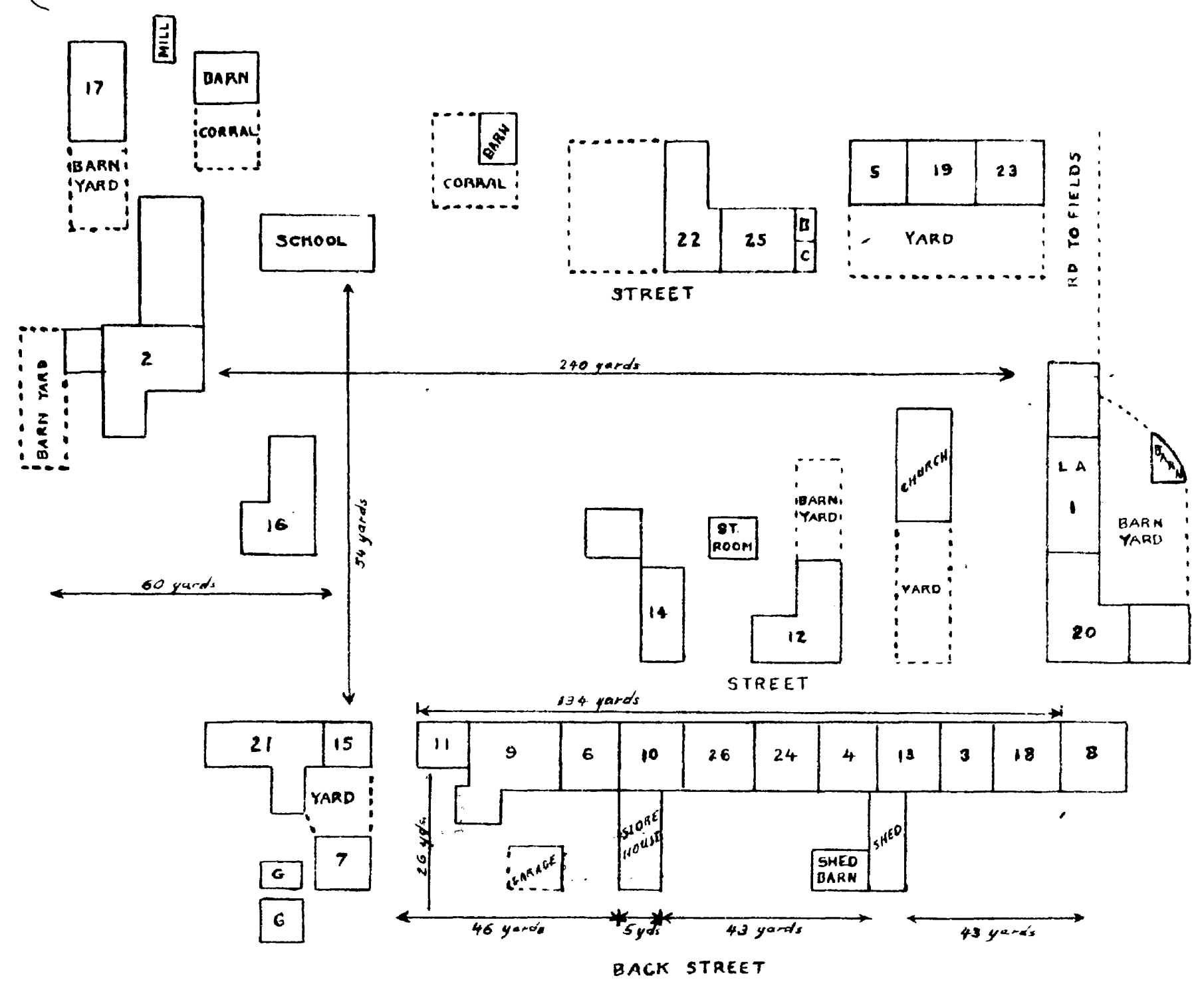

$$
\text { 7ig, 1, Pawe } 23
$$


The house type in the Spanish-Ameriean area are remarkably uniform. The typloal houge differg fron types in other parts of the etate and area largoly in 1 ts sather high. steeply pitched roofe, covered with sheet 1ron. House construction in the area is relatively good for the altitude 28 generally 6,000 feet or over and the winters geverely cold. The walls are from 18 to 24 inches thick, and are of adobe (mud and straw) construction. Both the inside and outside of the walls are plastered with a thin oheet of mud. The celling 18 of thin cheese cloth or heary paper. Doors and windows are purchased axept in a few vilages wher the doors are of heevy, thick, timbers and elaborately carved. The floors are of food or t1ghtly packed earth.

The Spanish-Amerlean area of New Hexico is characterlzed by a high degree of fam ovmerahlp. The 1940 Undted States Census of Agriculture showe that in Taos county approxinately 94 per oent of all faras in the oounty are owner operatea. In the elght counties of Guadalupe, Mora, Sandoval, Socorro, Rio Amrba, Taoa, Valenola, and San wigual, in whloh the bulk of the Spanish-American population 18 found, only 10.8 per cent of the rarms were tenant operated as compared with 17 percent for the etate as whole. Thus the farmerg of this area have olung to thelr holalngs to an extent not achleved in other parts of the tate. There beer to be two principal reasons for this. In the firgt place, these familles have long been dependent upon their small, irrigated tracta of 
land to furnish substential part of thelr food. Secondly, there are no major and costly irrigation systems in the area to tax the land as has been the case on the lower Rlo Grande and Pecos valleys.

The Spanieh-American people of III Cerrito, New Mexico, have retalned their Spanish social heritage to an extent not found in other parts of the nation. The ohlef form of amusement, namely dances, have been modifled but ilttle since the time of the early colonizations. ${ }^{9}$ The modifications that have been made are mainly the resul ts of increasing poverty In the area which has necessitated the cutting out of the many Irills and fancy costumes, the conspleuous consumption, that were once in evidence. Now, in 1800, the music for the dances is rurnished by the guitar and violin. In faot these instruments are seldom absent from any gathering end have an Impartial place in most of the homes." 10

Flestes and other festivities are still celebrated at every appropriate occasion. All villages celebrate a two or three-day affair in honor of thelr "Patron Saint." This consists of church servioes, eating and drinking, speech making, followed by the Inevitable balle, or dance. Fhls celebration 18 held annually without exception and is attended by everyone in the v1llage; and any visitors that care to come are

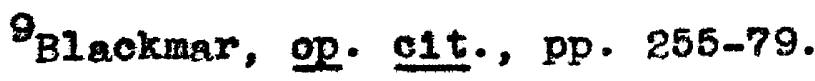

$10_{\text {Ibia. , p. } 258 .}$
} 
also welcome.

Holy week 18 another occasion on which the v1llagers spend from three to five days in the observance of special oeremonies. Since this day is a specifle church day the occasion 18 under the direction and supervision of the priest. Church services are attended from two to three times per day while the Holy Day 18 belng observed; during the perlod there is much cooking and passing of food from one house to another. It is a time too when chilaren who are away from home make every effort to return to the village.

The Spaniah-American area of New Mexico has come to be designated in other parts of the state as "Penitente Country." It is in this territory where the ancient art of flagellation 18 practiced in a number of villages during the Holy Week. At th1s time nembers of the order, who are Catholic, meet at a morada or meeting place away from the village, where they renain all week performing their rites. These are guarded by great secrecy. The climax of the ceremony is the "cruc1I1xation" of an elected "Christ." Although the ordeal is still somewhat severe, the general opinion in the area seems to be that it has been modifled somewhat during recent jears. The church has long frowned on this order but with 11 tt avall. It still prevalls in a large part of the area. "Penitente hunting" has become quite a popular sport for adventuresome Anglos during Holy Week, many of whom later express regret at having had such curlosity. 
The Span1sh-Amer1oan has borrowed heav1ly from his Indian contemporaries in New Mexico, in making his physical adjustments to the area. He has learned a great deal from the Indian in the matter of crops, Irrigetion, and a mult1tude of minor techniques for dealing with the immediate environment.

In the matter of crops, the acquistition of ch111 (peppers) from the Indians was valuable one. Th1s oh111, although extremely hot, 18 nutritlous and grows readily on the 1rrigated coil of the area. ${ }^{11}$ There are lew spanish-American familles in northern New Mexico that do not serve chili, in one form or another, In at least two of the three meals of the day. It is eaten green, dry, powdered and mixed with every sort of meat and regetable. To deprive one of these families of 1 ts chill would be considered a orime of elmost equal importance with depriving 1 t of bread. Every house will contaln one or more long strands of these pods, whose rich yellow and red colors add a highly decorative effect to the dwelling.

Another important Indian food used extensively by these people is the blue malze or Indlan corn. It $1 \mathrm{~s}$ grown exclusively for human consumption, being auch preferred to other varieties. This corn, in the hands of a skilled Spanish-

${ }^{11}$ Arthur Gose, Nutrition Investigations in New Mex100, New Mexico Agricul tural Experiment Station BuIIetin 54, Las Cruces, 1898, Chapter 1. 
American housewife, can be turned into a wide variety of dishes ranging from hominy and meal to number of cholce desserts. Tortillas, tamales and other typical dishes of the area are generally considered to be of a much htgher quality and taste if made with this type of corn.

The Distribution of Span1sh-American Culture in New Mexioo

The Spanish-Araerican population of New Mexico 18 concentrated in the north-central part of the atate. In the group of ten counties surrounding the headwaters of the Rlo Grande River 11re 170,000 of these people. 12 This is approximately $1 / 3$ of the state's total population, and a 11ttie Iess than 80 per cent of the total Spanish speaking people of the state. In all but two of these ten countles the percentage of the total population which was Spanish-American is over 75. See Figure 2. In Mora, Tros, and Rlo Arr1ba count1es the percentage was over 90 . See Table I. For the area as a whole, in 1938, all but 25 per cent of the population was Spanish-speaking.

W1th the exception of the urban populations of Albuquerque, Las Vegas, and Santa Fe these people are clustered In sall v1llages along the upper Pecos and R10 Grande R1vers

12 George I. Sanchez, Forgotten People, op. c1t., p. 30 , Count1e Guadalupe, San M1 gueI, Mora, Taos, Sandoval, Socorro, Valenc1a, Bernali1lo, Santa $\mathrm{Fe}$, and R1o Arriba. 

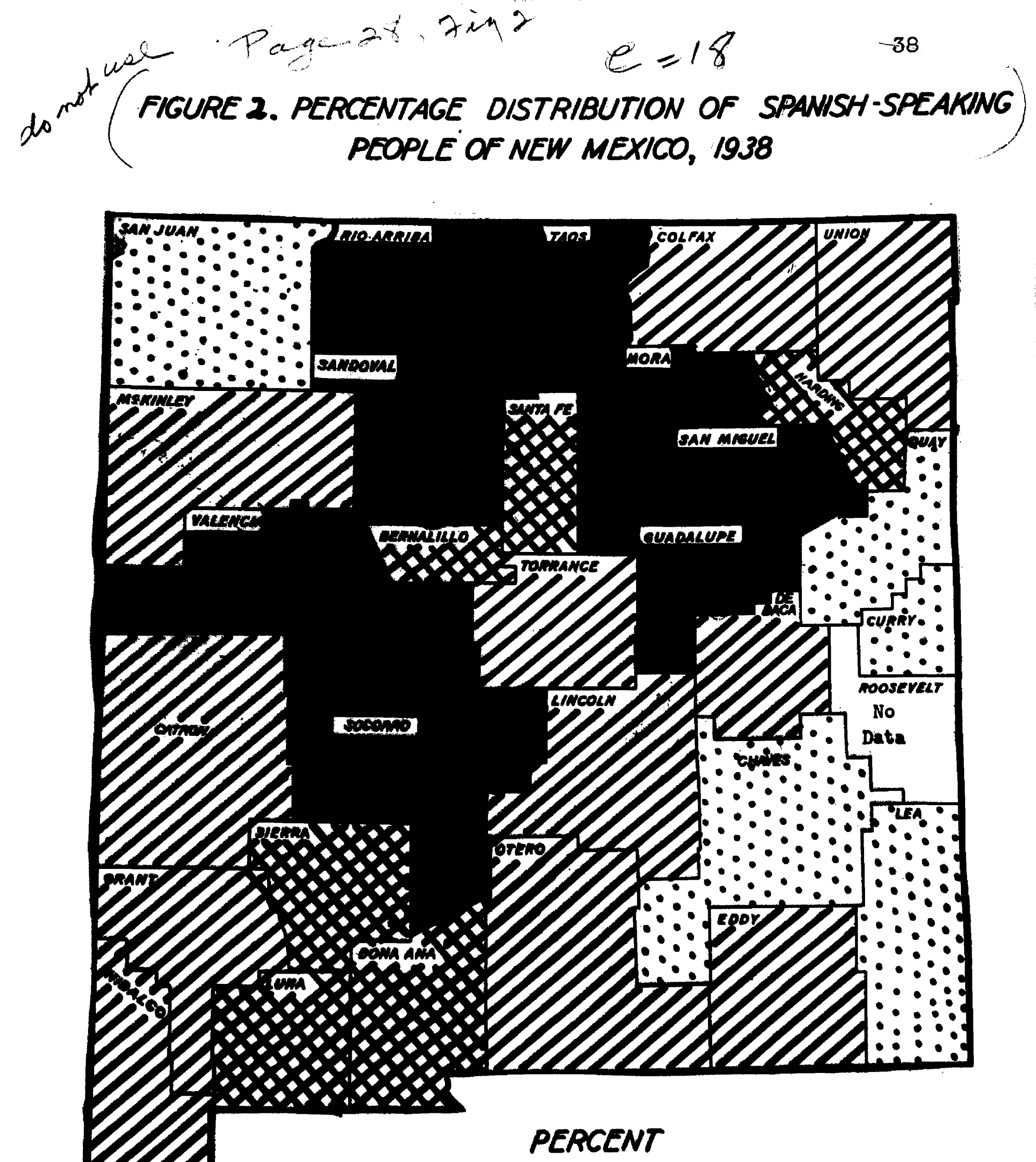

$\begin{array}{ll}\square \text { UNOER } 25 & 50.74 \\ 75 . \text { OVER } & \end{array}$

ces Ceorge I. Sunches, Forgotton People, Albuquerques Univereity of New Nexico Prese, 1940 
TABLE I. SPANISH-SPEAKING POPULATION OF CERTAIN SELECTED COUNTIES OF NEV MEXICO, IN 1938

\begin{tabular}{|c|c|c|c|c|c|}
\hline CoungY & NUMBER & $\begin{array}{l}\text { Per oent } \\
\text { :of Total } \\
\end{array}$ & COUnTY & NUMBER & $\begin{array}{l}\text { Per cent } \\
\text { :of Total } \\
\end{array}$ \\
\hline $\begin{array}{l}\text { Guadalupe } \\
\text { San Miguel } \\
\text { Mora } \\
\text { Taos } \\
\text { Sandoval }\end{array}$ & $\begin{array}{r}7,161 \\
24,992 \\
10,899 \\
14,229 \\
12,070\end{array}$ & $\begin{array}{l}85 \\
83 \\
96 \\
93 \\
83\end{array}$ & $\begin{array}{l}\text { Socorro } \\
\text { Valencla } \\
\text { Bernalillo } \\
\text { Santa Fe } \\
\text { Rio Arriba }\end{array}$ & $\begin{array}{l}10,645 \\
15,772 \\
35,202 \\
15,784 \\
23,383\end{array}$ & $\begin{array}{l}78 \\
81 \\
53 \\
67 \\
93\end{array}$ \\
\hline Total & 170,137 & 75 & & & $=$ \\
\hline
\end{tabular}

Source: School enrolinents, growth of school census, and I930 U. S. Census of Population, from Sanchez, op. c1t.

and their tributaries. See figures 2 and 3 . Thus, in brief, the total Spaniah-American population of New Mexico, w1 th the exoeption of a few wldely separated villages, is concentrated within a fifty mile radius of the clty of Santa Fe.

The Development of Span1sh-American Culture in New Mexico

The 11rst Spanish colonizing party of any permanence crossed the Rio Grande in 1598. This party was led by Don Christobal de onate and consisted of 400 persons. 13 After a elow and laborlous journey of approximately three monthe the party reached the junction of the Chama with the R10 Grande River where is s1 tuated the Indian Pueblo of San Juan.

These colonists appear to have been a motley set of adventurers and men of fortune. Avallable records indicate

${ }^{13}$ coan, op. c1t., p. 175. 
that "the colonists were not farmers and down to the surmer of 1608, even w1th the help of the laboring class, they did not 'make a crop' which was adequate to their needs." 14 As a result they 11 red off what they could secure from the Pueblo Indians of the rielnity.

Colonization of New Mexico in the seventeenth century made but little progress. However, there lo evidence that the present town of Santa Fe was settled during this period and also the village of San Gabriel. The total population of the present state of New Mextco was only 2,000 at the end of the century. 15

Al though cons1derable effort was expended by the Spanloh government in 1nducing settlers to move into the territory of New Mexico during the 18th century, such efforts seera to have had little result. The 111 fortunes of the earlier colonists in the territory, plus the eright caused by the pueblo revolt of 1680, discouraged extens1ve settlements during the century. The largest number of Spanish people in the territory, between 1700 and 1800 was 23,769 if the P1gures of the many Spanish consuses may be relled upon. The Spanish populations of New Mexico, for certaln years, during the century were given as f011078. 16

14Lansing B. Bloom and Thomas C. Donnelly, New Mexico H16tory and C1V1Cs, Albuquerque, University of New Mexioo $\overline{\text { prese }}, 1933$, p. 83 .

${ }^{25}$ Coan, op. c1t., p. 184.

${ }^{16}$ Ib1d., pp. 238, 257, $281,325$. 


$\begin{array}{cccc}\text { Year } & \text { Population } & \text { Year } & \text { Population } \\ 1700 & 2,000 & 1794 & 17,330 \\ 1760 & 5,179 & 1799 & 23,769 \\ 1766 & 10,524 & 1805 & 26,835\end{array}$

During the Mexioan regime in New Mexico, from 1822 to 1846, the rate of settlement in the territory speeded up oomewhat. By this time the American colonista had orossed the Alleghany Mountalns and were moving westward at a rete that alarmed Hexican officlals. As a result, the flexican government made every effort to establish additional colonies in the territory of New Spain. The result of these efforte may be seen in the following figures for the "Mexican" population in the territory from 1822 to $1845:^{17}$

$\begin{array}{cccc}\text { Year } & \text { Population } & \text { Year } & \text { Population } \\ 1822 & 30,000 & 1833 & 57,176 \\ 1827 & 43,433 & 1845 & 67,736\end{array}$

It is interesting to note that all of the Spanishopeaking people (exclusive of Indian) in the present state of New Mexico who were in the area at the time of American occupation in 1846 were $11 \mathrm{ving}$ in what has been designated In th1s paper as the Span1sh-American area. A map of the Inhablted places in New Mexico in 1844 shows the Spanishspeaking population as concentrated in an area within a fifty mile radius of the present town of Santa $\mathrm{Fe}$ or at the headwaters of the R10 Grande and Pecos R1vers. 18

17 Ib1d., p. 325.

18Ib1d., p. 305 . 

w1 th the oocupation of the territory of New Hexico by the United stater government in 1846 and the estrblishment of the International boundary between the United States and Mexico in 1848 (treaty of Guadalupe H1dalgo) and 1853 (Gadsden Purchase) the Spantsh-American area became virtually 18olated from the rest of the world. Contacta with other people of the United States were IIm1ted to those with varlous trading expeditions that oame into the area Irom time to time and with Mexico, to the 1tinerent 8 tragglers that drifted across the boundary at intervals in search of work. By and large, however, the 1malgrants from Mexico remained in the southern parts of the atate, in the Lower Pecos and Rio Grande Valleys. As result the southerm part of the state remained under the cultural influence of the prexicans, with 1 ts subsequent changes, while the people in the nor thern part of the state retained much more nearly the cul ture they had brought from spain. This, w1th what they learned and adopted Irom the Indians, blended into a pattern that has come to be reoognized at least in New Mexico, if not the Southwest, as Spanieh-American cul ture.

The Upper Pecos Watershed as a Spectal Area

W1 thin the larger Spenish-American area of New Mexico certain special or sub-areas may be delimited. One of these 18 the dralnage basin of the Upper Pecos River. This subarea contalns parts of the counties of Mora, Santa Fe, San 
M1guel, Torrance and Guadalupe. It boging at the headwaterg of the Pecos River, In Mora County, and extends southward to a point just below the junction of the Gallinas with the Pecos R1 ver. See Figure 3 .

Th1s area totals approximately $1,800,000$ aores about 35,000 of which are farmed. Half the total area $1 \mathrm{~s}$ contained in large land grants that, until falrly recently, were comanity owned. Now, however, these grants are largely in the hands of private, nonresident 11 vestook operators. Only about 130,000 acres are now in the hands of villages or communi ties. 19

In this area lives a group of people who are homogeneous to a remarkable degree. Almost the entire Spanish-speaking people of the area can trace their ancestry back to the PIrst group of settlers who oane into the area just before 1800 . These compunities are geographically isolated from the rest of the state by high mountains on the north and west and by long stretches of semi-desert country to the east and south. Unt1l modern roads were built through the area since 1900 It was a trek of several difficult days to reach Santa Fe, the nearest eity on the outside, a dstance of approximately 50 miles by the most direct route. Th1s made contacts with other parts of the state very difficult and occasions not enjoyed by a family more than once or twice during the year.

${ }^{19}$ So1l Conservation Service, Upper Pecos Project (unpubl1shed), Albuquerque, 1939, p. 2. 
ortginaliy this was the area of the largest 11 vestock enterprises in the atate, where one or two men from each $\nabla 11-$ lage could number their 11restock in thousands. Today, it has suffered more, perhaps, than any other area of the state from 108 of pasture and grazing lands because of the origlnally heavy dependence upon sheep. As a sudent of the area has expressed it "though they did farm the narrow valleys, thetr hope of sconomic advancement and prosperity was based upon tockrataing." 20 While most of the villages in the Spanish-American area have retained enough irrigable land to provide some cash crops the sub-area of the Upper Pecos Watershed has come to depend almost entirely on outside employment to provide the cash for their family $11 \mathrm{ving}$.

The old Spanish fleatas, balles and other activities are carried on in this area to an extent not practiced any more In the Spanish-American area as a wole. Physical 1solation from the outbide world has prevented their contacts with other people and hence has served to retard change to a greater extent than is true of the other sub-areas of the region.

These people are also set apart from the remainder of . the Spanish-American area in the thinking of the group and the other spanish-Americans outside. They are often referred

20Glenn Grisham, El Pueblo (unpubl1shed), Amar1110: The Farm Secur1ty Adrinistretion, I939, p. 4. 
to as los Manos or people of the mountains. They often refer to themaelves as $10 \mathrm{~s}$ pobres or the poor people of New

\section{El Cerrito as a Iype S1tuation}

In a broad sense, the people in the village of El Cerrito are a part of the 1,574,960 Span1sh-speaking people reported a6 I1ving in the six states of Oklahoma, Texas, Colorado, New Mexico, Arlzona and California in $1940 .^{21}$ This entire group of people may be Identifled in so far as they: speak the same language, have somewhat the same physical character16tics, share something of a common tradition, and are usually Identified by non Spanlsh-speaking peoples as Mexlcan."

The Village of II Cerrito is Identifled much more close1y, however, with some 170,000 Spanish-speaking people concentrated in north-central Hew Hexico and designated in this paper as Spanish-American. For the people of fal Cerrito are Spanish-Arerican in each of the number of characteristics used to describe the Spanish-American culture on previous pages.

Most specificaliy, however, El Cerrito 18 a definite segment of the Spanish-American sub-area previously designated as the Upper Pecos Watershed. It is very probable that nowhere in the continental United states could one find an area

\footnotetext{
${ }^{21}$ United states Census of Population, Bureau of the Census, Sertes p-15, No. 1 .
} 
that is more homogeneous in people, culture, occupation and general well being.

of the some sixty villages in the area one could hardly find any socialphenomenon in any one of them that could not be duplicated in each of the others. The physical appearance of these villages is the same with only minor variation exoept for size which may vary from a population of 20 to 200. The land holdings in each of the villages are small in size, ranging from $1 / 4$ to 20 acres. In none of the v1llages 16 the extent of avaliable land sufficient to care for the needs of the resident fam1lies. Wage work on the outside has come to be almost the sole source of eash income for all but a fel families which have been able to maintain emall herds of cettle or sheep.

Thus by examining in detall the social structure and processes of any one of the village units in the area, auch 28 Il Cerrito, it 18 possible to learn much about the general nature of society in the entire Upper Pecos Watershed. By examining only one smail comanity, on the other hand, it is possible to go into much greater datall than if an attempt were made to include the entire area. 


\section{CHAPTER IV}

CHARACTERISTICS AND DESCRIPTION OF EL CERRIMO ${ }^{I}$

\section{Deseription}

The Village of EI Cerrito 18 located on the Psoos R1ver In one of the many land pookets formed at irregular intervals where the valley has widened out euffielentiy to allow for a few houses and 11ttle irrigable land. There is nothing singular about the village of El Cerrito in the area in which it is situated. Rather it is extremely similar to a large numiber of others in the vicindty. As pointed out in Chapter III It is only one of a large number of villages where the people 11ve in the same type of houses, practloe the same manners, customs and mores, speak the same language, and have an Identical cul tural heritage.

The V11lage of II Cerrito is 30 miles southwest of the town of Las Vegas. S1xteen of these miles are over firstclass parement, three over a sem1-1mproved surface, and the

${ }^{1}$ A part of this study has been published previously as: olen Leonard and C. P. Loom1 B, Gulture of a Conteraporary Rural Coamunity, El Cerrito, New Uexico, Rural Life stuâles: I, Washington: U. S. Department of Agricul ture, 1941. Parts of this publication reproduced here are elther exclusively the work of the author or else are given special mention. 
remalnder over only a very rough and often-changed entrance to the village itself. It 1 well hidaen from the outside world. Only one familiar with the area or equipped with detalled Instruotions would be able to find it without patient searching or striking good fortune. One comes upon the v11lage suddenly if in a car. Driving over the high mesa oovered with Juniper and scrub pine, one finds the road rising abrupt1y, then tuming sharply to the right, where a panoramic view of the entire v11lage and ralley is gighted. St111 over a mile beyond and below, the houses tand out in quiet relier against the far side of the valley wall. The minlature fields stretoh out in rectangular fashion, clearly bounded by stretches of rock or the more modern barbed wire fence. Approached in winter the village seems as quiet and Iffeleas as the little cemetery just above 1 t.

As one approaches st111 oloser to the oluster of houses, almost the full length of the 11ttle 1rregation ditch that brings the water from the river to the homes and flelds can be seen. This altch 18 an engineering feat done without the ald or benef1t of modern golence. Its style of construction and the helght of 1 ts banks bullt by annual cleanings give ample testimony of 1 ts age. It 18 sald to have been bu1lt by the Indians, predecessors of the present inhabitante of the village, nany Jears before the spanish gettlers came in to the region.

Driving on a little further one crosses a new and nodern 
bridge on the Pecos River and enters the confines of the vil1age. Although there are 136 people living in the v11lage, if the driver is a stranger he is $11 k e l y$ not to see nore than a fow atragglers, mostly chlldren, in the otreets. They are a shy people when trangers appear and prefer to stay inside the1r housea and peep through or around drawn curtains to meeting the stranger outright.

Once inside the plaza one is struck by the uniformity of the village. From the center of the plaza one can count every house in the village including the comunity bullaings, the Church and the sohool. On one side of the plaza the houses are all attached together in the form of a long row. These houses are the property of the "Patron" family of the v1llage and have become a long row as the result of the sons bullaing on to the parent house when they marrled and moved to thensel ves.

The language the visitor will hear is Spanish for most of the residents speak no other. The chlldren Iearn Englieh, of a sort, In school, which 18 quickly and effectively forgotten within a few years time efter they leave the school room.

\section{History and Background}

The date of the original occupancy of the village of El Cerrito goes back well over a century. One of the oldest residents of the village was born here and says that his 
grandfather came here when he was a young man. Practically all of the fanilles are descendants of the ploneer settiers who wored onto the present site in order to be nearer their grazing lands. They came from nolghboring villages, the majority from San Miguel which 18 the parent village of the San M1guel Del Bado land grant on which the village of El Cerrito 18 located.

In the early days of settlement, cattle raising was the prinoipal economic enterprise, and the owners of the $s$ tock, by reason of their possessions, ocoupled positions of exalted importance in the community. Non-owners, and thelr fam111es, depended heavily upon them for advice as well as employment. Such men accepted this responsibility and eventually came to dominate all the affairs of the village. Dependents and incapaeitated persons came under thelr protection. Under a rell-regulated and organized system, avallable work was distributed in accordance with need to those not regulariy on the "Patron's payrol1." The only 1ndependent econonic puraut of all laborers was the cultivation of their small 1rrigated land holdings. As the local 1rrigated land was "granted" Iand and as all familles were descendants of the original grantees, each family was entitled to a small holding.

These early settlere in El cerrito found the area especially adaptable to tock ralsing. Al though the land on the mesa was poor for farming, it had a good covering of 
bunch grass. It was this abundant pasture land that Induced the cottlers to come to their new location. Part of the area had been in use by the people from San Miguel previously but Its distance from the village had prevented their making full use of 1 t.

Farming on land whioh could not be irrigated never offered a great deal of inducement in this area. A rigorous ellate and scant rainfall are serlous handicaps to such dry land farming. Ralnfall is not only meager but extremely uncertain. Al though the annual precipitation for this area ranges from 15 to 18 inohes, half of this way come within a fer days' time with no more for a period of weeks. There 18 usually sufficient molsture for planting of crops in may, but June 18 Iikely to be extremely ary, with rain again in July and August. ${ }^{2}$ This 18 the expectation pattern under which the local farmers operate.

Despite the odds against such an enterprise many of the original settlers of El Cerrito undertook part-time, dry-land farming on the mesa lands. Corn and wheat were the principal crops cultivated and for a time the new soll and favorable seasons combined to make such enterprises partially successful. But, within a brief apan of time the najority of the familles abandoned the practlce in favor of the more certain

2 Department of Agricul ture, Climate and Man, 1941 Yearbook of Agriculture, washing ton: Government printing of $\overline{110 e}$, pp. 1015-1024. 
Jobs with looal stookmen. Those who did continue to farm the mesa land ald so on a substantially reduced scale.

Beoause of these environmental factors, dry-land farming lasted only through an experimental stage. Only the 1rrigable land of the local valley proved 1 ts worth for intengive and continuous agrioul ture. This land was fertile and water from the Posos River was always avallable. Hence the people became more and more dependent upon the products of their emall irrigated holdings as basic factor in their livelihood. Mones and goods earned at wage work, plus the subsistance products grown at home enabled these families to survive in a satiafactory way. Both sources of incone were of tremendous 1mportance. The fallure of el ther to contribute meant deprivation if not near destitution.

The early econony of $E 1$ cerrito seens to have been one of plenty. Land was arallable and could be had for either the asking or the taking. Temporary depletion of the grass resource invoked little more hardship than moving l1vestock to another proximate area or spreading 1 t over a wider base. Little thought was given to the fact that some day the soll might be imporerished or exhausted. On the other hand, some effort was made to preserve the soll of the valley. The practice of spreading bernyard manure on the so11 seeras to go back well into the history of the village of El cerrito. During the last few deoades the necessity for this practice has been increasingly realized. 
Each of the two classes of land cultivated, ary and Irrigated, had 1ts own special crops that were planted year after year. The dry-farming land wos devoted to wheat and some corn, the Irrigated land to corn, alfalfa, and garden orops. Phere was 11ttle dirersiflcation. The same plece of land might be planted jear after year to the same orop. The V111age of El Cerrito 18 located on a part of the * San Miguel Del Bado land grant which once elalmed approximately 400,000 acres. Local residents place the turning point in their eoonomie stability to the date 1904 when the v. 3. Court of Private Land Clalms densed to thern all but 5,024 acres. 3 this aecision was orttioal for 01 cerrito and 1ts inhabltants. Not only ald the people lose thelr land in this ease; but much of thelr tangible and personal property wes expended in an attempt to secure a reversal of the court's decision. Only the 1rrigable land of the original grant was left to the people. 4

Although the people's grazing lands were legally taken o from then by the court's decision in 1904 it was not for a number of years later that the loss was actually felt in all

${ }^{3}$ coan, op. c1t., p. 478 , also the records of the publio Land offloe, Post Office Builiang, Santa Fe, New Mexico. These records carry the complete history of approximately 300 land grants up until a final decialon in each case was made.

${ }^{4}$ L Cezrito was not the only v1llage affected by this decision. A total of ten viliages, including El cerrito, were located on the original grant and were affected in ike manner. 
Its harshnesa. In the interval wage work had been plentiful and at a price considerably higher than the sheep and cattle men could or would pay their employ. As a consequence land became of secondary 1mportance w1 th 11 ttle thought of dependIng upon it for a livelihood when so much more might be earned at day labor w the rallroad or in the mines.

This era of prosperity lasted well into the 1920's. Howover, by 1928 wage work was extremely difficult to procure and many of the migrant workers from El Cerrlto began to debate the possibility of returning to the land. After 1930 11ttle hope remained of obtaining outside employment and a wholesale retreat began back to the villages and the lend. Al though it was generally reallzed that the land situation had changed somewhat, the returning workers were hoperul that the altuation was such that they might till their own Irrigated holdings and run few cattle or sheep on the mesa. It was not until the families were again dependent on their land that full realization came as to what had happened during the wage work boon. Now all free or grazlng land was gone. Large concerns had patented, bought, lenced, and posted huge areas, denying thelr use to the villagers. It was even forbldden that the people should remove wood for fuel, a practice to which they had long been accustomed. see AppendixA. Lany of the tracts of 1 and still remaining in the possession of the villagers were now a1stributed in such a manner that their value for use was almost negligible. 
For example, a man frow the village might own a section of land only two or three alrine miles from the center, but because of now fences 1 might be neoessary to travel ten m1108 to roach $1 t$. The honesteads that were more accessible were I1kely to be utalese because of laok of acoess to water. The owners of the new holding had been systematic In their progran of seouring control of water resources, for this, in turn, meant control of the surrounding land. In sui, the people suddenly realized that they had allowed themselves to be led into altuation from which there was no retreat. There was no longer any alternative but employment away frow the village or ald from the outside.

The changes that have come about during the last half century in and around the village are told very vividiy in the I1fe history of the oldest inhabitant. It is given below as he unfolded 1 t.

I was born in $\mathrm{El}$ Cerrito and have 11 ved here all of my life except 2 or 3 years. These years were spent in other parts of Wew Mexico whilo I was working for the raliroad and as a freighter. I owned a little property in El Cerrito all this time and thought of It (EI Cerrito) as my home.

Uy tather was a very strong and hoalthy man. I remember him very well as he ilved to be 55 years old. He was born in Santa Fe. He used to tell us many atories of 11fe in Sente Fe when he was boy. The place was very tough then and there was always danger from the Indians. He used to fight the Indians and was a very good fighter, too.

When he was very young he came to Peoos (town In San Iguel County) and worked there for a long t1me. He then moved to san Miguel and 1 t was there 
he met my mother and they were maxr1ed. When they were married he bought some land in EI Cerrito and moved there. I wag born hare in 1862 .

Hy father worked very hard and was a good businese man. Soon after he came to 1 l cerrito he bought more land (In another village some $10 \mathrm{~m} 11$ es from El Cerrito) but most of his money went for cattle. He was very well off Ilnanolally, had lots of money alwaya. In a few yeare he had several. hundred head of cattle. He used to keep money eround the house in Jars.

Iy father belleved in working hard and he made us work haxd too. Ho used to get up very early in the morning, while 1 t was stili dark. There were horses to feed and water to bring. A boy of 8 gears then was expected to be able to work all day. We worked much hardex than the boys do now. Oh, much harder. The girls worked, too, but it was for the man. The women had plenty to do around the house. There was wool to card and spin. There were clothes to meke, too. We made most all of our clo the then. It was so wuch better than now when one has to buy everything. Money wasn't 1mportant then. Everything was made at home and not bought at atore.

Al though we worked hard in those times, we used to find time for play. We could play on bad days, on Saturday afternoons, and Sunday after Rosary. We couldn't play before Rosary on Bunday. There were several games which we played. We used to take $a$ ball and toss it to one another. Used to play a Bame something Ilke golf. The balls were made by hand and so were the stloks.

My father aldn't mind our playing as long as we ald our work well. He rould never join in with us but would often stand and watch us play for long periods of time.

When I war boy many people would die and get k111ed. There was much danger during those days. then a person died the custon was for all of the man's friends and relatives to visit the dead man's fally. I alan't mind golng to those places. There was always plenty of food to eat. However, I didn't Iike the buriale. I used to get ecared when they began to throw art on the body. 
Whon I was a boy the Indians would come to the viliage at night. They would steal meat and lard from the houses. The people here always had meat and laro mado from the buffalo. The Indians used to steal tortilla too. They would bring long pointed ottoks and spear the tortilias from the windows.

One time the Indians came while ay father was taking in ox to water. They took the ox away from him and ran up into the mountains. When father came back to the village he ran to a huge drum in the village, used for warning the people against the Indians, and began beating on 1t. When the people heard the nolse they oame and went after the Indians. They finally found the ox but there was nothing left but the bones. The Indlans had killed the ox, out off the meat, wrapped it in a erape and gone away.

I went to school very l1ttlo when I was a boy. The sohool terw was short and we were taught in Spaniah. Nothing more than the catechlsm and the lettera were taught then. About all the teachera knew then was how to say A, B, C, etc.

I can remenber those teachers very well. They vere all wen and were very mean to the children. They belleved in using the whip freely. They used to make us crosa our fingers, then they would tie the fingers together and whip us. They used small leather quirts. Sometimes they would make us take oft our clothes before they began whipping us. I think everyone was too aprald of the teacher then to learn anything.

I can remenber when the church sponsored lots of Plestas and dances. Those wore good times when everyone had lote of fun. Sometimes the flestas mould last for several days. People would bring food and eat together.

When I was small a moman who was very rich 11ved here. She made lot of money frow sheep and cattle. (A member of the rival femily in the village.) she had several peons and was very mean to them. Used to have them lashed when they disobeyed her. She didn't get along very well with the people here. She would cheat them and pay then very i1ttle when they worked for her. I remember a forenan that used to work for har. Ho was a very mean but a very 
runny fellow. He was always playing gokes. He used to milk cows for her. I remember one time he milked a pall full from a cow and then sat in it. phat was very funng.

T1mes were good then and everyone had some money. No one laoked food and there was always work. There was a system here then that has died out. whe people In $\mathrm{gl}$ Cerrito used to eleot "conservator" each year. He acted as a sort of governor of the village. The people had to do whet he told them to. In those times the people would work together in planting and harvest time. The conservator would call the men to work and could determine whlch work should be done first. When someone wanted to hire a man he had to come to the conservator. He could determine who could have the job. Always he would select the fanily that needed the work most. In that way the needy were ubually provided for. In case they were not, he could ask the people for money or grain to give the "pobres." I don't think he ever had much trouble with the people-severyone did as he tole them.

Hy family wary large. There were light chllaren, four girls and four boys. When my father died we tere all IIring at home. He left the property to mother but the boys managed everything. We ald this, dividing the profits equally. This continued until my mother died four years later. Then the property was dirided into eight equal parts.

A few yeare after my mother died $a$ man by the name of $R$. came to Las Vegab. He had some money and quite a few sheep. He talked three of us boys into taking some of his sheep on a share basis. We did this and gave hin mortgage on part of our oattle. For a fev yeara we did pretty well, then came a number of very dry years in succession. We lost so many shoep that we had to give R. ome of our cattle. I lost so many sheep that it took all of my cattle to pay $R$. I lost everything that I had. I pald him though, every penny of the debt, I pald him.

After this misfortune I began to work as a Ireighter. Used to travel between the towns of Las Yegas, Tuouacar1, Santa Rosa, and Lincoln. I did this work for about 10 years. During this time I saved enough money to buy about 3 acres of the Irrigated land in EI Cerrito. There was no need to try to buy oattle or sheep again. The land around El Cerrito was taken up. I guess good times are gone from El Cerrito for good. 
The soolal and political iffe of cerrito has changed during the history of the village much as has 1 ts broader bese, the southrest. old timers in the viligge still talk of the gesterdays when Ilfe was much easier and people had time to think of something beside money and the means of getting 1 t.

There was 11ttle emphasis put on schooling in the early days of settlement. Ho attempt was made to establish regular sohools unt1l after the American occupation of the territory in 1846..$^{5}$ All attempts at educating the chilaren were Initiated by the Churoh people and carried out by the priesto or their helpers. As Blackmar has expressed it, the Spanish colonist was not zealous in bullding up a new government, in developing the resources of the country, or in providing for the education of his chllaren. As a rule, he himself was ignorant and knew little of the culture and refinement that result from educational advantages. Bealdes, had he desired 1t, there were no opportunities for 6 education, elther from books or from the world. 6

The Influence of the Church has always been great in the 11 fe of the people of EI Cerrito and 1 ts s1ster settiements. The priest has ever been the best and almost only well informed person in the village and this alone has given him treandous prestige omong his simple followers. It has

5 Lansing B. Bloom and Thomas C. Donnally, New Mexico History and Civios, Albuquerque: The University Press, 1933, p. 193.

${ }^{6}$ Frank W. Blackmar, op. c1t., p. 255. 
Iong been recognized that the local priest has been of extreme influence in all politioal elections. In $1939 \mathrm{an}$ elderly priest in the area told the writer that he courd owing the rotes of his followers toward any polltical candidate he chose. There 1811 ttle to doubt but that he was tating a lact. The influence of the Churoh in the amail, rural villages of northern New Hexico is perhaps almost as atrong today as it was 50 jears ago.

Fifty years ago, the oldsters of El cerrito will tell Jou, there were many forms of amusement in the village that no longer exist. Horse racing, corridas de gallo, " and many other types of genes were frequently indulged in. There was an annual Plesta in the village in honor of the patron satnt of the village. Friends and relatives came from 11 en around to join the villagers in their good t1mes. Marriages, ohristenings, and ang other affairs of comparable importance were celebrated in true hollday fashlon. "Religlous plays were presented during the christras ceason. Chants end hymn were an important part of church processions, of wakes, and of prayer metings. Though the visit of some official, the blrthday of a looal leader, and almilar events were often occasions for feasts and dances, the annual plestas and other rel1g1ous dates were the foundation of soolal 11fe." 8 But

${ }^{7}$ A game, played on horses, in which a buried rooster 18 recovered.

Beorge I. Sanchez, Porgotten People, op. c1t., p. 8. 
the dances were the occaslons when the peak of merriment was reached. To the tunes trom a violin, guitar, and perhaps some other makeshift instrument all able to walk without asolstanoe swung around the dance floor at a pace that would make a neophyte dizzy. As a gay old man of the village deseribed it to me, "the dances we used to have were something to remember. They would begin about 10 in the evening and last until sunup the next morning or until the wine got too strong for the lege that were carrying us. The dances they have now-- they are nothing." I 11 stened to his story patiently but after having attended several of the looal dances and trying to maintain the furloug pace they set unt1I 3 o'clock in the morning, I had difloulty belleving all of 1 t.

\section{The Land: Ownerghip and Use}

Land in El Cerrito, as in most Spanish-American vilIages in the ares, falls into two major olasses with mod1flcations of each. They are:

1. Irrigable land

a. Farm land

b. Residential loto in the village

2. Dry or mesa land
a. Cultivated
b. Free grazing land
c. Restricted grazling land 
The Irrigable land attached to the village of El Cerrito 18 Iindted in extent al though each family elther owns or is In line to inherit a amall plot. Unfortunately, only few have holdings sufficiently large to Justify full-time farmIng or stock rassing.

Th1s Irrigable land 18 prized highly by the people of Il Cerrito. very 11 ttle of it has ever been sold and then only to enother resident of the village. This land 18 orig1nal grant land and has been handed down from parents to chilaren for generations. Al though the traots are gmall (see Table II), this land 18 fertile and furnishes a considerable portion of the owner family' food.

The residential lots are also on original grant land and have been Inherited. These lots were, for the most part, marked off at the time the village was settled. Ang peraon born or otherwlie ooming into the village later, however, could still lay claim to a lot providing he could estabilish relationship with an original grantee or could gain the approval of the Board of Trustees set up to administer the grant 1and.

The dry or mesa land 10 much less valuable than the irrigable land and has never been greatly desired by tho villagers. Only a few of the familles have ever taken the trouble to increase their holdings by patenting or homeBteading additional land.

As Table II shows, most of the families own oome dry 
1and. Some of this is usually farmed to boans or, if it is favorably located, to corn or wheat. As a rule, however, this land is not profitable for farming purposes because of the low rainfall in the area. Perhaps once in flve years the ary land $\mathbf{1 1 l}$ produce a falrly satisfactory yield.

Table II. Size of Holdings and Value of Property, El Cerrito, New Hexico, 1940

Number
Reporting $\frac{\text { Amount Reported (acres) }}{\text { Rotal : Average }}$

Land ownership:

No Land Omed

Land omed Dry lana Irrigatod Iand
1 18*

14*

14

18*

18

20

$\begin{array}{cc}0 & 0 \\ 2088.0 & 116.0 \\ 2070.5 & 172.54 \\ 23.25 & 1.66\end{array}$

Value of Property

Land and bullaings

Land only

House oniy
6267.00
4622.00

2445.00
348.00

231.00

122.00

\footnotetext{
Excludes two owners who respectively own 1,292 and 2,000 acres of ary 1 and.

Por all 20 families who own ary land, the median owned 1842 ecres.
}

There 18 aetually no eree grazing 1 and in the area but there are several aections of public Domain near fil cerrito that may be grazed without protest. AB might be imagined, this land is of the very poorest quality and any grazing benefits from 1 t are negligible. Its chief value to the local people 18 as a source of flrewood.

several large tracts of land in the immediate vicinity 
of Cerrito have come into the hends of nonresident owners, and other traots have been donated to the public school Systen of the state. This land is normally rented or leased to private toekmen for grazing purposes. The one large sheepman of EI Cerrito has one school section and three sections of privately owned land leased for short terms. This Iand, however, is not avallable to the extent that it once was. Large sheep owners in the area have bought heav11y of this grazing land with the result that little is now avallable for other than owner use.

The aeute land shortage in the area began in 1916 when local tomshipe were flrst surveyed and opened to homesteadIng. As this process went on, the boundaries of the Iand avallable to the people of El cerrt to gradually were drawn 1n. Some of this land was howerteaded by the villagers but most of the patents were sold almost as soon as they had been cleared for title. Figure 4 shows the manner in which the people of El Cerrito have been enclosed and the extent to which the land bordering on thelr 1rrigated tracts are owned by outsiders.

Actualis the situation is much worse than Figure 4 indieater. Much of the dry land the villagers now own 1s of the poorest quality, often extremely rocky with no holes or streans of water. A few of the tracts are almost inaccessible because of steep hills, arroyos or long stretches of fence that muet be skirted. 


\section{Techniques of Agrioulture}

The agrioultural techniques and preotices in this area are archale. Sons have truly followed in the footsteps of thelr fathers, and thelr sons, in turn, have followed after then. An early gettler, returning to Fl cerrito today, would find 11ttle change in crops grown or in the methods of cultivating and harresting. Beans, com, and alfalfa are planted year after year, with infrequent rotation. The one pronounoed orop change has been the substitution of beans for wheat. Older residents claim that much more wheat was grown in the past when "rainfall was heavier and wheat llour diflicul to buy." Only two local fanilies are still growing wheat. All other fand11es regard bean orop more 1mportant. They are more likely to produce 1 th oont rainfall and will add more to the fanily diet. It is more conomieal and desirable to be whout nour than to be without beans.

The type of l1vestock kept is far below standard. Hogs, cowa, and horses are of a scrubby, yet hardy breed, usually poor and carelessly tended. Fer attempts have beon made to 1mprove the v111age'g 11 vestook. The villagers seem to prefer what they have and easily find rationalizations to justify their preference. Little information as to the advantages of better stock has been avallable to them, and any attempt to introduce such atrange 1deas would Iikely meet with some resistance. One of the local stockmen was persuaded to try improving his herd of cattle oeveral years ago 
with 11ttre auccess.

Not only is the I1vestock owned in 21 Cerrito of a poor quality but it is extremely Iimited in numbers. See Table III. There are more horses and mules in the village than cows. The eeven cows owned are inadequate to oupply more than a emall fraction of the dalry producte the poople would need for a gatiafactory diet. In faot, very ilttio milk is arukt even by the swall children. Instead, it is to a large extent passed around to the nelghbors for use in coffee and, to a I1mited extent, in cooking. In brief, acide from the two large ownere in the vilage, 11vestock has come to play only a sinor role in the eoonony of these people.

Table III. Nuber of Spec1f1ed L1 vestock owned by Famil1es of El Cerrito, New Hexico, 1940

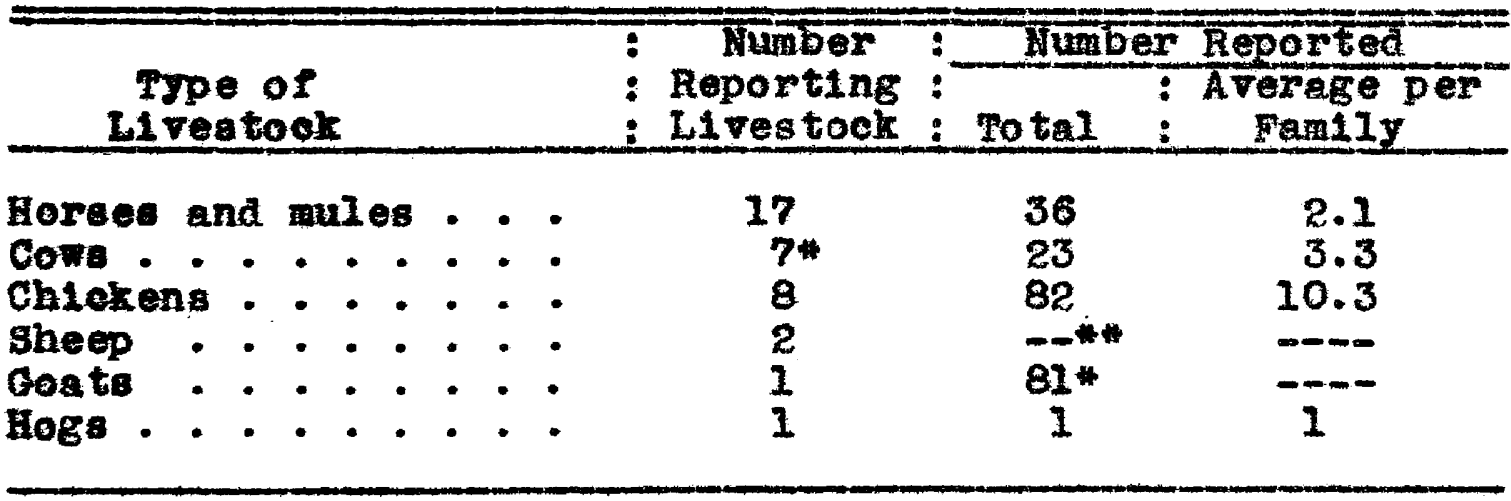

- Ifxoludes 2 omers of large aoreages who respectively reported 25 and 30 cows. One of these also reported 500 head of sheep and 81 goats. 2 head.

* Besldes one large owner only one family had sheep--

The same things could be sald of the1r poultry. It $1 \mathrm{~s}$ as mixed as it likely could be. Seemingly, the people 


$$
\text { Page }+97-74
$$

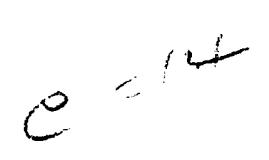

do ntwe

TONNGMIP IRN, RANGE 15E, NEW MEXICO

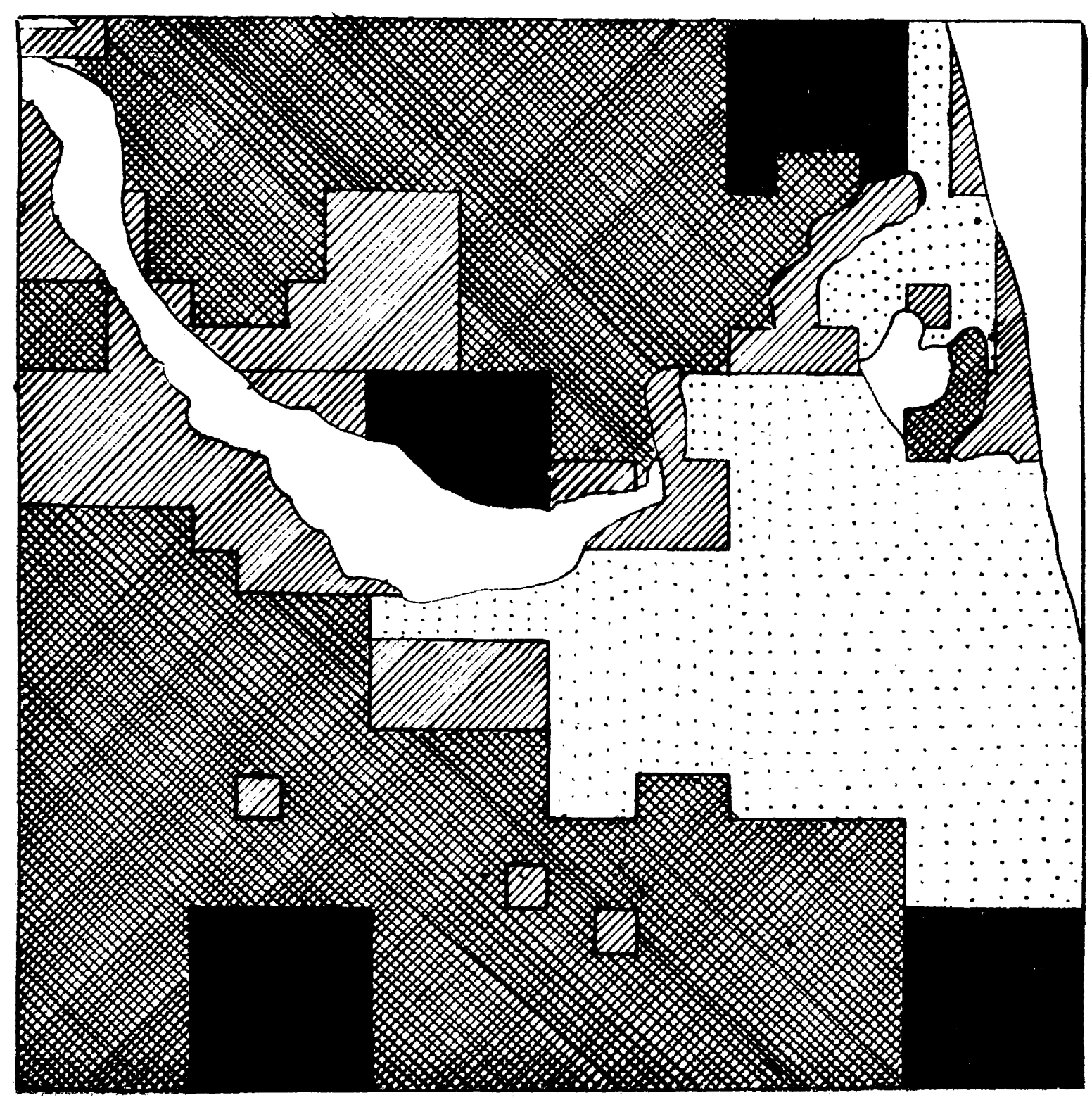

$$
\begin{aligned}
& \text { LEGEND }
\end{aligned}
$$

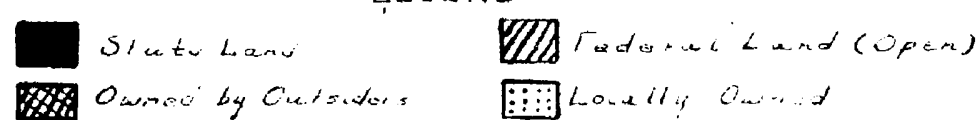

Darasi land 
net ther keep then for meat or the eggs they 111 lay. one of the elderly women of the village informed me that she never ate one of her chickens and that they very seldon layed an egf. To the question of "why do you keep themp" she answered, quite simply, we keep them for househola pets."

It is probable that better I1vertock would not reoelve proper care and treatment. Shelterg are not avallable, even during the severe parts of the winter wonths. No one would think of ealling a veterinary if a cow or horge should become alok or 1njured. Nat1ve stock 1 treated with home remedies that require only the almplest of ingredients such as lard, salt, or native herbs.

The farm equipment and machinery used in this area are of the elmplest kind. Large machinery 18 nelther used non apprectated. A horse, a ten-1nch turning plow, and few hoes and pitchiork make the standard equipment of a farm. The plow is used to turn the s011, plant the crop, and cultivate 1t. Meat and beans are threshed by hand w1 th the 1lall. If the crop 18 large enough to juatiry 1 , horges or goats may ald in the threshing by walking back and forth on the grain unt11 it becomes geparated and settles to the botton of the pile. The grein 18 cleaned by neans of winnowing. Fomen and chlldren help in this farm task.

Alfalfa is the bole crop that is not harvested by hand 
tool.. Two of the families have horse-drawn mowling machines which out nost of the alfalra in the valley as custorn work. The owners of the machines are given a portion of the alfalfa or 1 ts equivalent in labor as payment for cutting 1 t. Cash is never involved in the exohange.

Plowing and planting operations begin in lato May or the early part of June. The date may vary from two to three weeks, depending upon the milaness of the season or the quantity of molsture in the so11. The two operations are usualy carried out almul taneously. As the soll 18 being tumed the seeds are dropped into each third furrow. The v111age has only one planter. It $1 \mathrm{~s}$ a walking planter, pulled by one horse and capable of planting one row at a time. The owner 18 regarded as the most nodern fazmer In the village al though he recelved some critiolam for his investments in more efploient tools. The people feel thet time and labor are of minor value. Effletenoy and time saving mean little where already man power 18 far in excesa of the work to be done.

Intensive oultivation of orops beging in the latter part of June. Beans and corn are plowed from three to flve times, depending upon the reinfall and the number of times the land 18 1rrigated. The crops are weeded and thinned when, according to local atendards, these operations are necessary. These takk fall to the boys, alded at intervals by the father. Alfalfa, which besldes harvesting requires 
about three 1rrigations in spring and aumer, entalls less labor than any other orop grown on the 1rrigable land. It 16 ubualiy re-seeded only once in each plve to seven years. The 1rrigation system in use by the many vilages along the Pecos river in New Mexico is an old one. No one in El corrito remembers when it was built. However, there is oongiderable eridence that 1t was built originaliy by the Ind1ans. The present course of the altch has been unokanged for many years. Evidence of this is round in the many feet of bank that hove been bullt up by ennual oleanings. Even In places where construction of the attch would have neesBitated removal of only a fer peet of alrt, the helght of the lower bank has risen to ten feet or more. The madre acequig, or main altoh, 18 silghtiy less then two miles long. It beging at a bottle-neck part of the river where a crude dam has been bu1lt. Th1s dam was construeted by laying a Iine of 8 tone across the river and stacking brush and long poles behind 1t. In this way the bed of the river, above the dan, has been ralsed a helght of approximately $81 \times$ reet. This added elevation enables the water to slow out into the main ditch and on to the valley land below.

The conetruction of the dam 18 guch that there 18 11ttle asaurance of 1 ts permanence. Any big plood or unusual flow of water may destroy the entire structure. ${ }^{9}$ No

OIn 1935 a heavy rain in the Upper Pecos Waterahed destroyed the local dam completely. Before it could be replaced crops were burned out resulting in a total orop loss for the year. 
provision 19 ado for diversion, hence the dam must carry the weight and prossure of any quantity of water that happeng to come against 1t. If the preagure is too great, the dam is destroyed, as are the crops below which are dependent upon 1t. Before it can be restored lack of water has posstbly kilied the erops in the valley.

From the dam the main ditch me along the river, but the fall in the ditoh is less than in the river, so that at the entrance to the valiey it carries its water nany foet above the surface of the river. This maln ditch, and Its omaller tributaries, are malntained and repalred comanally by the users of the water. The organization for oarrying out these tasks is one of the most highly integrated and effiolent in the community. Its ohlef functions are carried on by a mayordosgo, or alteh boss, who supervises all work on the ajstem, and comittee which is responsible for all rules governing the use of the water. Each user must contrlbute labor on the altch in proportion to the amount of Irrigated land he operates. The offlcers are elected annually by the people. There $1 \mathrm{~s}$ geldom an occasion for Interference or aupervialon of the use of the water. Water is plentiful, so 1 is avaliable for anyone needing it with nerer a walt longer than two or three days. There are no intenge and extended seasons of farm labor In 51 Cerrito. Al though such tasks as planting, cultivating, and hervesting require a fow days of intense effort, they 
are soon over and the famer is again able to distribute h1s time and labor over wide variety of tasks. A PuIl day' labor during the buslest season 18 gpiced with periods of relexation. Although the worker may rige eaxly and go about feeding and caring for his domebtic livestock, there is no hurry at breakfast time. After breakfast and a brief planning of the day's work, he 1 s off for the fleld until 11 or 11:30. The noon meal consumes a good half hour, followed by one or two hours of slesta. The afternoon's work in the field assumes the same tempe. The farmer is usually back home when the sun 18 atill high for supper and to do the erening chores around the house. He attends to the horges and the cow, if there 18 one, after the evening meal is over. Throughout the day he has had time for brief chats and frequent exchanges of advice wth passing triends or relatives. In brief, there is 11 the ruahing brought about by time or season. Caring for the average local farm unit necessitates 11ttle haste. One is able to choose here between a slow tempo and a more complete use of time. The native usually favors the former.

Heal th and Medical Faollities

Several reeent btuales in the Vleinity of El cerrito emphasize the poor heal th and sanitary conditions of the 
people. 10 Fater for family use 18 taken from the $r 1$ ver or irrigation ditoh to which all ilvestock have sccess. In any cases the sanitary facillties are located in such a manner that their dralnage flows into the river. As a reoult epldemice may oweep the entire village, as well as others in the vioinity, within a rery short time. An attempt has been made in recent years to get the people to bo1l the1r drinking water but with 11 ttle success. Most of thear $\mathbf{1 1 1}$ say that "the water doesn't taste good after it has been bollea."

It is extremely seldom that a doctor is called to attend alok person in El Cerrito. The distance is too great and the cost prohibitive. It 1 s probable too that the native superstitions of the people would occasion considerable distruat of the doctor's modern means of treating s1ckness. Instead, they reiy on home remedses and some patent medielne. ${ }^{11}$

All matemity oage in the village are attended by midwives. There 1a no mawle in El Cerrlto but there are two in the nearest 711 age to $\mathrm{g}$ cerrlto. These midwives

${ }^{10}$ gee Sanchez, op. c1t., pp. 66-67; San Miguel Rural Counc1l, A Survey of V1lianueva, Las Vegas: Highland Unt-

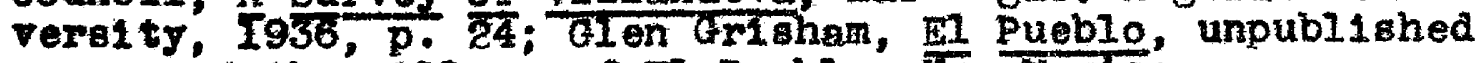
eurvey of the village of El Pueblo, Ner Mexico.

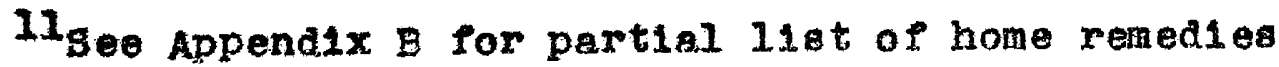
ueed in $\mathrm{m}$ Cerrito. 
are highly regarded by the local people and can be called In for a nominal charge. A few of the younger men of the Tillage expressed a preference for a tralned doctor's services but added that they could not afford the regular doetor's ree.

Many of the infants born in EI Cerrito die within a fow weeks or months of their b1rth. It 1 s nothing unusual to learn that a comparatively young married couple has lost one or wore of their chlldren at an early age. A large per cent of these deaths oscur under s1x months of age. As Table IV shows, once a ohild born in $g_{1}$ Cerrito has attained the age of one year he has a good ohance of 11ving. S1xteen of the ohilaren reported as having aled under five years of age were under $1 x$ months of age. It 18 very 11kely that all of these deathe were not reported. Several of the older fallies had diffieulty in remembering whether one, two, of three of their children had died.

Table IV. Number of Children who Were Reported as Having D1ed Under 5 Years of Age, Eil Cerrito, New Hexico, 19 ino

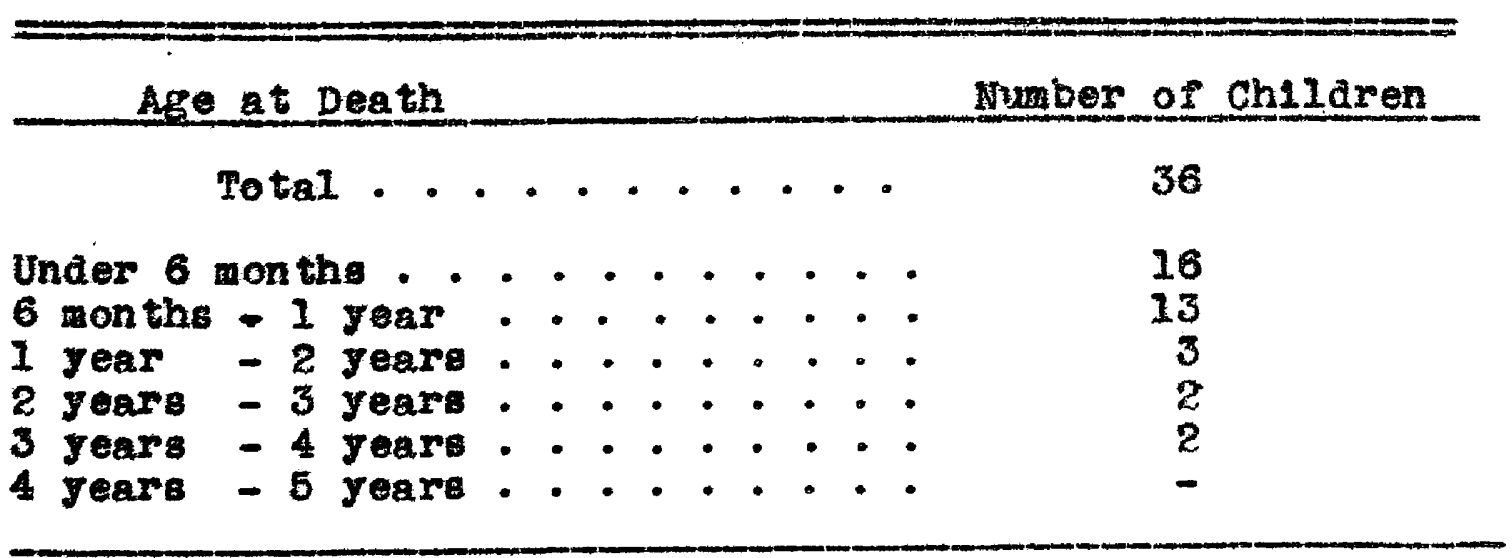




\section{Reareation and Amusement}

As in the past, Indieatod above, there are few forns of amusement or recreation in El Corrito that are not assoclated with the Church. No games are played by the adults In the village, and the games played by the chllaren are slaple and usually "homespun." A few of the older men spend a few days exch sumer fiehing al though this activity is practlced more for meat than for sport.

The one form of recreation generally indulged in and enjoyed by everyone, old and young alike, is the dances or the balleg. These dances are held almost every Saturday night and often during the week when the people are less busy with thelr crops or outside work.

These dances are attended alaost exclusively by local folk, and the music 18 always home talent. The musical Instruments are: a violin, a guitar, and infrequently an accordion. The mus10 is largely old Spanish tunes such as the raspa, the varcoviano, and others of simliar rhythm and tempo. During rocent years there has been some influx of modern Anglo tunes but the native people, as a rule, do not appreclate then.

There is little variation in the manner in which these dances are conducted. There is an accepted procedure in initiating them whioh is never deviated from in the olightest. Thus, as 18 true of so many other phases of the 
peoplo' 11ves, the asnces long ago asaumed a pattern that hes becone ccepted and about which there 18, seemingly, no deaire for ohange.

The first step in promoting a local dance is the se-. lection of a sponsor. Such a person may be requested to sponsor the dance or may do it on his own inftiative. He is usually an unmarried boy with enough money to pay the small costs. Such costs include a fee (25 cents) to the local Justice of the Peace for granting a permit and enough gasoline to keep three gasoline lamps burning through the greater part of the night. In ease the eponsor does not have an ample atock of his own vintage the costs may also Include a bottle of wine for each of the malclans.

The dances are seldon announced before sundown of the day on which they are to be given. At that tine the mus1clans wake a round of the plaza, playing their instruments and followed by the Bmall boys and most of the many dogs of the village. The nolse made by the musletans $1 \mathrm{~s}$ greatly augmented by the shouts of the boys and the barking of the coge.

These dances are always held in the school house. Chalra, desks and other sohool equipment are cleared away with the exception of a single row of aeate that run along each side of the bullaing. These seatis are so placed for the benefit of the aged and the younger dancers during the several brief rest pertods of the evening. 
The orowd begins to gather about 10 o'olock, f1ling in In seall groups. The girls must come in groups or in corpany w1 th their parents as no unmarried daughter would be allowed to come alone or in company with an unrelated male. They 111. slowly into the bullding, the girls seating themselves on one slde of the roon and the boys on the opposite side. This division of the sexes is maintained throughout the evening except when the dances are in progress.

As wentioned above, the dance tunes are largely of Spanish or liexioan origin and generally aro of an extremely fast tempo. The dancing oouples bwing around at an amazing rate of speed which one can hardig belleve posalble to maintain for more than a brief perlof of time. As a rule the male does the greater part of the danolng while his partner assumes a more stolcal role of following him around.

The old people, as well as the young, attend these dances regulariy. It 16 seldow that a person tays away that 1o physicaliy able to attend. Mfany of the older people dance and, desplte thelr age, seen to have almost as much stamina as the younger peopie. Those who are too old to dance usually stay untli the dance 18 over which may be Prom two unt1l four o'elock in the morning. Ch1ldren are brought along and by widnight are tretohed out on benches, in corners, and in the laps of thelr mothers all aroung the roon.

Although these dances are enfoyed tremendously by 
everyone, Joung and old, they are, primarily, a form of recreation for the young. They are almost the only recogalzed means of contret between the unmarried boys and girls. As a result, wost of the dances are sponsored and pald for by the Joung, unmarried males of the village.

\section{Religion and the Ghurch}

The people of El Cerrito are 100 per cent Cathol10. The oburch and 1 ts teachings play tremendously important role in the attitudes, praotices, and everyday life of these people. It 1a the earnest desire of every individual to 1ive entirely within the dootrine of the chureh.

E1 Cerrito has no resident priest. The village is too omall and poor to oupport one. The priest that serves $\mathrm{BI}$ Cerrit to 11ves in the nearby village of Villarueva. He comes to the village once a month to conduct mase anä to hear confesbions. In case of a death, or a bimilar energenoy, he may ake apecial visit, but the average year would necessitate no more than two or three extra visits. Abeence of the priest, however, does not mean that rellglous services are not held regularly at least once per week. The people congregate each Sunday and sometimes as frequently every day of the week in the church. These extra cervices are in charge of a local woman who di celected and pald a tee by the church. The servioes are conducted in a very humble spirit. 
The women seat themselves on the benches and the men kneel on the hard floor in the rear of the church. The attendance is usually good. There are never many who are able to ratlonalize staying away. All present take part in the serviees. The hylans and ritual that are part of the service are well learned, even by the very emall children.

After the services are over the men meet in front of the ehurch for a hale-hour or more of conversation. phis 16 as much a part of the service as any of the formalized ritval. Such meeting afford the men their most frequent opportunity for getting together in a group. The conversation 18 alreoted to the entire group. The toples are generally local happenings or any news a recent visitor has brought back from town. The group never breaks up unt1l each man who hae something to offer has had hls say. The local priest serving El Cerrito has a status not. approached by any other individual in the locality. This 18 easily understood wen it is reallzed that he is the sole and undisputed representative of the church and the only man in the area with any signifleant amount of formal education. Consequentiy, his word is authority and beldom questioned on worldiy or on religlous matters. During the. recent perlod of heary rellef in the area (1933-1940) many priests assamed the responsiblilty of acting as intermediary between the people and the governmentel agencles operating in that part of the state. The polloles and procedures 
or these agencles were new to the people and the priest was the only source for elearance. lany looal agency representat1ves are Irank to admit that securing the support of the priest often meant the difference between the sucoess or fallure of progxan in a particular viliage.

Tho ohuroh in il cerrito 1 s not a self-supporting inatitation. Although meager monthly contributions are made by the people, these are not surficient to absorb the total. cost of the churoh's prograt. When the famliles were quessioned as to thelr annual churob dues none estimated that they aggregated more than $\$ 5.00$ per gear per fam11y. In addition to regular servioes the churoh sponsors other activities in the vilage. In one of these the village holds each Jear a commity funotion in honor of its Patron Salnt. Whie celebration is one of the most gala affalre of the gear. This function 1 . held in December and lasts for two full days. Elaborate males and procedures have evolved to govern the affalr. Although the v1liagers eponeor and conduct the tunction, the priest is alvage invited to attend as the guest of honor.

Two leader are eleoted each year to be reaponalble for the conanct of the funotion. It is the1r duty to invite the priest, to provide food and drink for 211 , to open their howes to accomodete the guests, and to suparvise any other detalle of the afralr. It 18 considered an honor to hold one of these posts, and, providing he can finance the 
several costa, a regards himself as fortunate to be elected. The financlal status of the cendidates is alwoys taken into consideration in the eloction in order that the camaldater elected may be able to assume the flnanelal responsibility. The terw of offlce is for one year only. No one wan is expected to serve two years in succession al though the same man often serves in alternate years.

These runetions begin on the eve of the patron gaint's birthday. Food and drink have been mede roady in lazge quantities and spread out in the howses of the two church leaders who were elected at the funotion the previous year. Visitors, nelghbors, and relatives file in and out of the houses at will, partaking of the feast at their pleasure. This continues until. late in the afternoon, when everyone warches to the churoh for special service. After the service is over they come back to the houses, where they may agaln take tood and Arink if they so deatre. The last reature of the evening is the danoe which, 11ke the others, begine at about $100^{\prime}$ olock in the evening and lasts unt11. early morning. The seochd day of the affair $1 \mathrm{~s}$ sinply a duplicate of the first.

Another feature, celebrated in 1 l cerrito and highly typical of the area, is the striot observanoe of Holy Friday. Th1s 18 an event which prohibits 211 sorts of manual laior for the day before, the day after, and including holy Friday. It 18 the one time of the year when all the viliagers wear 
their best clothes and the men are clean shaven.

Churoh services are held during the morning, afternoon and again in the evening on Holy Friday. Each of these servioes 18 announced by the clatter of an old wooden eatraca that looke very much like an anclent coffee grinder. The ohurch bell is silent until the final orvices are over. The observance of Holy Friday by the people of El Cerrito is not a somber oocasion. On the whole 14 is a gay affalr, a time for netghboring and friendry exchange of gos81p. It is a day when the homenakers $\nabla 1 e$ with one another In the preparation and exchange of food. Small boys and girls are kept continuously busy running from one house to the next with trays of food to be sampled.

\section{Soc1al Partiolpation}

As Table $v$ clearly indicates, the formal soctal i1fe of the El Cerrito people 18 extrenely inated 11 participation in church services 28 excluded. Out of a total of 183 formal meetings of all organizations held during the year 154 were ohuroh service meetings. The attendance at there meet1ngs was approximately the same for the male and female fanily hoads.

Next to the church services dances were the most Prequently attended of all soolal evente. Of the 26 formal dances held during the year 1939 ench male and female head reported having attended 50 per cent of the time. Personal 
observation over a major portion of the year 1940 loads the writer to belleve that the actual attendance figure, for both male and fenale heads, was considerably higher.

Table v. Social Partiolpation of Heads of Fam111es, E1 Cerrito, Now Mexico, 1939

\begin{tabular}{|c|c|c|c|c|c|}
\hline \multirow{3}{*}{ Type of Gathering } & $\begin{array}{l}\text { Thinder } \\
\text { of } \\
\text { :Meetinge } \\
\text { :In Year }\end{array}$ & \multicolumn{2}{|c|}{$\begin{array}{l}\text { Average frumbe } \\
\text { of Times } \\
\text { Attended }\end{array}$} & \multirow{2}{*}{$\begin{array}{l}\text { :Averag } \\
\text { : Expend- } \\
\text { 1 ture } \\
\text { : per } \\
\text { : Fantiy }\end{array}$} & \multirow{2}{*}{$\begin{array}{l}\text { :Average } \\
\text { :Dls tance } \\
\vdots \text { to } \\
\text { :Meeting } \\
\text { :Pleee } \\
\end{array}$} \\
\hline & $\therefore$ & : Male & : Remale & & \\
\hline & 164 & 144.4 & 146.1 & $\$ 3.21$ & $81.7 \mathrm{yds}$ \\
\hline Educational meetings & 1 & 1 & 0 & 0 & 79.4 \\
\hline B1toh connission & 1 & 1 & 0 & 0 & $82.4 "$ \\
\hline Political neetings & 1 & 1 & 0 & 0 & $83.3 n$ \\
\hline Danees & 26 & 13.4 & 13.4 & 0 & \\
\hline
\end{tabular}

The money cost of partiolpation in the local soolal life was almost nil as may be seen from Table $v$. None of the families Indicated any expenae for these 1 tems outside the church. The average flgure for church expenditure was only \$3.21 per Samily.

Al though these rigures indicate a very meager formal 8001 lal 11fe for these people adequate flgures would show an abundence of informal social particlpation. The physical structure of this village greatly facilltates informal contacts. All houses in the village are within a stone's throw of one another. See Figure 1. Through yeara of interdependence, the people are conditioned to call upon nelghbors 
and relatives for mang types of assistance and, in turn, are expested to reolprocate when the need arises. Any tagk that requires greater strength or physical effort than a singlo randy has at hand 18 solved by calling in one or more nelghbore. Such service is treely asked for and fiven. In case of siokese or cimilar miefortune the offorts and resources of the entire village may be utilized in order to bring the fanily throagh the erdals.

Informal visiting far exoeds any other mode of contact between the v111agors. The 1atchstring 1s "always on the outside for any nelghbor or relative who may have the time and Inclination to call. In a single alternoon fourteen different vistors were counted coming to one housebold, some of them returning as wany as three and four times. This was not a peoullar case. Other homes in the village probably had as many. Guch vists are expected. If a housem W1fo falls to wake a call in the aftemoon it is taken for gravbed that she is 111 or else has company.

Although $\mathrm{A}$ iting 10 general in El Cerrito, the degreo " of blood relationahip 18 the chief factor affecting their Irequeney. The house of the parents of geveral married non and daughters 18 the nucleus for the different viglting groups. The wres and children of such families may cone to the central houge a dosen or more times in a day. They cone to distribute a b1t of news or to borrow a 11ttIe something for the next meal. The children are continuousiy 
maning into and out of each other's houses. They are together so mueh 1t 18 difficult for an outsider to learn the houges in which they beleng.

Although the risiting of the wonen far exceeds that of the wen, each day afforde the men ample opportunities for cont acte and conversation. After a day in the fleld is over they are 11kely to meet for short time around the house or in going to or coming from the corrals. Also for the men there are other opportunities for contacts, such as the fleld work, the local meetings, and the trips to town.

Little visiting is done outside the village. Phis is eapecially true of the women, who geldom see a woman from the outside. The wajority of the women of El Cerrito do not leave their village more than once or twice each year.

Panily Fisits outside the village are usually to the homes of relatives in the larger toms. Such trips serve three main purposes: a chance to remain in town for a few days, a chance to make periodic purchases, and a chance to visit with Iriends and relatives. These visite ang lest as mach as a week. That such vialts are seldom repald does not watter. Suoh hospltality 18 acoepted by both parties as a responsibility the tow people owe to their country relatives.

Marriage and the ramily

There are only a few adults in El Cerrito who have never married. Por a boy or girl to remain unmarried too 
long is to mak a loss of status in the village. Th1s 16 especially true for the girls for whom there is no other career than to become a housewife and the mother of children. The rast majority of the people marry at a relatively early age. See Table VI. of the 19 unbroken familles 11 ing In the village eloven of the female heads had been married under twenty jears of age and eleven of the male heads had been married under 24 years of age. only two of the worken were married for the first time after they were 25 years old. The average age at maxriage for both male and female heads was $108 \mathrm{~s}$ than 22 years. ${ }^{12}$

Table $\mathbf{x}$. Age at Marriage of Male and Female Heads of Households, El Cerrit to, New Hex100, 1940

\begin{tabular}{|c|c|c|c|c|c|c|c|c|}
\hline Age at zarriage & & & $\bar{\vdots}$ & Total & $\begin{array}{l}\bar{\vdots} \\
\vdots\end{array}$ & male & 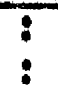 & Penale \\
\hline Average ag & & & & 21.7 & & 24 & & 19 \\
\hline $\begin{array}{l}\text { Bnder } 20 \text { years } \\
20-24 \\
25=29 \\
30-34\end{array}$ & $\dot{\bullet} \dot{\bullet}$ & & • & $\begin{array}{r}11 \\
17 \\
9 \\
1\end{array}$ & & $\begin{array}{r}0 \\
11 \\
7 \\
1\end{array}$ & & $\begin{array}{r}11 \\
6 \\
2 \\
0\end{array}$ \\
\hline Tetal & • & - & - & 38 & & 19 & & 19 \\
\hline
\end{tabular}

Marriage 1s an event in the 11 fe of an El Cerrito boy or girl that is equalled in importance by fell other ocoasions.

$12_{A}$ tabulation of the resords of the local church rerealed that, out of 296 marriages contracted within the local area and during the last 25 jears, all but a snall fraotion of both males and fenales were married under 25 years of age. Wen plotted on a Braph two modal ages were revealed for the men, the first at 21 and the second at 36 . 
The ceremony, and the process leading up to 1 , are equally ritualistie in the formal manner in whioh they are pract1eed. The exot1o features of both are Span1sh, or perhaps Roman, In origin and have beoome only slightly modifled in a hudred years of oontaot with another cul ture.

Unt1l approxlmately twenty years ago local marriages were influenced greatly by the parents. In this manner land and other properts holdings could be consolldated advantageously. Reently, however, this practice has become much less common and a boy or girl may choose h1s: own mate with 11ttle interference from parents or other relatives.

The parents still play a minor role in the matchmaking even though it is only a restige of the authority they once welded. The prospective orldegroon's parents, usually the mother, still via1ts the parents of the bride-to-be and discusses the matoh with them. After the dircussion she leares a pumpkin with then and if the pumpkin is not returned the natch 18 conshared as made.

The brldegroom furnishes the troussean of the bride. since this is somewhat expenstre and since, too, he must have "open-house" on the der of the wedding, it is sometimes extremely diffeult for the boy to acoumulate enough weal th to finance a wedding. A number of the younger men of the village admitted to the writer that their weddings were postponed for Irom one to five years as a result of their Inability to accumiate sufficient funds for the cerewony. 
The day of the wedding a spirit of plesta pervades the village. The parents of the groom have given thetr house orer to the young couple and enough food and wine for all has been prepared. The doors of the house are kept open all day and the pillagers may come in for food or drink at any time they choose.

The wodding ugually takes place in the morning, el ther in the looal viliage or in the village in which the priest 11ves. After the ceremony the couple must go to the plaza to have their ploture taken in their new finerg. Phis is almost as Importent as any part of the cerenony. Such p1ctares are distributed to many close relatives and one 18 always brought back to be hung in the house. This is about the only occabion in the life of elther bride or groom when there 1s opportunity or the elothes to really "dress up." After the ceremony has been perforwed and the piotures takes the bride and groom return to the village where they are the hosts to the v1llagers. Fhis continues until the evening when all attend a dance which has also been sponsored and paid for by the groom. These dances may well last until 4 or 6 olock in the morning as everyone tries to keep the new couple from golng home as long as posstble. The entire set of values by which the local people live are woven around the inetitutions of family and church. Lojalties, responsiblilties, and duties are primarily connected wt th the meaning of fanily. The esteem for an 
Indiridual in the community comes out of contributions or failures in relation to this institution. The primary virtues that give an individual or a fanily prestige in the village apring from the conduot of the family group. Fam11y in El Cerrito means more than parents and offspring. It also, in the real sense, includes grandparents and grandehlaren as well.

In the Bl Cerrito family the father 18 aefinitely the head. H18 word 18 family law and, within all bounds of reason, will be recogni zed as such by the other people of the village. It is the father who wakes all final deelsions, handies the finances, and provides for the weliare of the fam11y. The place of the mother 18 in the home. It 18 her duty to look after the household, do the household chores, and bear and rear ch1ldren.

To be recognized as a good clizen of El Cerrito a man must aupport, not only his ow imediate family, but give what ald he can to parents or to any other near relatives in need. Fallure to do this bringe soclal censure in its most formidable form. Living in accordanoe with thls code bring respect of the ligheet order.

There is a very high degree of blood relationship between the fanilles of EI Cerrito. This is well demonstrated by the fact that there are only geren family named in the v11lage. Each fanily 18 at least distantly related to overy other fanily. In fact, these blood relationahipa have 
Increased over the jeare to the extent that no marriages have taken place between the looal villagers within the past Ifteen years. The last marriage was severely censured by the local priest bocause the bride and groom were second cousine.

\section{Education}

The school bullating in El cerrito is an antiquated, tro-room structure that was evidently bullt with 11 ttle more than certaln anount of space in mind. The furnishings and oquipwent are in keopling with the bullding. The lighting arrangenent 18 very poor and the heating eyster consista of two wood-burning stoves, one for each room.

This orude building houses from twenty to fifty puplis, depending upon attendance, in addition to the two teachers. Instruetion 18 given in grades one to lght inolugive. The school 18 conducted with littie stpervision from the county egeten. Roads are too poor and the distence from the county seat too great for a supervisor to come to III Cerrito more than once or twice during a shool year.

Attendance at the sohool is poor. The girls attend more regularly than the boys, especially after reaching the higher grades. After a boy has reached the age of twelve or thirteen he is expected to ald in supporting the family and 1 often kept out of school to help the father or to h1re out to angone needing his services. For this reason, 
fen of the boye complete the full elght grades of sohooling offered unless they do so at a very early age. See rable VII

Table VI. Grader in school Completed by Males and Females Above 25 Years of Age and Mot Attending School El Cermto, New Hexico, 1940*

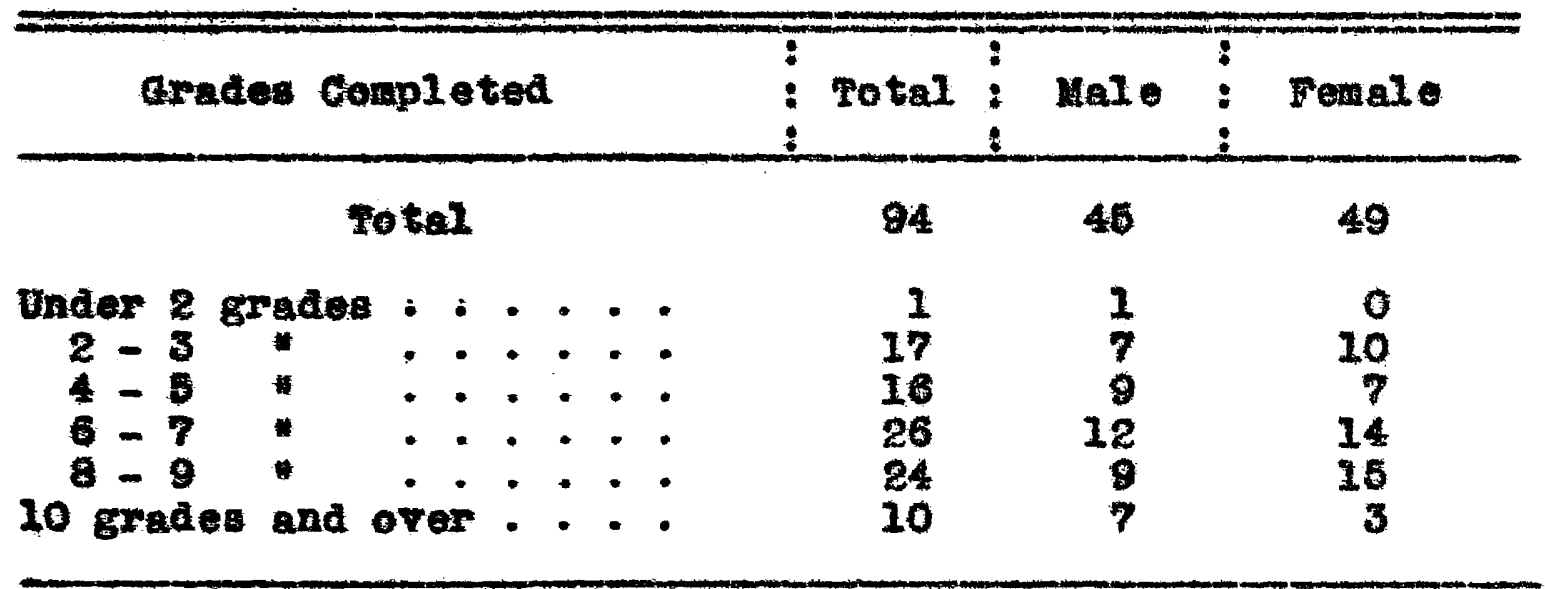
eleowhere.

These Plgures laclude Tanily membere now IIVIng

Ao Table VII Indicates the girlo usually continue in sohool somewhet longer than do the boys. Elghteen of the fenal es reported having completed elght years of schooling or more as compared with sixteen of the males.

The wal o6, howerer, more frequently went beyond elght grades. This, obviousiy, indicates schooling away from the vilage which would not be permisgible for the girla uniess they oould live, while aray Irom home, with a near relative. The progran of the EI Cerrito school involves no other person than the teacherg and enrolled ohilaren. Parente are nel ther consulted nor do they volunteer any advice relative to the echool and 1 to program. The general conoensus seems to be that the teachers are hired and pald to 
conduct the sohool and can do 1 t best whout any interference from the outside.

There are two occasions during the year when parents are invited to vialt the school. One is at the end of the school term and the other on Chrigtmas exe. At each of these cocas10ns, the chillaren produce a short play on which they have been praotiolng for several months. In these proauctione the ohilaren are given an opportunity to demonstrate to the1f aldera, their ab1lity to speak English. Although the wrds are quite eften unintelifgible the parents are usually highly plieased at the progress their progeny have made. If the parente are pleased the teachers know they have had sucessful jeax.

Despl te 1 ts many Iimitations the local people regard this sohool as one of the wost 1mportant institutions of the vilige. It 18 generally regarded as serving the purpose of orlentating the ohilaren to the outalde world and to some extent to be bxidging the gap that separates the two. Although fow parent expect their children to complete more then elght grades of school, this ininimun is considered to be highly valuable. Any less, they belleve, does not give one an adequte wastery of Bnglinh.

Pew loenl oplnions are ever heard expressed at to how or wat the schools should teach. Other: than Bngl1sh and arthetio there 1s 11ttle consideration given by the parents to what their chllaren are belng taught. It is generally 
belleved, however, that the primary runotion of the schools 18 to teach English. If the schools do a satisfectory job or teaching art thetio and Englioh the people are satisfied. The renalnder of what a child should know can be taught by the church and in the hone.

Deapi to the desire of the parents to have their children learn Englieh well, it lo seldom that a local boy or etrl attains any degree of proflelency in the use of this langaage. The girla nerally speak 1 much better than the beys, probably as a result of thelr longer and more regular attendance at school.

From a standpoint of educational achlevement the teachIng personnel of the local school is usually of the poorest quality. It is diffoult to induce well trained teachers to oome into 1solated villages ouch as Bl Cerrito where 11ving conditione are 60 diffiont and salaries so low. During the year of ourvey both tenchers were of local extraction, one of them from the villago. Since these teachers know Ipaniah $1 t$ was extremely alficult to forse the students to apeak gagliah al though a state statute requires that nothing but gaglieh be spoken on the sohool grounds.

Peaching techniques and materials are not adapted to the peeviar problems met in the local school situation. 13 the cole means for lmparting knowledge is a group of

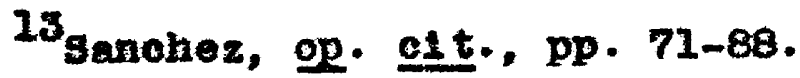


standardized textbooks. Any other equipment 18 devised by the teachers and fashloned out of tin oans, boxes and other orade material at hand. Ho consideration is given to the faot that the pupils are learning a new language in addition to stook waterials which they are required to master. Such aubjeot matter as geography, history, and heal th is taught in terme entirely foreign to the pupil axperience and background. During the school year 1939-40 a visit to one of the clasareons dielosed that the pup1ls were belng required to work out posters and other manual projects based on such phenomena as transportation in Boston and the importance of geogrephy in the growth of chleago. Under such a currioviun as this it 18 amall wonder thet pupil intereat 18 at a snimuin and that progress is slow.

\section{Po11t10日}

Polltics, as a form of aotivity, is particlpated in by 211 the male adults of $\mathrm{n}$ Cerrito. Hection "season" is looked forward to with a great deal of enthusiasm, al though there have been few candidates for county offlee, from the village, in the history of its settlement.

The area in which Cerrito is located has long been regarded by county pollticlans as the area in which a county olection may oasily be deolded. A local atory has it that, unt1l comparatively reoentiy, a candidate farorable to the area used to call the b1g sheep men of the area the aftermoon 
of the eleotion and aak "how wany rotes to you have for mer" The anstrex would be "how many do you needi" and the neoessary ballets would be hurred into the county agt. Whis gave rise to a 8111 current expregson of voting the sheep."

Unt11 1932 the village was 100 par cent republican.

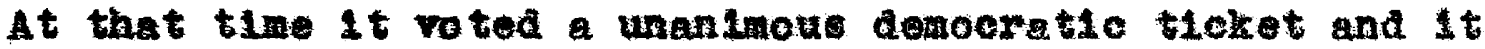
has remained democratic in all subeequent elections. In a revent sate election the villagere roted solldiy agalnet a republican eandiate for a tate offle even though the eandicate was a native gpani eh-Anerican product.

A eandidate for any off1e 1 eppralaed in MI cerrito In texms of what can he do for us." Pol1tion, moral, or rel Iflous prinolples are of seoondary Importanoe. HIs att1 tude tovard national or state lestes that do not consern then alrectly is given ocant attention. Instead, he 13 measured in teme of the number of jobs and the anount of grants and Felier he has obtainea or is 11kely to obtain for his constitueats. In m cermto, theoe are the things that matter.

Inch of the machinery for operating looal politica 16 -1a. offle holders and new candidates st11l court and retain the good will of their constituents by meane of free 
danoes, Free arinks, and now and then a flesta. ${ }^{14}$ These "hand-oute" axe expeoted and a candicate that would choose not to eater to the roters in this manner would have ilttle chance of winning an election. People are Induced to come Into tow by the score when one of these events is announced. To the old polltieal machlnery in the area there have been added reoentiy oertain small, new elubs through which the people are able nore dareotly to make their needs and voting strength known. Predoninant in this fleld have been the political elubs which cater to the jounger people. These clubs are operating in most of the 11ttle villages of the area, E cerrito not excepted. These olube have their own elected officers. Infrequent weetings are held in which the men alsous their political problems in their own way. Any politioal seeting or raliy in El Cerrito inoites a great deal of enthuslasm and draws good attendance. The Milage has 1 ts well-reoggnized best speakers who are always present to talk at great length and in glowing terms of their favort te candidates. Such meetinge are dynamio affalrs, thoroughis enjojed by all present. The polltical 18sue or candidate 28 often completely lost sight of in the 11ght of a passionate and dranatic address. Such apeeches are

14 These practices have encoureged a great deal of graft in the loeal government. A candidate for county offies in 1940 told the author that the office, which paid ilttle more than $\$ 100$ per month, would net him $\$ 10,000$ in two yeare in offioe. 
remenbered and diseussed more from the standpoint of presentation by the speaker than from any content the speeoh might have had.

The village of El Cerrito is peouliar in this area in that it has no sente internal politioal diffioulties. The faot that the village has no faotions enables the people to work in unison. This could be duplicated in only a few Spantsh-Amertcan villages in San liguel county. In most of the villages two or more antagondstic faotions exdst that preclude any possibility of the people working together as a group.

\section{Level of Living}

In terms of oan 1ncome and material goods the familles of 1 Cerrito are certainly not above the poverty line. 15 The arerage cesh femlity incolie for the oalendar year of 1939 wae only 294.16 See Table VIII. This was 150 per fanily leas than a V1llage studied in the lower Rlo Grande area of Hew Mexico in $1938 .{ }^{17}$

16. S. Romtree, Poverty. A study of Pom L1fe, New York: Longmane, Green and Co., 1922, p. 160.

16.1 though this rigure does not inolude producte sola from the fara such 1tems were negligible in 1939 . only 3 fand11er bola products rom thelr farms in 1939 all of which agregated 1 es8 than 100 , with the exception of sheep and oatte cold by two of the throe femil1es..

${ }^{17} \mathrm{C}$. P. Loonte and 0 . F. Leonard, 3 tandards of Living In an Indian-1exican Viliage and on a Reclamation project. Weshington: thited B tates Departoent of AgriouIture, B. A. E. Soclal Research Report Ho. XIV, 1938, p. 13. 
Table VIII. Averages for spoelfied Itens, EI Cerrito, New Mexi 00,1940

\begin{tabular}{|c|c|c|}
\hline$I$ ten & $\begin{array}{c}\text { Munber } \\
\text { Reporting }\end{array}$ & $\begin{array}{r}\text { Ararage } \\
: \quad \text { Reported }\end{array}$ \\
\hline 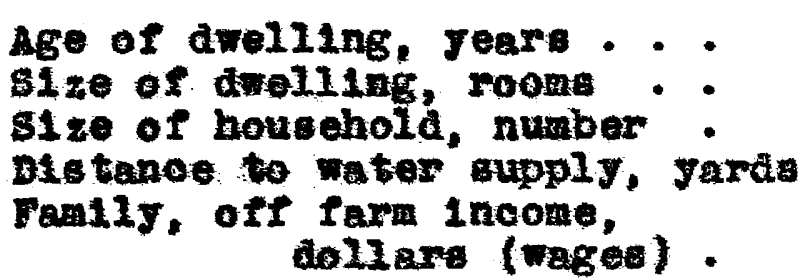 & $\begin{array}{l}20 \\
20 \\
21 \\
21 \\
18\end{array}$ & $\begin{array}{r}63.7 \\
3.96 \\
6.33 \\
96.29 \\
294.0\end{array}$ \\
\hline
\end{tabular}

- Excludes 2 omers of large aoreages and one teacher. Ho oash income fron farm for any but 3 fam11108.

As pointed out earifer, the 11ttie patches of 1rrigated land in the v11lage make 11ving in the looal valley possible with the ald of the little cash earned from working outeide. Suoh patohes are usually gufficient in extent to produce almost all the food that goes on the table during the growing eason and provide some food, in the way of canned fruits and regetables, for the winter months.

Al though the houses are small and old (see Table VIII) they are fairly adequate for the ollmate. Constructed of adobe, a sun arled briok of mud and straw, they provido excellent protection from the cold winters and ample Insulation against the heat of the sumer aonths.

such houses can be constructed at an amazingly low cash cost. Ho material need be bought outside of windows and doors unless the femily 18 flnanclally able to purchase shoet 2 ron rooring and wooden flooring. At the time of the writer's stay in the village in 1940 a newly married man 
bullt a three-room house for a total ozeh outlay of 87 which ineluded the rough board flooring. Had he chosen to endure dirt floors the cost would have been considerably 10 s.

The rumiture in thowe houses 18 generally soant and of the sieplest construetion. Some of it is hand-made but this is a oraft that 16 rapidly disoppearing in the aroa. A typloal bedroom w111 contain no more than bed or two, a table, tove, and posstbly a chest of drawers. The k1tchen furnltare will consist of a tove, table and elther some benches or chatre.

The arinking and other water for the household is oarried in palls frap the 1rrigation diteh whtoh runs along the village boundary. This water is carried by the wonen and amall chllaren ovor an average distance of approximately 100 yards.

Glothing ooete are held at alnimun. Very littie new clothing is bought expept at speotal ocoaniong such 9.8 a wedding, or the annuni conrimation of the children by the churah. Clothing is handed down extensively from larger to gnallex brother or sleter. Hore fortunote relatives are depended upon heavily for gifts of cast-off shoes, sults, dreses, and hats. 


\section{CHAPTER $V$}

THE ROLE OF THE LAND GRANT IN THE SOCIAL ORGANIZATION AND SOCIAZ PROCESSES OF A SPANISH-AHERICAN VILLAGE

IN NBW MEXICO

Almost 350 years ago the flrst contingent of Spaniahspeaking colonists arrived in the territory of New Nexico to begin period of settienent in the area that has continued to the preaent time. The early spanish colonists brought with then, as part of their cultural heritage, a definite schene for setting the land. This scheme included auch faotors as: a definite form or pattem of settonent, spee1f1e ways and measures for alviding the land among themselves, end pre-coneelved 1deas of land tenure and other coelal relationshlps between the population and the land. Settlements in Nem lexico were almost universally 10cated on existing streams of water in order that the fam111 es could earry on the combination enterprises of irrigated agrioulture and tock-ralsing. This practice was continued throughout the $3 p a n i s h$ and $h$ extaan perlod of occupation and at111 remains as a triking feature of the oultural landsoape.

Dry or pasture lands were abundantly avallable, stretohIng out in every alrection from the settlement center. 
Private titles were granted to some of this land and that reasining was used with no thought of exclusion or trespass. Irrigated holdings, on the other hand, were 11 mited and asalgned to individuals. In diviaing this irrigated land the river or other strean frontage was the place of departure. Dewally the holding consisted of long, narrow strips that might extend across the entire village settlenent.

Titles to the Iand were granted by the Spanish crown and later by the Mexican Republ1c. They were usually phrased In amblguous and inderinite terms in both respect to the terr1tory granted and the rights extended. Boundary I1nes were vague and confusing, stretching from one natural objeot to another and ut1lizing many markers that might change or else disappear al together over a short perlod.

Unt1l the American ocoupation of the territory in 1846. the problems of indefinite and indeterminate boundaries, legal titles of ownership, and Indisoriminate use of the land were not particularly acute. Density of population was slight at this time and aple grazing and pasture land for all seem to have been avallable.

When the area became a part of the United States, however, the task of establiahing definite boundaries and t1tles began, a prooess that lasted until early in the 1900's. This task was extrenely complicated by a number of factors such as lack of adequate records, retioence on the part of 
the people to submit olalme, and perhaps most fundamental, the many diffioulties involved in the superimposing of one type of land agstem upon another. 1

It is the thesis of this paper that these phystoal factore, in thelr early nature and in subsequent ohonges, have been of some considerable influence on the soclal organization, Institutions, and soclal processes of the people in contact with thew. As smith has pointed out such sooial factors as "the relationships of farmers awellings to the land and to one another 1 basie to all rural soelal organization and consequently a logloal beginning for any analysis of the structure of rural soclety $!^{2}$ The nature of this influence as revealed by the tudy of a selected Span1sh-American village, and something of its extent, is developed in the following pages.

Brief History of the Land Grant in Hew Hexioo

The land problen in New fexleo has probably been as tangled as it has in any of the other states of the Union. Land grants from the Crown of Spain, succeeded by those

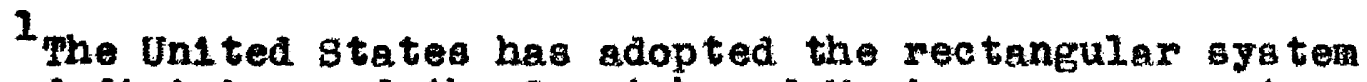
of land division and the Spanish and Mexican governments used the river front and inderinite natural boundaries.

2 $T$. Lynn Sm1th, "An Analys1s of Rural Soclal organization Among the French-Bpeaking people of Southern Louls1ana," Journal of Farme Econom108, XVI, 1939, p. 680 . 
given by the Mexican Republ10, and Finaliy the 1nclusion of a Iarge part of New Mexico in the Public Domain of the United states, all combined to produce a state of confusion that took a half-century of I1tigation, plug surreg after survey, to untengle. Not only have the people of New boen Imashed in numerous disputes and legal complications, but the conteste over titles have involved people of other 8 tstes and other countries as well. As a student of the public land policy of the united states has observed wh thout exaggeration relative to large New Mexico grant of land, "1t affected high officials or prominent business men in America, England and Holland. It produced guerilla warfare In New Hexico and wid scramies on the Amsterdam stock exchange. ${ }^{3}$

The oldest grant in the state of New Mexico, of whloh there 18 record, is the Cienegullia grant located in Santa Fe County, The petition for this grant was allowed by the Spanish Grown in 1693 and conflrmed by the Enited States government in 1899. There are doubtless many ofder grants In the state, the papers for whlch have long been lost or destroyed. 4

There are no records avallable which indicate the

3 Harola $\mathrm{H}$. Dunham, Government Handout, New York: Edward Brothers, 1941, p. 214.

${ }^{4}$ coan, op. o1t., pp. $475-79$. 
exact number of land grants conferred by the Span1sh Crown In Ner Mexico, nor even approximate Iigures as to the acreages Ineluded in then. 6

That the number wust have been a hundred or more, howerer, is Indicated by the fact that between the yeare 1693 and 1821 a total of 61 vere granted and retalned sufficient eridence of titlo as to be confirmed by the United states goremment after 1 ts possession of the territory in 1846.6

After wexico took over the territory of New Spain in 1821, the aetlement process in New Hexlco was speeded up considerably. From the time rexteo assumed jurladiotion over the territory in 1821 until the war with the United States in 1846, that Republ10 granted 30 petitions of settlers for land that were later conflmed by the Un1ted. states. That there were many more grants allowed during the period there can be 11 ttie doubt as many of the clains were never brought before the United 3 tates authorities for examination.?

Irpes of land grants: There were throe types of land grants

5 Then the Spanish government was driven out of Santa Fe by the Pueblo Indlans in 1680 almost all government records were destrojed 1ncluding the territorial Iand reoords.

6coen, op. c1t., pp. 475-79.

7 Thomas Donalason, The Publio Domatn, House M1soellaneous Document 45, 47th Congress, 2nd session, XIX. WashIngton: Government Printing office, 1884, p. 406. 
allowed by both the spanish and Mexican governments. They. were (1) the community grants given to a group of settlers or "communt ty," (2) Individual grants, given or sold to persons of some financial means, and (3) joint granto to a few Individuals. 8

Al though the avaliable evidenoe on the 18 sue 18 IIn1ted, It seeme that most of the Spanish and Mexican land grante were of the town or community type. 9 These grants were awarded to a group of petitioners who had banded together in order to better brave the dangers and privations of early ploneer 11fe. Lands $g^{17}$ en to these settlens were of two varieties: farming or Irrigable land, to which the Bettlers were given titles for Individual tracts; and common or pasture lands which were for the communt ty to use in

${ }^{8}$ Al though these three types of grants are defined here, the tention of this paper is 11 imited to the community type. The reasons for this are two. First, the rajority of the original grants were of the community type. second, W 1 th but few exceptions all grants in New Mextco eventualiy bocame comminity grants wi th the addition of new families of loeal origin or 1migration. By 1854, when the office of the surveyor-genergl began hearings on land cla1ms, and most of the information to be had on these grants became avallable, there was little distinction between the type of claims regardless of the orlginal type it happened to be. For these reasons 11 ttle attention 18 given in this paper to Individual or joint grants.

9 Ibia., pp. 406-408, also Coan, op. c1t., pp. 475-79. It might be pointed out here that grants to Indian pueblos, and military garrisons are omitted from alscussion here sinoe they were of an entirely different natare. 
common "rich and poor allke." Land given to the towns or comunities was called realengos or royal lands since the rull title to the lands remained in the crown and only the right of use and ocoupation was transferred to the people. In many oases, however, the individual grants of farming or Irrigated land might be sold or otherwise disposed of after a certaln number of yearg. (see Append1x B.) The early settlers in these town or communtites may have been of the ne'er-do-well kinds, although the quality seems to have Improved durlng the later perlods of Spanlah occupation. As Blackmar has stated 1t, "the first settlers, though mostly spanish, were of an inferior class, whose numbers were Inoreased from time to time by invalids and discharged soldiers. But. . . the charaoter of lmigrants improved unt11 the settlenents were represented by sowe of the first tanil1es of Spain and wexico."10

The joint grants in New Hexico were similar in many. respects to the town or comunity grants. Whese grants were given to a group of familles usually ranging in number fron two to ten. The grantees in this case usually were responsible for elnancing the settlement venture al though they aight be given or loaned funds by the government to offeot partially the costs. Families and individuals

10 Prank w. Blackmar, Spaniah Inat1tutions of the Southwest, Baltimore: The Johns Hopkins Press, 189I, p. 186. 
ocoomanying the grantees were giren residential lots and a small portion of irrigable land to t1ll. By and large, howover, they farnished labor for the grantees who as a rule omed large herda of Iivestock.

Wost of the Individual land grants were issued during. the early Spanioh domination of New Mexico. These grants were usually distributed to individuals who assisted in conquering the country as rewards for their services. some, however, were sold to Individual buyers to help defraj the expenses of current colonizing efforts. These lands were oalled de dominio particular, or private property, as the rull ownershlp was usually transferred to the donees or purchasers. 21

The proprletor of the grant was bound by certaln rules and regulations with which he was forced to ablde or else the Iand and 1 to improverents would revert to the Crown. For example, usually he was required to provide sono sort of government of the families brought with him. Thls generally consisted of an alcalde, most rrequently the grantee himself, and town council made up of the heads of resident fan111e8.

Spantsh and Hexican Colonization Policy: The land laws of Spain were liberal in character, especially designed to

$$
\text { 11 Donaldeon, op. O1t., p. } 1126 .
$$


Induce colonists to settle the territory of New Spain. As nentioned abore, not only were colonists allowed to settle on the land free of charge, but in many cases were pald to do so.

Under the Spanish "laws of the Indles" the ownership of all oonquered lands in the "West Indles" belonged to the Crow. However, ownership was often sold to favored purohasers and the ocoupation and use of the lands were traneferred with $11 t+1$ e diffioulty if wh a great deal of formal1ty. 12

There were three types of lands reoogn1zed by the Spanish government in Now Mexioo. They were (1) the consejlles or lands assigned for the suppert of town; (2) the de dominio partioular or privately omed lands which had been sold or g1ven to favored subjects; and (3) the realengos or royal lands. The royal lands were also known as terrenos valdios or vacant lands because nothing was pald for their use. 13

The royal lands, obvlously, lneluded all but a small portion of the entire territory. All vacant lands were designated as realengo lands as were the comons or pasture lands surrounding each sottlement. Use of these lands was

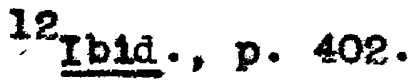

${ }^{13}$ Ib1a., g; 1126. 
granted the settlers to the extent needed for the1r plocks and herde, who accepted this pripilege as a matter of course.

In the early jears of settlement petitions of the settlers for realenge lands were nade directly to the king. This proeedure was expensive as well as time ooneuning and a royal decree was 1 ssued in october 1754 aking it possible to aubit the petitions to appointed delegates residing in the territory. ${ }^{14}$ phls decree was instrumental in speeding up the rate of gettlewent in the territory.

other royal decrees were 1ssued in subeequent years relative to the disposition of the public lands, culsinating In the deoress of 1791 and 1798 which made in unneoesaary to apply to the politioal counc1l for approval of any landa valued at less than 200 and gave the local m111tary captains authority to confer grants within the vicinity of their garrisona. Under these ordinances and modifleations grents continued to be made in the territory unt1l the revolution of 1821 when fexico gained 1 to independenoe from Spain and took possession of the territory. Thus, in oumary, it 18 seen thet:

the constant pollcy of Spain was to encourage by all meens the settlement of her possessions in the New Forld; that, while the absolute ownership of the realengo lands was retained by the crown, laws erora time to t1me were passed for the purpose of enabling

${ }^{14}$ Ibsd., pp. 1126-27. 
actual settlers to obtain titles to so much of these realengo lands as they required for thelr use and occupation in the puraul ts of agrioul ture and atockralsing; yet, while the terms under which titles to these realengo lands could be obtalned for actual use and ocoupation were so oasy as to be within the reach of petitioners of humble meane, st111 the government guarded with Jealous care thelr disposition by passing such laws as made it lmpossible for the vassals of the king to acquire them for any other purpose than that of actual occupation and use. 15

The occupation of the territory by Mexico in 1821 resulted in few ohanges in the land laws or colonization polleles alroady existing north of the Rlo Grande. There were, however, two changes that are perhaps worth mentloning. The first one, brought about in 1825, required that anyone desiring a tract of land for grazing purposes or agricul ture must submit the petition to the secretary of state. In the. same Jear the territory of New sexico was opened to settlers from forelgn countries providing they "submit to the laws of the country. . . and except for land embraced within the twenty leagues bordering on a forelgn country, or the ten leagues bordering on the seashore. ${ }^{16}$ This latter change was a departure frot Spanish procedure which had prohiblted forelgners from settilng in the area. With these two exceptions the settlement pol1cies of the two countries were the same.

\footnotetext{
${ }^{15}$ Ibld., p. 1227 .

${ }^{16}$ Ib1d., pp. 1128-29.
} 
Under spanlsh colondzation polloy settlers were "enlisted" in very muoh the same manner as if they were beling taken into the ermy. Prior to 1779 oach settler was equipped with all esential tools and equipment for farming and paid a mall alory unt1l he had become self-sustatning on the land. Faoh settler was:

entitled to recelve annually one hundred and twenty dollars, with food for the firat two yours after enlisting as a colonist, and provialons alone for the three following jears . . each settler was entitled to reoelve a house-lot, a tract of land for cultivation, another for pasture (comons) and a loan of suffielent tock and implenents to make confortable beginning. In adation to these, he reoelred two mares, two cows and one call, two sheep, and two goats, two horses, one cargo mule, and one yoke of oxen or steers; one plow point, one spade, one axe, one slakle, one wooden knife, one musket, and one leather shiela.17

In 1799 this regulation was ohanged to give each settler one mundred and alxteen dollars and seventeen cents (\$116.17) for each of the pirst two jears and sixty dollars per year for the next three years. If after five years the settler had t1lled the soll and made certaln lmprovementa on the land ho came into posseasion of an 1 rrigated tract of land for life and the life of his children. These regu1ations, obviously, applied only to the "enlisted" settlers as the large, private or indifidusl grantees were responsible for the1r ow families.

The degree to which this general spanish oolonization

${ }^{17}$ Blackmar, op. 01t., pp. 164-165. 
polloy was executed in practice varied considerably in the different parts of Spanish colonial territory. There 18 I1ttle eridenoe to support the thesis that the polloy was carried out 11 terally with any degree of completeness in the Hew Hexican settlements. 18

After Mexice elned her Independence the practice of subsialzing colonization in the Hew World, as established by Spain, was continued with 11ttie deviation. Under the deeree of 1825 Mexioo allowed "an advanee payment of transportation expenses, a 11ving for one jear after they have settled, faratng tools and bullaing terials for the construetion of thelr houses; an acquisition of deternined traet of land for tlllage and bullang purposes" and other miscellaneous items of household and farming equipage. 19 These Inducententere al so open to forelgners, who, in addition, were entitled to Mexioan naturalization and oitizenchip papers. Forelgners were also exempt from payment of 1mport duties on the goods and equipment transported into the territory.

Government of the settlenents was specifically provided for by both the Spanish and Mexican governments. Although

${ }^{18}$ A search through some thirty records of Iand $\mathrm{E}$ rants In the General Land offlce, Public survey office, U. $S$. Department of Interior, Santa Pe, New dieclose any extensive glfts of ilvestock or equipment wentioned.

19 Donaldaon, op. o1t., p. 513. 
aupreme authority resided outalde the territory each pueblo or sottlement had 1 ts local government consisting of a minimus of an elcalde or mayor and a town coune1l. The town coune1l was eleoted by the people and the alcalde was usually appointed by the territorial government. The actions of beth the eloalde and mayor wero subject to review by the government' a representative at santa Fe and often by the captain of the nearest garrison.

Both Spain and Mextco required that the colonists keep a rast assortinent of fighting equipment in readiness to go to the ald of the crown or republic. Although few oalls were made on the settlers for militery duty, thelr bows and arrows and muskets were frequently used to ward off attacks of the warlike Navajo and Conanche Indians. United States Pol10y Toward the Hew Nextco Land Grants: The treaty of Guadalup Hidalgo signed in Mexico on July 4 , 1848, brought to a close the war between the governments of Mexico and the United States. It was agreed in this treaty that, for the sum of $\$ 15,000,000$, the Republic of lexico would release clalin of all but amall part of the territory now covered by the state of New Mexico to the United States. It was further agreed that all persons living in the territory, and electing to remain, would become United States c1tizens and have full protection of their property righte "equally as if the same belonged to oltizens of the United 
Stetes."20 This obviouely meant that all bona pide clains, to Spanish or Mexican Iand grants would be recognized.

To cope with the many and varied claime to land in the. new territory the office of united states surveyor-general was created in 1854. Among the duties of the surveyorgeneral was to wak an investigation of Spanish and Mexican grants and to submit his rindings to Congress for approval or alsepproval.

Soon after the establishment of this offlce claims of . Spaniah and Mexican titlea began to pour In. By 1880 the office complained that since the establishment of the office "more than 1,000 clatms have been flled wi the eurvejor-general, of which less than 150 have been reported to congress, and of the number so reported Congress has finally ected on only $71 . .21$

The diffoulties inherent in the task of the offlee of the survejor-general were many. Numerous grantees vere reluetant to flle their elalms. Only bmall fraction of the land had been surveged prior to 1854 , and on auch of this the work was done none too accurately. Even after the elaine had been acted upon by the surveyor-general' of ofice they had to be subuitted to Congress for confirmation. This alone might involve a palt of two or three years. Donaldson

\footnotetext{
${ }^{20}$ Ibla., pp. $128-29$

21 Ib1d., p. 406.
} 


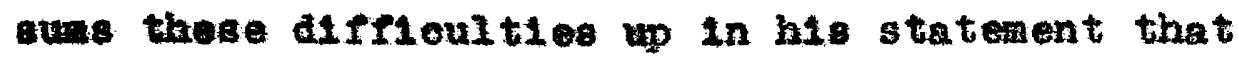

there exist ancient Spanioh titles, munieipal and rural, elalmed under the treaty of 1848 with 1 exico, and whe 18 known $\mathrm{se}$ the Gadsden purehase of 1853. These elatins are for 1rregular tracts, $111 \mathrm{y}$ defined, bounded by treams or marked by headlands, or natural objects in many cases aince removed. They were made for griculture, mining, tock-ralsing, or colonization, in all Bizes from a village lot to million aore tract. The records kept by the grantIng authom tles of Spain and Mex100 have been a Berlous hindrance in come oases toward atiofactory solution, beling frequently of doubtrul meaning. 22

As the task of reviering and acting on all land olalms provod too great a task for the aurveyor-general's offloe the court of private Land Clalms was set up in 1891. to superede 1t. Action was speeded up with this change and the land grant el tuation began to elear up. By 1904 the Court had acted on 301 clains, all but 75 of which were disallowed. 23 The total acres clained were $34,653,340$ and the total aeres confirmed $1,934,986$.

Case Historieg of Certain Selected Land Grante in New

Mexioo: In order to present a somewhat clearer picture of the nature and changes which have taken ploce in the land grants of Hew Hextoo certain data are presented in the following pages on the history of four land grants. It is believed that the four grents selected represent, as well as unch a sall number could, the land grant s1tuation in the

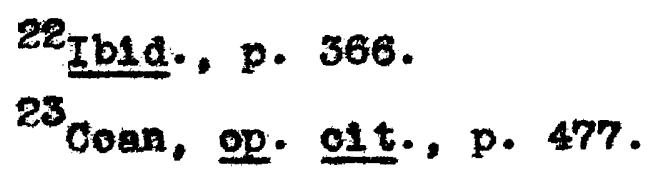


Opper Peoos Waterehed and that it sheds considerable Iight upon the state of affairs in the Spanieh-American area as a whole. Fach of the grants selected is (I) in the Spanish American area, (2) was originally either a Spanish or Hexican grant, (3) was either a conmunity grant or came into commun1ty ownership after a short time, and (4) was character1zed by individual ownerghip of the irrigated land and of the grazing or pasture land in comon.

1. The San Hguel Del Bade Grant: The San Miguel Del Bado Grant is s1tuated in the western part of San Miguel County. It was granted by the orown of spain in 1794 to 52 fantlies then Ifving in the territory of New Mexico. In aceordanee wh the naturel boundarieg set down in the original papers the grant contained a total of 315,300 aeres. 24 These boundaries ineluded a traet of land on each a1de of the peces River, in San Mlguel County, resching from a point just above the prosent village of Anton chlco to a point Just above the village of Upper Colonias.

The settlers took possession of the grant on March 12 , 1803, settling at the present site of San Miguel. Under the direction of the Justiee of Santa Fe the 1rrigated land was divided into strips of land reasured from the river front. After thlo was completed the familles drew lots for

\footnotetext{
24 Doneldson, op. elt., p. 1154. El Cerrito, the v1llage atudied, 18 located on this grant. See Figure 3 .
} 
the portions they were to oecupy. (See Append1x a for detallo of oocupation.) The pasture and grazing lands ware to be held in common for ube by all families.

Certain restrietions acoompanied the grant and wh these all the fanliles were expected to contora. The prinelpal obligations imposed were that (1) the traet (pasture lands) should be held in common, (2) acoess mut be given to settlers who might later come into the area and settle on the grant, (3) each family must have at least one bow with arrows and after two years all must have lirearms, (4) a tract of land must be set aside for the alcalde or mayor of the town, and (5) the construetion of the Pleza, 1rrigation ditehes and other community works must be done by and with comanity 1abor. See Appendix 8 .

Al though the colonist were harased sowewhat by roving bands of Comanche Indians the early settlement at San figuel prospered finanelally and the population of the village increased. A Spanish population census of I827 gave the number of people living at San Higuel as 2,893, number that may have been exaggerated. ${ }^{25}$ A map of the state made in 1844 show the location of La Questa, another village on the grant, indicating that the settlement had begun to branch out. By 1900 all ten of the villages existing on the grant today had already been eablished.

$$
{ }^{26} \text { coan, op. Q2t., p. } 325 \text {. }
$$


The firet petition made to the United statea for a conflrmation of the San Miguel Del Bado Grant was submit ted to the offlce of the surveyor-general at Santa Fe, New Mexioo, on warch 18, 1867. Here the petition remalned until 1879 when the surveyor-general submitted the petition to Congress recomending that only part of the grant be approved. 26

Desp1 te the request of the surveyor-general that the petition be "Bpeedily acted upon" by Congress there 16 no evidenes that this august body ever considered this title and 1t was st11l an "unconflrwed claim" when the court of Private Land Claima replaced the offles of the surveyorgeneral in 1891.

In 1904 the Court of Private Land Claims examined the. olain, as well as the report of the surveyor-general, but falled to allow most of the acreage embraced in the petition. Whis court reduced the amount to 5,024 acrea, which Ia almost exactly the aoreage which was designated as 1migable land.

Obvlously the people concerned as owners of the grant were displeased with the decision; and they finally eleoted

26. public survey ofl1ce, The San Higuel Del Bado Grant, Report No. 118 , F11e No. 49, U. S. Departient of the Interlor, General Land offlce, Santa Fe, New Mexico. The recommendation was for the approval of less than the full 315,300 acres. Attached to the petition 18 what was purported to be an original copy of the grant from the crown of Spain. 
to appen the case. To meet the nocessary lawyers' fees and other costs of the appeal sereral of the stockmen on the grant sold large numbers from thelr herds and flooks of 11 vestock. But the appeal nover got beyond the stage of securing the services of several lawyers. The clatm still remains at a 11tile more than 6,000 aores as it was surveyed in the Jear 1916.

Ao originally provided for in the contract with the erown, the grant was to be administered by a Board of prustees at first appointed by the Spanish provineial government and subsequently eleoted by the people. Thls Board, consisting of fire people leoted each two yoars, is still in extstence. Its chlef duties are looking after the legal aspects of the grant, oelng that the annual taxes are pald, and arranging that any bon1 Ide descendant of a grantee who comes of age is enabled to seoure a residential lot. Mo more Irrigable land can be distributed in this manner, alnoe all of it has been long aborbed by the existing people in the afferent vilages. As a result the land is now almost 100 per cent individually and privately owned. 2. The Anton Chico Grant: The Anton Chico Grant is located on the Pecos R1ver. It enbraces parta of southern San Miguel County and northern Guadalupe county.

This grant was originally given to a group of 36 persons by the Mexican government in 1822. According to the boundaries set down in the grant, the original claim embraced 
385,856 aores. 27 The 1 rrigable land in this grant was a1vided anong the families who were to cosupy the grant; and the other was designated as "common" land to be used in comon by the settlement "as mets thelr needs." The government of the village was to be by alealde and tom council. elected, as was the general practice, by the people.

petition for confirmation of this grant was made to the aurvegor-general in santa Fo coon after that officlal took orfice in 1854. After a brier examination of the olatm, which had been preserved by the grantees, the surveyorgeneral recomended that the grant be approved. This was . conflrmed by Congress in 1860 al though the acreage, after careful survey, was reduced to $278,000 .^{28}$

The population on the grant has Inoreased slowly. Anton Chico was still the only Fillage on the grant in 1844.29 As late as 1920 there were only three villages on the grant, anton Chico, D1112, and Colonias. In 1939 the population of these riklages totaled but 11 thle over 700.30 The grant is till owned in comunity by the bel $r$ of the original grantees. It 18 administered by Board of fire Trustees who are elected every two years. During

27 Donaldeon, op. o1t., p. 407 .

$28_{3011}$ Conservation service, Albuquerque, New Mexlco. Unpubl1shed data on a ourvey of the Upper Pecon Project, 1939.

29 coan, op. c1t., p. 305.

$30_{\mathrm{gol1}}$ conservation service, op. elt. 
reoent years the duties connocted with the job have ooncisted largely of keeping 1 t leased to outside stockmen and of seeing that the taxes are paid on the comon or pasture 1ande.

Although taxes on the 1 rrigated tracts of the Anton Chioo grant are pald regularly, the taxes on the common or pasture Iands frequentiy have been neglected in the past. since 1926 the probler of delinquent taxes on the common lands has beoome a serlous one. In that jear the tax laws of Hew Hexico were revised to make land subject to foreelowre for taxes del inquent for three yeara or more. Beginnting in that year part of the compon land was sold in large traots to outside stocken. These sales have continued unt11, In 1939, only 80,000 acres of the original tract still belonged to the people. 31

3. The La Joye Grant: The Le Joya Grent is Iocated in the now thern part of \$ocorro County, Hew Hexico. It embraces a tract of land that is almost blseeted by the Rio Grande River. Part of the area 1a 1rrigable but the main portion of it 18 not.

This grant was made by the Spanish governsent to a group of 67 familles, in 1819. Like most of the other granta of that time the 1rrigable land was to be divided

${ }^{31}$ Soll Conaervation, op. e1t. 
equally anong the ottlers and the pasture or grazing land was to be held in comon by all. The terms of the grant epecifled that "they were to maintain houses and arms in readiness to defend the caravang and wagon traing against host1le Indians." 32

The grant ras conflrmed by the Court of Private Land Cla1ns for Hew Mex100 in 1901. A survey at that t1me alIowed the grantees a total of 272,193 acres. 33 It was required that the grant be managed by a Boare of mmatees elected by the people. This organization is in exiatence at the present time.

The grazing Iands of the grant have been in continuous use by large atook men. At thes these stook men have been descendants of the original grantees and at other times they have been outsiders. At all times the grantees have been free to pasture any 11vestook they happened to have on the grant free of charge.

After title was confimed for the grant no provision was wade for the paynent of taxes. By 1920 delinquent taxes on the graxing or common land aggregated approximately

${ }^{32}$ Soll Conservation Service, Notes on Community-owned Land Grants in ie Mexico, U. S. Departiment of Agriculture, Ábuquerque, Te Hexico, 1939, p. 20.

$33_{\text {Publ } 10}$ survey offloe, The La Joya Grant, Report No. 95, Pile Ho. 169, 0. S. Departient of the Interlor, General Land offloe, Santa Fo, Wew Nox100. 
$\$ 23,000 .^{34}$ Realizing that something must be done to meet the demande of the county for delinquent taxes a tract of 10,000 acrea was sold in 1921 for a total of 18,500 . Although this sus of money was supposed to have been applied agalnat the tax delinquency there is no evidence in the county records to prove that thio was done and the people are very hazy about what happened to the money. 35 From 1923 to 1928 sone taxes on the grant were pald but the total, kept increasing by almost $\$ 5,000$ per year.

In 2937 the grant was offered for sale by socerro County for the delinquent taxes which, by this time, amounted to approximately 30,000 . It was bought by Thomas $D$. Campbell, the so-called "wheat king" for $\$ 76,000$ or about 35 cents per acre. Since this sale the people have been considerably agitated and have petitioned President Roosevelt to intervene and in some way grant them a loan with which they might redeem the grant.

At the present time there are approximately 1700 people 11ring on the grant most of whom are descendants of the original grantees. 36 As 18 the caee for most of the villagers in northern Hew Hexico the people living on the La

${ }^{34}$ County tax recorde, Socorro County, New Mexico.

35 Boll Conservation service, Notes on Commun1ty-owned Land Grants in New Mexico, U. 3. Departent of Agrioulture, Albuquerque, He Mexico, 1939, p. 23.

${ }^{36}$ Fron copy of petition of the grantees to the President, 1938. 
Joya Grant have long been dependent on other sources than the grant land for their cash living. llost of the men are farm laborere doing seasonal work wuch as herding sheep, thinning and harresting beete, and performing other fam work in the aurrounding states of Texas, Colorado, vtah and wyoming. However, they have clung to their small Irrigated holdings upon whioh they depend heavily for food to supplement the cash earned in wage work on the outside.

4. The Gangon de San Dlego Grant: The Canyon de San Diego grant is situated in Sandoval County, New Mexico, on the western slope of the Nacisiento Mountains. The Jemez River runs across the grant alviding it into two very nearly equal parts. The altitude of the lands in the grant is relatively high, varying in helght from approximately 6,000 to over 9,000 feet: 37

This grant was given of the crown of spain in 1798 to "the fomilies realding in the vicinity of Jemez Springs. 38 In 1860 the surveyor-general of New Mextco reeomended that Congress approve the grant. Th1s Congress did in the same jear. The acreage, as conplrmed, aggregated total of 110,000 of oozmon or grazing 1 and and 6,000 of farming land the greater portion of hion was Irrigable. Thls Irrigable

${ }^{37}$ Soll Conservation Service, op. clt., p. 6. ${ }^{3 B}$ Publ10 Survey orflce, The Canyon de San Diego Grant, Report Ho. 25, F1le Ho. 60, U. S. Department of the Interlor, Generel Land office, Sante Fe, New Hexico. 
Iand was reoognized as belonging to the individual families as provided for in the orlginal spanish decree. 39

Unt11 1870 the common land was used almost exclusivaly by the grantees to pasture their herds and plocks of Iivestook. At that t1mo, howerer, an outalde cattle operator named otero began to use the land in the grant as sumer range for his 11 restook. Gradually this cattle men began to buy up the Individual holdings on the grant, specifying with epch purahase that wh the sale of the individual holdange went the individual's rights to the grazing land. These purohases continued until his death in 1904. By this t1me he had begun to clalm the entire traot of common land for himaelf and to use it as if it actually were his property. 40

Soon after otero's death, in 1904, the helrs of the original grantees brought eult in the alstriot court to recover clatin to the grant. Under the direction of an able lawyer the clatas of the grantees were recognized by the court and the Pinal deolsion alloved the grantees 80 per cent of the 110,000 acres. Half of th1s went to the lawyer who presented the case leaving the grantees possession of the remainder or 44,000 acrem.

The court then appointed a commission of three men to

$39_{\text {Ibia. }}$

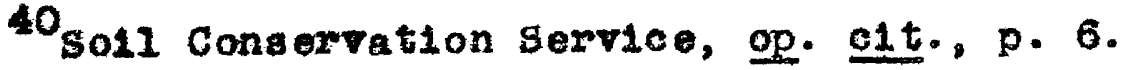


determine the best method of dividing the grant among the hetre. Th1s complasion declaed that, becalse of the difieul ty of dividing the 44,000 acres equitably among the heirs the tract should be sold in a single block and the proceeds difided emong these families that could establish valld clains to the grant. The tract was sold at public auction In 2908 at 45 cents per aore. This sale netted the grantees approximately 20,000 and the sum was divided equally among the 200 persons or famllies which were recogntzed as legal heirs. 41

At the present time in order to use the grant, the helrs of the original grantees must pay a fee of 25 cents per cow per ceason and 10 oents per season for a sheep or a goat. A charge of 20 cents is made for each wagon load of firewood that is hauled from the traot. If the wood is to be sold the charge 18 slightly higher.

From 1922 to 1932 the Hew Mexico Lumber and Timber Company cut approximately 100,000,000 board-feet of lumber Irom the tract. Although the lumber operations. on the grant decreased considerably during the subsequent years, the were continued on the tract unt1l 1936. By this time the trees sultable for making lumber had been almost completely cleaned out. 42

$$
\begin{aligned}
& 41_{\text {Ib1d., p. } 8 .} \\
& 42_{\text {Ib1d. , p. } 10 .}
\end{aligned}
$$


During the period of extensive lumber operations mentloned above work was avallable for the grantees in the Industry and at substantial wages. But with the dwindilng of the Industry more and more of the people were forced to aearch for exployment on the outside. At present they are following seasonal farm work in New Mexico and surrounding stater.

The Land Grant In 1ts Relations to Settlement patterns in gl Cerrito

The settlement pattern or manner in which the people are distributed on the land has long been recognized as an important factor in the social 11fe of farm folk. As Sm1th has sald, "the manner in which the rural population is arranged on the land 18 one of the most laportant aspects of rural soclal organization." 43 If the farm houses of a rural people are clustered together soclal contacts are I1kely to be srequent and intinate. If they are spaced widely apart the opposite 18 I1kely to be true, other factore belng equal.

New Mexico 1a one of the fow states of the United States In which the olustered or village type of rural settlement 16 a agnifleant part of the general pattern. Almost the entire Spanish-American population of the state is concentrated

${ }^{43}$ T. Lynn Smith, The Bociology of Rurel Life, p. 201. 
on the main streams and in mall, agricul tural villages. 44 . See Figure 5 and Figure 2. Th1s was the pattern dictated to all prospective colonists by the span1sh government which ilrst opened the territory for settlement in 1598 . and by the Mexican government which succeeded the Spanish Crom. As Blackmar has written, "there was, however, one distinct feature of the Spanish-American town whlch separated 1t from others. . and that was uniform1ty."45 In each village or settlenent the houses were grouped around the Plaza, the Irrigable flelds were just outslde the village and the common or pasture lands further beyond. Phis pattern prevalls today in EI Cerrito. W1 th the exception of three familles, which have built houses out on the once comonly owned land, thet they now fam, all houses in EI Cerrito gurround the plaza. Old adobe houses, barns, and sheds give ample testimony to the foot that 11ttle change has taken place in the settlement pattern of El cerrito since the time most of the houses were constructed, nearly 100 years ago.

There is 11 ttle doubt that the nature of the Spanish grant on which El Cerrito is located has been instrumental

${ }^{44}$ The agrioul tural viliage is defined here as a village "the bounds of which are more or less definite, and in which the population 18 made up predominantly of farmera and the ir families." gee Lowry Nelson, A Soclal Survey of Escalante. Utah, Brighan Young University studies 2, Provo, 1925, p. 3 . $46_{\text {Blackmar, op. c1t., p. } 161 .}$ 


\section{pogeq}

(Mgure 5. pustmibution of the rotal Population of Ner)

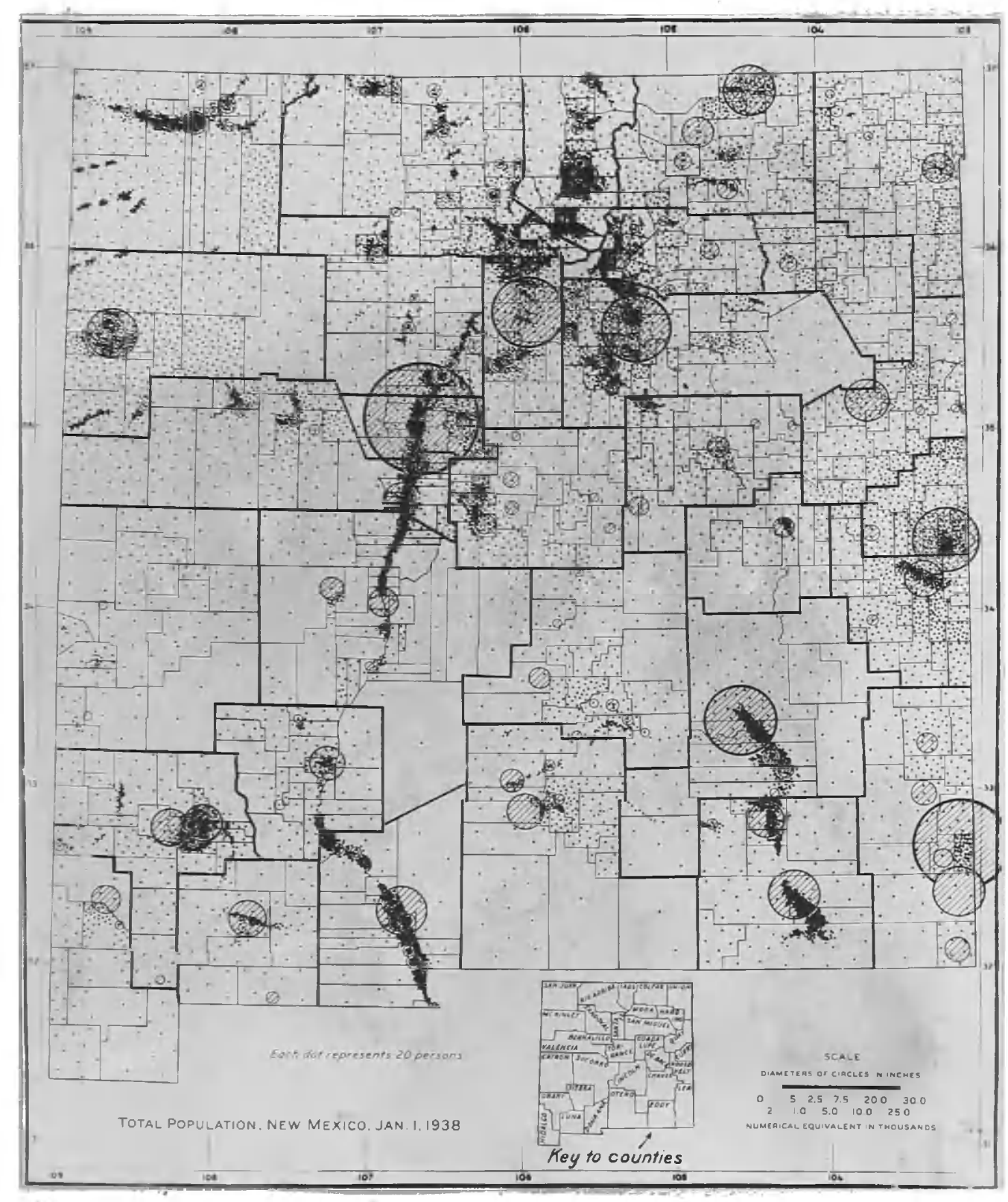

('gource-mureau of Agricultural Economios)

do not mal 
In perpetuating the original viliage pattern of settlement. The terme under which the spanlih grante were donated made 1t extremely difficult for an individual to move out on his own Individual bolangs unless he was in position to " round a colony after preseribed rules." 46 These rules would make it neoeseary for him to take ceveral fandiles wi th him and tablish a new colony.

The provistons of the San Miguel Del Bado Grant, on which El Cerrito 1s situated, explicitly stated that "the tract aforesald (grazing land) has to be in common." See Appenalx B. Conequently there tas no opportundty for a fally to move out on to 1 ts own holdinga as was the case In the western expansion of the New England colonies.

The terms of the grant also stipulated that the 1rx1gated land be distributed "to all who may occupy old settiement." Se Appendix B. This land, which in El cerrito represente a potentitil of approximately 40 acres, was equally dvided ong leriginal settlers. Living In clustered or wilage pattem on the 1rrigable land made for easy access to the Individual tracts of land whloh were farmed intensiyely and also made posstble acoese to the outlying grazing lands which were used for carrying on the more extensive 11vestock operations.

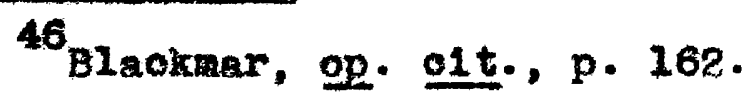


Al though nearly all the comon Grazing lands of the pooplo In El cerrito were lost in the decision of the court of Private Land Claims in 1904, the loss affected the econoxy of the village but little unt11 1916.47 for wany yoara use of the land remalned unrestrieted, since the disallowed portion of the grant had almply reverted to the fublie Domaln of the United States. In 1916, howerer, surveys of the Public Donain in the area were begun and the Iand surreged opened to ontry under the howesteat acts of 1862 and 1877 . A few of the El Cerrito fanilles filed for homesteads in the area but most of those flled for, and subsequently granted, were soon sold to outsiders. The provisions of the homestead law required residence on the olalm, and the Inhabitants of El Cerrito were loath to leave the viliage and establish perment homes on these tracts. Purthermore, none of the homesteads were oapablo of supporting a ramily unit. The seant grass covering on a 640 acre homestead, the largest acreage allowed, would support only a fow cattle or sheep; and no adequate water supply was arallable other than the few atreams in the area which were in large part controlled by the grants of land in the area which had been

47 As polnted out previously, El Cerrito is situated on a part of the San Miguel Del Bado Grant which was redused in 81 ze by the Court of private Land Clalms in 1904 from over 300,000 to about 6,000 acres. See Publlo Survey office, The San uifuel beI Bado Grant, op. o1t. 
allowed. Thus the provisions of the original grants served to "Ilx" or "set" the gettlewent pattern, and this manner of arranging the population on the land has remained largely unohanged. Families in the village continued to farm their Indiriaual, Irrigated holdings and el ther seek supplenentary seasonal work outside the village or, in case they had retalned a substantial herd or Hook of 11 restook, graze them on the surrounding and onve comonly owned pastures of the grant now leased from other omers. 48 By introducing and perpetuating the Spanish and Mexican tradition of the nucleated settlement pattern, these land grants have had a Iarge share in determining the relationships between the people and the land in $\mathrm{M}$ Cerrito, the upper pecos Valley, and, indeed, throughout all the southwestern part of the Un1 ted states.

The Land Grant, Survers and I1tles, and Land Div1sion in EI Cerrito

Both the Spanish and the frexican authorities used two * methods of dividing the land anong colonists. The common or pasture lands of the grants were characterized by "1ndiscriminate looation" with metes and bounds as boundaries. On the other hand, the cultivated or irrigable holdings were

48 questioning of the people in al cerrito rovealed that only o1x families have moved from the village and taken up permanent homes elsewhere. 
meamred according to the "riverfront pattem" where a number of varas were accorded each settler along the river or other atrean. 49 Beginning at the streams these long, narrow strips of 1rrigable land stretohed back, of ten to the tops of nearby mountalns.

As Indleated above, the bounds of the original grants were vague and inderinite. This fact it extrenely difIlcult, once the grant titles were presented for conplrmat1on, for the courts to determine the actual acreage covered by the grants, and where the IInes lay. In 1878 senator Thurman, Chairman of the Senate Connitter of Private Land clains, in a letter to the Becretary of the Department of Interlor, wrote that

the fact that the majority of these grants were never segregated from the public domain by aotual currey or measurement in the Fleld under the Bpanish or Hexioan Governments, but bounded by natural landmarks without reference to objects known to our publie Iand systen, it is Impossible for Congress to determine the quantity of land the clalmants are seeking. . . the oldinants prefer to obtaln a confirmation of their cla1m by metes and bounds wi thout regard to quantity. 50

The boundaries of the 1rrigable holding mere uaualiy, more derinite. At the time the settlers were put in possesalon of a grant a representative of the provinelal govermant divided the irrigated land among the settlers and

49 por discuselon of these systems of dividing lands, see T. Lyin Smith, op. C1t., p. 239. 50 Bonalason, gg. e1t., pp. 1137-38. 
measured the traots according to varas along the river front. Around these tracts were to be erected "mounds of stone. . so as to avold disputes." See Appendix Basting the survers on the river front and the fixing of manmade markers, wade this seoond wode of land division much Iess haphesard than the first.

The effects of the river-front pattern of land division. 1s obvious in almost any gpanish-American village of How Nexioo. The strips of 1rrigated land were neually narrow originaliy and the practice of further dividing the anong sons and daughters, who Inherit alike under Span1sh-Ameriean ouston, has reduced the trips in many villager to a few Jards In. Wiath. Th1s phenomenon is 111 ustratea in Figures 6 and 7 which show the holding in the Bpanish-Amerloan toms of La questa and Cerro respeotively, two of the most extrene eases in the state. 51

The diffloulties of Induolng the Spanish-American claimants of New Hexico to submit thelr land titles to the office of the surveyor-general of the Bnited states have been pointed out earlier. One of the main reesons for this seens to have been that the colonists attached 11ttle importanoe to the titles unt1l the onlted states took over the territory. Donaldson wrote in 1884 that "with paper t1tles of grant

51 phese viliages are situated in the spanish-American ares of the tate, juet north of the v111age of Taos. county ceat of paos county. 
Page $9^{5}$

136

Hot (Hewre: strip-holdings of Land in the village of La Questa, $) 0=18$

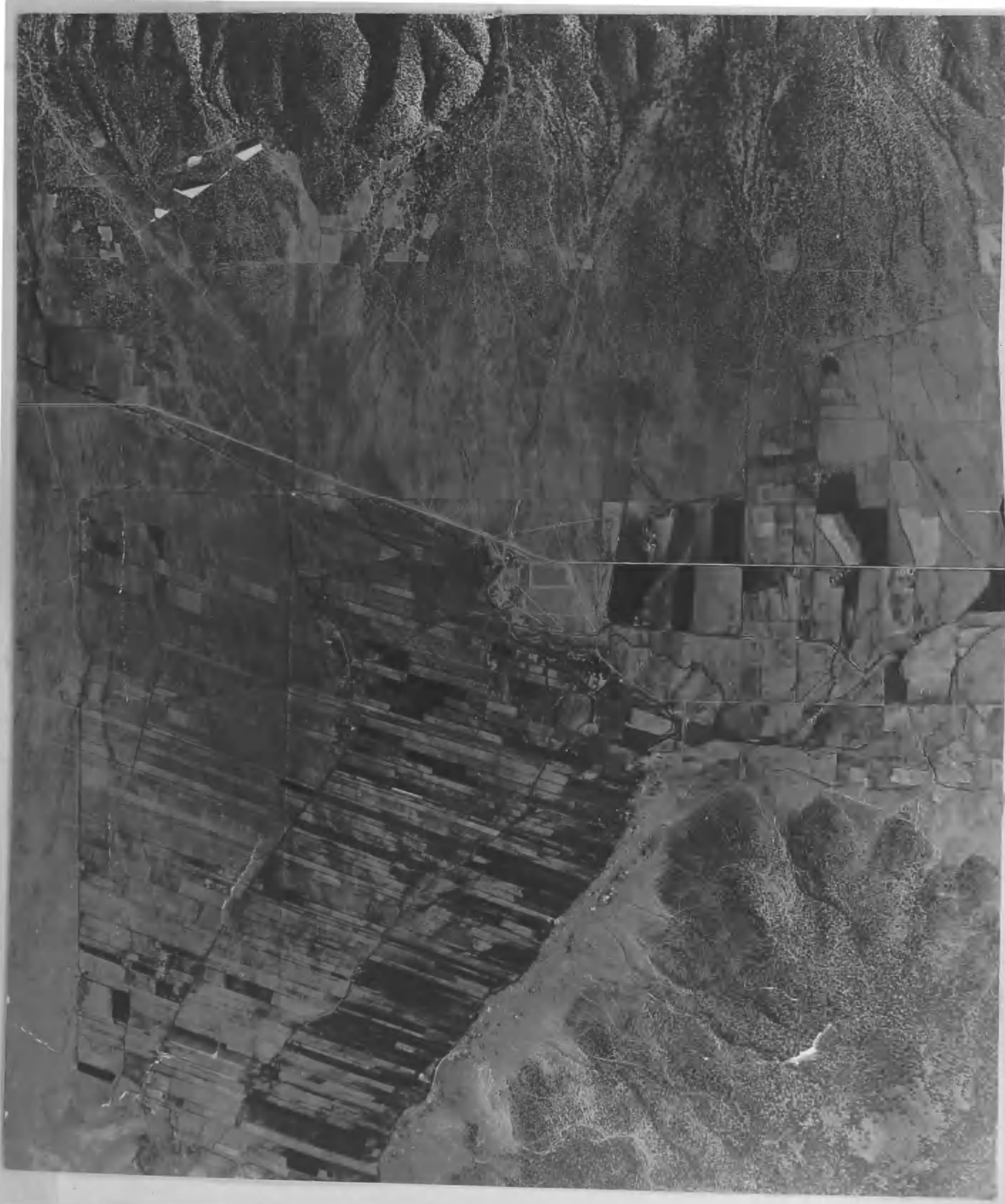




$$
\text { Page } 7 \text { q.9 }
$$

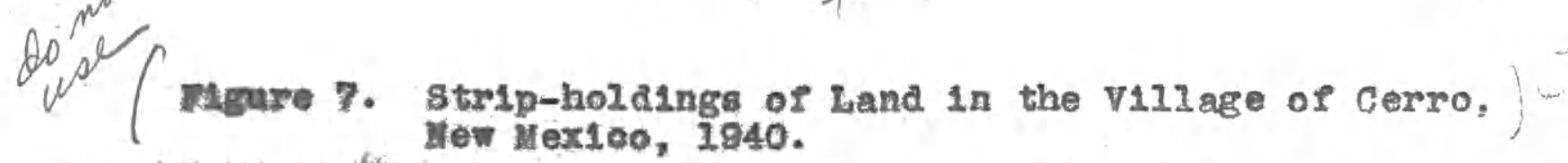

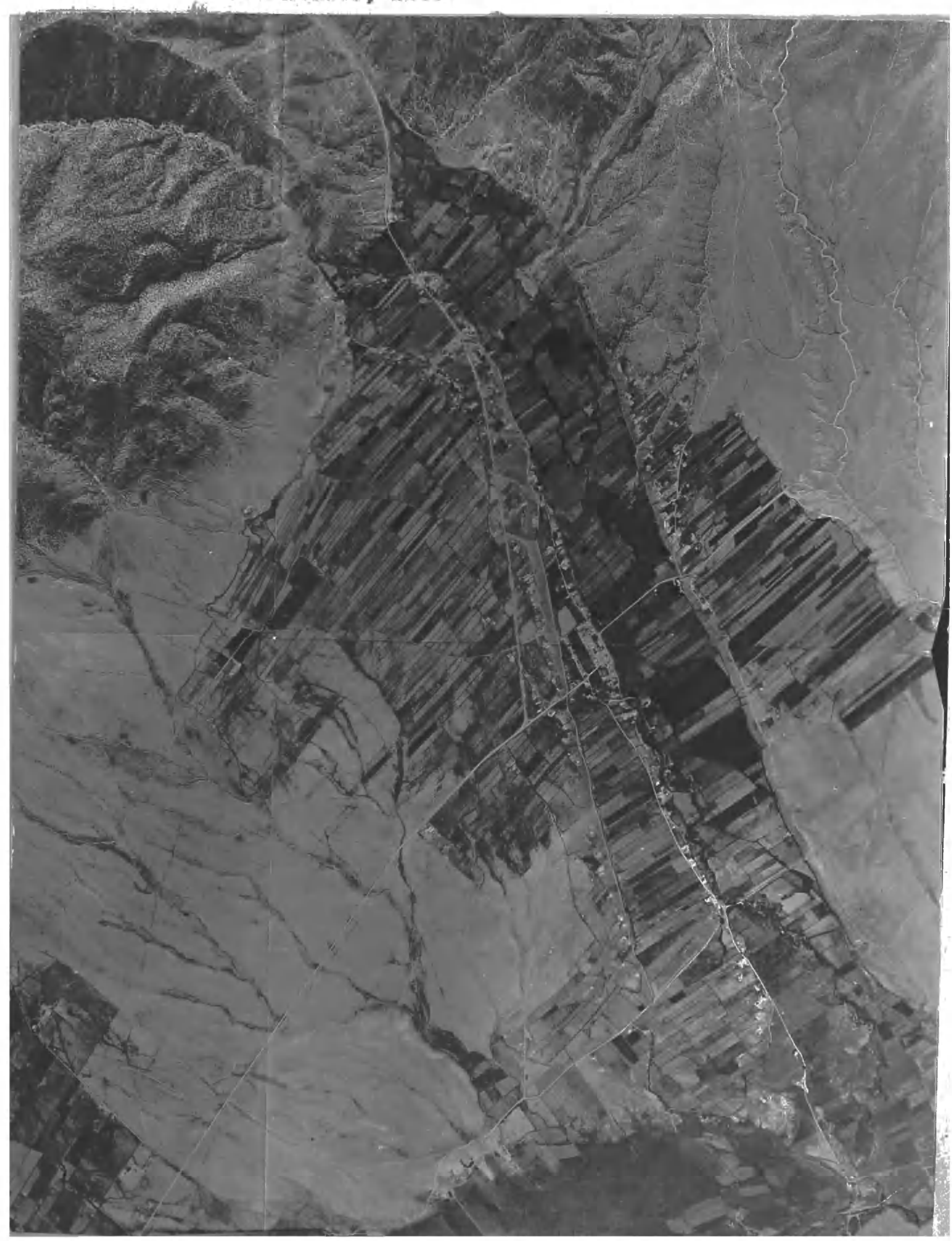


land beld by mea and women, otored away in old boxes or oarried about thesr persons, no one can form any estinate of the area yet olaimed in New Mexico or Arizona." 52

The effecte of the Inderiniteness of boundary IInea and oarelene surrogs, or none at all, characteristic of the Ipanioh and Mexican land grants acoount in large part for the extrealy heary loss of land by the Spanish-Anerican grantees artor the Ualted states took oror the territory. tho carelede way in which the decde were preearved added to these affioulties. There is I1ttle doubt that the office or survejor-general, and later the Court of Private Land clalme, attenpted to confirit aIl bonl flde granto but labk of titze papers, 1ndefiniteness of aereage in the granta, and disappearance of ortginel boundary markers for the

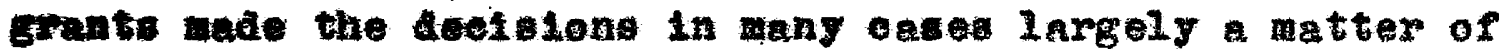
optuten.

In tew of the haphazard nature of the survers, divislens, and eare of papers, it it not surpriging that long befere the appenrance of the united states on the scene the Bpanteh-American area of New yexioo had boen inrolved in Inter-vilage and Intra-viliage conflicti over Iand. Some or these peralsted long after the origlnal oause was removed. Ther arose over boundary disputes; they persiated as aocially 1nherited feud. Until a fow years ago the 62 Bonaldson, ㅇ․ 요t., p. 406. 
people of EI Cerrito were Involved in one of these boundary alsputes which, at one time, reached such a peak of intensity as to result in the death of one of their residents and the wounding of several others.

Fortunately for the people of New Mexico the "floating land grant typieal of parts of the Spanish-American area never provalled to the extent that it seems to have in other sections of the Spaniah colonization territory. 53 This seems to have been in large part the result of the fact that fower Indiviaual grants were given or sold in New Hexico than in other territories such a callfornia. Some of the Individual granta did "noat about to a certain extent, however, as in the esse of the faxwell grant, whlch, from tine to time, threatened to displace several hundred settlere as a result of re-surveys and clalns recognized by the courts. 54

The consequences of the Spanish land system of indiscriminate location and indetermanate survejs are readily evident in the land belonging to the people of EI cerrito today. Grant land belonging to the villagers 1s spread out In a pattern wuch reambling the state of pexas. See pigure 4.

53 The floating land grant was a term applied to a number of grants that kept changing, usually enlarging, thelr boundarlea each time it seemed legally posblble to do ao. See Henry George, Our Land and Land Pollcy, New York: Doubleday, Doran and Company, Ine., I9IT, pp. 39-40.

54 Dunhar, op. c1t., pp. 212-241. 
In eome respects it resenbles "an amph1 theater-- the buildIngs (and land) ocoupy low porition... bounded by the ourrounding hi1le..55

However, the Irrigated holdings of the EI Cerrito people, with few exoeptions, still retain the reotengular pattern which 16 oharacteristie of river-tront land division. Due to division of these holdings, and then re-division from generation to generation, many of these holalngs are now no more than a few yards wide. Some of them are so narrow that they are no longer fenced a a fenco would make it extrenely diffleult, and in a few onces lngossible, for a person to turn a pair of horses around in cultivating or plowing his holding. See Figure 8.

Tities to these tripe of land have seldom been recorded by the people of $\mathrm{El}$ Cerrito. Instead, providing such tit ties exist, they are kept in trunks or boxes at home. Naturally many of them have becone misplaced or destroyed. Thla careleasneas with documents has contributed greatly to consusion in property rights.

The indefindteness of location in the Spanish land aystem is a factor in the present inability of most of the EI Cerrito families to estimate accurately the alze of their holdings. The people know, falriy definitely, how many varas they have on the river-pront and where the boundary

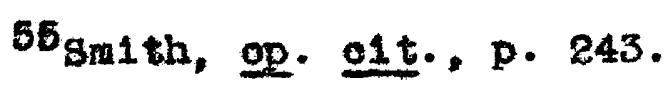


warks are but if asked about the acreage in thetr Irrigated holdings w11l give an estimate and qualify $1 \mathrm{t}$ by the stock expression poco mas o menos.

Thus the land situation as it exists in El Cerrito today, characterized largely by mall Irrigated holdings ourrounded by grazlng lands lost as regult of poor thtlos and Indefinite boundaries, reflects to substantial degree what has happened over the Spanish-Amertcan area of New Hexico and, to bome extent, over the entire area of the Southwest. It 16 an example of what can happen when a system of socurate survers, dorint te t1ties, and permanent bases for location are super-imposed upon aystem characterized by careless or lack of aurveys, ambiguous titles, and Inderiaite locations.

The Lane Grant and Land Tenure in El Cerrito

Land tenure has been characterlzed as "a social relationehip between the population and the land."56 In this sense the term connotes the rights an individual or Individuals may hold in the land and the manner in which it is held. Under this definition land tenure beoomes one of the most Important factor involved in the otudy of mural farm 21 fe.

As pointed out earlier, the Spanish and Mexican

${ }^{56}$ gm1 th, op. c1t., p. 260. 
oomunity land grants conferred title to the comaron or grazIng lands to group of fantlies in common while the 1rrigable land was paroeled out in traots to individual fam1lies. The coman Iands were considered to rematn under the full ownershlp of the crown under Span1sh authority and to the Republ to after Mexican oecupation. The irfigated holdings, on the other hand, might usually be disposed of by the ownerg after a speclfled number of years set down in the settlenent contract. Se Appendix $B$.

This pattern of dual ownership of land prevalled in il Cerrito unt11 1904. In the contract of the original gettlers th the spanish crown the tract aforesald (grazing lands) has to be in common, not only in regard to thenselves but also to all settlers who may join them in the future." Pitlo to the grazing lands was placed in the hands of the Board of Trustees and each fanily was given en individual titlo to a tract of 1 rrigated land and a residential lot. Under this system of dual ownership the people of 1 Cerrito developed pergonal interest and attachment to the irrigated land that was never approached in their interest In the grazing lands. Thta observation 18 substantiated in the four case histories of grents given proviously where taxes on the grazing lands were often delinquent but eldow on the Irrigated Iand. Today in BI Cerrito families thet own tracts of the once common grazing land acquired under the homestead acts often have them mortgaged or will sell 
thea, but none of the 1rrifated holdinge carry any financial encumbrance.

Al though the corrito fantlles were allowed oqual use of the comon lands thls seems never to have been the case. From the beginning of the wettlement unt1l the common land was surveged and removed from the uae of the viliagers the land seeas to have been largely used by two or three large livestoek operators in the village. All other fanilies proVlad labor for these Ilrestook operators and perhaps grezed a tow sheep or eattle for themsel ves. 5 ?

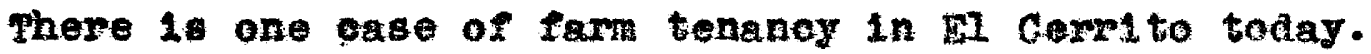
In this 1nstance the tenant is a part-owner bince he has his irrigated land in the village and approximately throe ocotions of grazing land on the mesa. All the rest of the fam111 ed in the 11 lage are fam-omers, of more accurately land omers, since they each have a titie to a residentlal lot, and all but two, titlo to a plot of Irrigated land as pell.

57 Out of this o1 tuetion grew the partido systen of share-cropping sheep. Under this system the large sheep ownere rent large numbers of shoep to mall operators. Under the contract binding the parties the renter $1 \mathrm{~B}$ bound to return a specified number of lambe each year (uaunlly around 20 of apecified minimum welght) to the owner and 16 also obligated to return the same number of heep as rented at the termination of the contract. The renter also egrees to bear all expenses incident to the keeping of the shep. This systen of renting sheep is practiced pidely - ver the Spanish-American area of New llexico. The fact that 1t 18 an old syatera 1s evidenced in 1 ts mention by Joseph Gregg, op. e1t., p. 122, as early as 1844 . 
Thus the traditional practice of making each family on a Spanish or Hexican land grant an owner of at least a small portion of land acoonts, in large part, for the high degree of land ownerghip existing today not only in $\mathrm{gl}$ Cerrlto but throughout the entire Span1ah-American area of New Mexico. This phenomenon has other connotations also which will be discussed in detall in the subsequent pages of this work.

The Land Grant and size of Holdings in El Cerrito

The $81 z e$ and distribution of land holdings is an 1mportant ractor to consider in any atterapt to understand the cocial 11fe of any farm people. Not only the economie status but the soeial status of a people as well 18 in large part determined by the extent to which the land is divided among the familles, 1.e., whether the ownerahip of the land is somewhat evenly divided or is concentrated in a few hands. Although the size of the Spanish and Mextoan land grants was I1mited by law to not more than eleren square leagues of land this Iimitation was not effeotive in practioe. Due to an absence of ourveys the boundaries outlining these grants of land were frequently found upon accurate survey to enclose everal times the amount prescribed by law.

After the United States occupled the territory of New Mexico the office of the surveyor-general, and later the Court of Private Land Claims, were inetructed to recognize 
the 1ze Ilmitation set down in Spanish and Mexican law but for sone reason, that is not at all clear from the records, Prequentig these instructions were ignored. 58 The most flagrant riolation of this Iisitation in the territory of Nev Hexico was in the Instance of the Haxwell land grant which, when confirmed, contained well over a milion acres. 59 It was not at all unusual for a grant of more than 100,000 aores to be reoognised. The San Miguel del Bado Grant, on which the Village of El Cerrito 16 situated, contained more than 300,000 aeres in the original claim.

Evidenee of the once vast spanish and texioan land grants still remains in wew Mexioo. In the predominantiy Spanish-American area of the state today (the elght counties show in black in Figure 2) the majority of the farns fall Into the categories of elther largo or amall farms. The 1940 Census of Agricul ture shows that in the eight countles of Hew Mexico where the population was over 76 per cent Span1sh-8peaking In 1938, about 7 per cent of the faras contained 1,000 aores of land or over. On the other hand, 55 per cent of the farms in the area contained less than 30 acres. Th1s flgure would have been conslderably larger had the Census counted all irrigated holdings as farms since

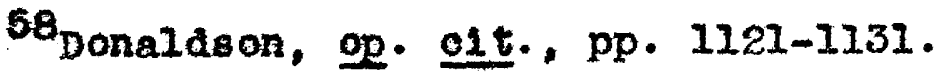

69 Dunham, op. c15., pp. $212-241$.
} 
many of the holdings of the Spanish-Ameriean fantlieg are 1eas than three acres. In the village of FI Cerrite the irrigated holding averaged less than two acres. See Table II.

Only two familles living in El Cerrito in 1940 owned more than a thousand acres of land. Bee Table II. Thile the average acreage of grazing land, for the famll1es reporting owned grazing land, was 172 acres the median aores owned was only 42. Nany of these traots are so poor and inacoessible as to be practioally ralueless to the owners. The irrigated holding also are pitifuliy 1nadequate. The a rerage for all fatilles reporting irrigated land owned was under two acres. Some of the holdings were no more than $1 / 4$ aore in extent.

Bach of the 20 famllies living in El Cerrito in 1940 owed at least a residential lot and 18 of the 20 owned Bome irrigated land. Se Flgure 8. Over a perlod of years these holdings have tended to become coneentrated in a few hands. As Flgure 8 indlcates geveral familles have acquired from two to three strips of this land while one family now owns seven. 60

It should be evident from the data and discussion given, above that the Spanish and liexican land granta introduced a

60 These comblnations have come about through inher1tance. It 18 extremely eldom that these strips of land are sold. 


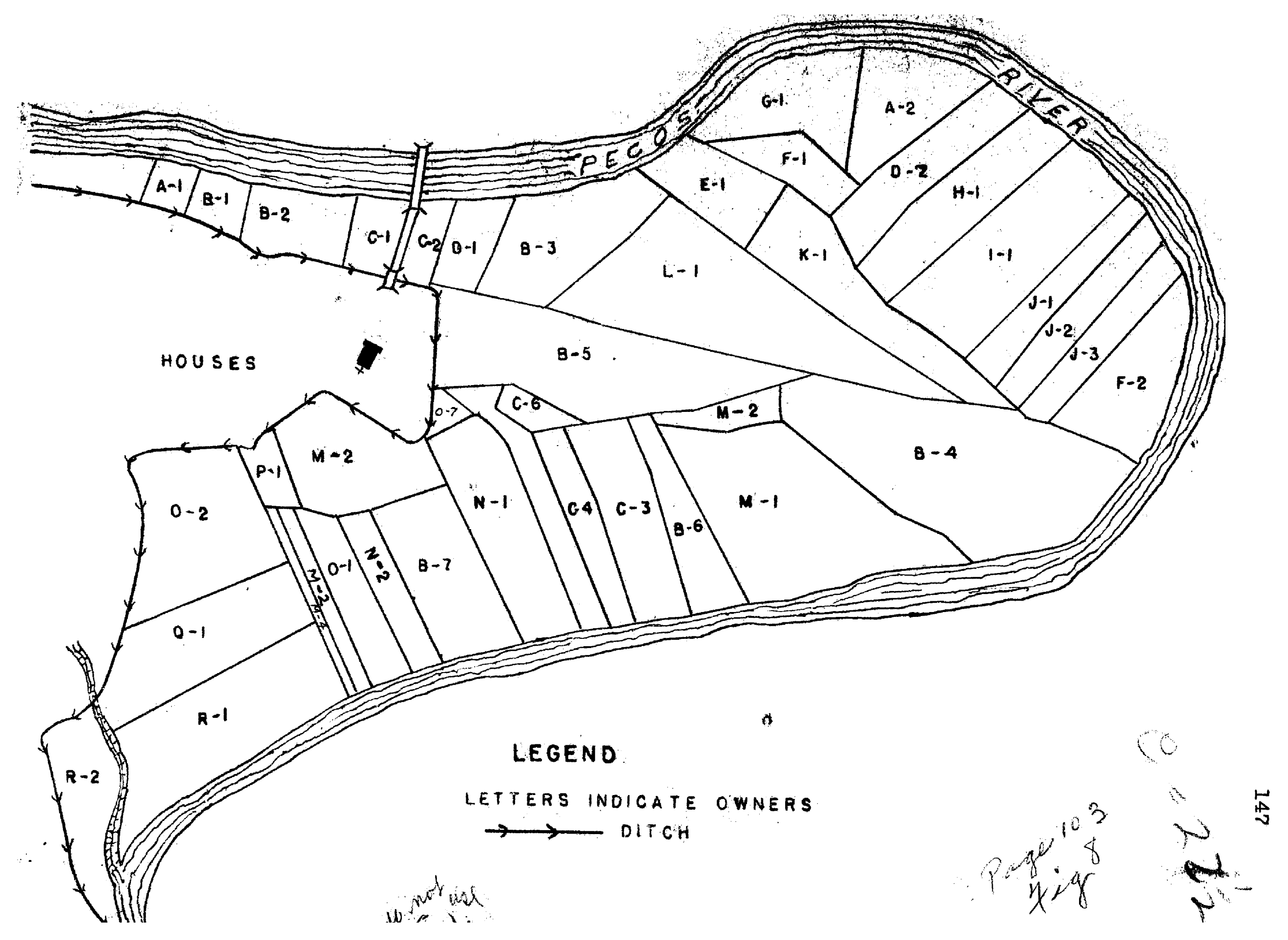


pattern of land holdings in Hew Mexico that st1ll prevalls to a great extent in 181 Cerrito as well as the SpanishAmerioan area as whole. The individual, irrigated holdings still are to be found in EI Cerrito conmunity and the Upper Peeos area much as they ald during the Spanish and pexioan regimes. The principal changes in these holdings since oceupation of the territory by the United states has been that they have grown smaller and come into the hands of a greater number of owners. The extensive comon holdings, on the other hand, have largely been lost to the use of the Spanish-American population. In size and number many of them still exist but are now owned by outside and largeoeale ifrestook operatorg who have come into the area and bought then as they were offered for sale.

This shift in the pattern of ownership has been a tremendous impact upon the economic and soolal behavior of the people affected. Sere phases of this change w11l be alsoused in the later pages of th1s study but 1 t might be concluded here that significant soclal and economic adjustments are yet in process in the area as a reaul of the new restriotions in the use of the once commonly owned lands. As an exanple, the people are unable to understand why this land has been removed from thelr use, why they now have to pay a set charge even for flrewood removed from the land. They have been unable to rully comprehend the signifloance 
of new barbed wire fences that 11 terally enclose them in their sall village holdings. Who owns the land, the people w11 tell yoa, doeen't matter but for en ownes to restrict these lands to individual and private use 18, for thos, a new and extrenely unpleasant experlence. They are now caught in a situation in which thelr irrigated holdings are too small to provide a living, while the lands onoe used in comon have become the private property of persons outside the village.

Land Grants as a Conditloning Pactor in the Pural Social Processes of El Cerrito

Ho analya1s of group Iif can be complete wh thout deroting sone attention to the basic 8001 al processes by which ilfe in the group goes on. In the following pages an attempt is made to lsolate certain of the basio soolal procesees in the village of $\pi 1$ Cerrito and to point out how these processes have been conditloned by selected environmental phenomena, namely the Spanish and Mextcan land grants.

1. Coapetition, Conflict, and Cooperation: Opposition and cooperation have been defined as the two Pundamental forme of social interaction. 61 out of these two basic

61 Kimball Young, An Introductory goolology, New York: The American Book Company, 1934, p. 348. See ai so T. Lynn Smith, op. o1t., p. 433 . 
processos arloe all the others. Evidence of the funotioning or ench process is abundant in the Span1sh-American area of New Mexico where an eoonony of scarcity has made cooperation expedient and an intimate and elosely woven pattern of soolal contact has ade confliots ineritable.

The nature of the contracts secotapanying the Spaniah and fexican land granta made cooperation between the 1nd 1 vidual families in a new settlent mandatory. There was always a certain amount of work tipulated in the contracts that mut be done in common as "the conatruction of their Plaza as well as the opening of altches, and all other work that may be deened proper for the common welfare shell be performed by the comunity with that union which in their government they mut preserve." See Appenasx 8 , This form of cooperation has been designated as "labor in comon" ana played a major role in the early 11 fe of the Spanish and Hexican colonies and to a considerable extent exis to in the Spaniah-American Villagea of Hew Mexico today. 62

An exemplo of this "lebor in common" form or cooperation in El Cerrito is the "DItoh Association" an organization that has a history as old as the village 1 tgelf. The function of this association $1 \mathrm{~s}$ to clean the irrigation ditches once each year and to make any repalro that may

62 1111 an F. Ogburn and Meger F. N1mkoft, So01010gy, New York: Houghton M1felin Company, 1940, p. 345. 
boove novesery during the year. Th1s association 18 headed by "ditoh bose" who is eleoted annually to gupervige any work on the 1rrigation system. The alteh boss does no work himself, his sole dut1es bolng of a supervisory nature. The actual labor is performed by the members of the association. All farmers operating 1 rrigated land are members and mut report for work at any tine the alteh bosa calls them out or else pay the group for doing thetr share of the work. The Informal aspects of oooperation In fil cerrito are much more pronounced than the formal. Through years of interdependenoe the people are conditioned to call upon nelghbore and relatives for many types of assistance and, in turn, are expected to reciprooste when the need arisee. Any tesk that requires greater trength or physieal effort then a single farily can aupply 18 solved by calling in one or more nelghbore. Wany of the cooperative affalra alwost have beeowe social ovents as when severel fanilieg are oalled in to help butcher a hog or ereet the roof of a new house. It 1. not unueual for suoh events to be attended by far more farmiles than could posalbly be of assistance unlese they work in turns. The village type of settlement wheh prevalls greatly fac1litates this typo of mutual ald.

Any personel misfortune a famly may experience in DI Cerrito 18 shared, in so far as possible, by neighbors, relatives and friends. In case of serlous lilness there is never a lack of volunteer men and women to help. In case of 
death each adult in the village apends some time the "wake alvays given at the howe of the deceased. There is a great deal of borrowing and lending in the village also and there is coldan a complaint sor fallure to repay the loans. Th1s is true in the village al though town merohen to frequentiy point out that the reverse is frequently true in their dealinge with the same people.

The deseription of the these cooperative notivities could be contianed at length. Here 1 t 1 s important to point out that the aature of the original grants and the settlement types established under their terus have been of great slgnifleance in perpetuating the ooperative activitiea. There 18 also ample evidence to oupport the thesis that the nature of the Spanlah and Mexican land grants have been a strong factor in promoting both 1ntre-pillage and inter-village eonfliot. Bibutes over grant boundaries, tendencies on the part of some few fanilies to monopolize the grazing lands, water supply, and other resoureen have often developed that still persitit in the Spanish-Anerican villages long after the source of grievanoe has been rem moved. Representatives of various governmental agencies operating in the spanish-American ares frequentiy givo oxamples where operational efficlency has been sacrifloed in order to please existing village factions. For example, during recent years the Soll Conservation Service has en- . Aeavered to combine many of the gmell lrrigation ditches 
Into larger and more efflotent canals only to f1nd that the villagers refused to cooperate. Such combinations pould make it necesary for strong intra-viliage factions to work together.

The history of one of these confliets in El Cerrito well 111 ustrates how intense such conflicts may become. The following story 16 a a resident of El Cerrito told $1 t$.

The v1llage of EI Cerrito was settled by the $M^{\prime}$ and my people (the $Q^{\prime} g$ ). They canse in alnost equal numbers, just about as many $\mathrm{M}^{\prime}$ as Q's. Both fanllies had some money and large numbers of sheep and cattle. At flrst there was no trouble between then. All were friends, al though only one marrage ever took plnoe between the two fanilies. The 1's used to herd their stock on the north side of the village and people herded theirs on the south side. But as the herds kept getting larger

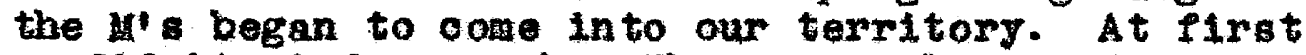
we didn't mind so much. There plenty of grass and we didn't want to have any trouble with them. They wore mean poople. They were always gotting drunk and plghting among themselves. Finally we had to tell them to stay out of our territory. Thls made them very angry and they began to do things to us. Sometimes they would take our calves and lambs and brand them with their own mark. Thinge got so bad between the families that they would not speak. Then Pights began. Finally one of the rif hit ay grandfather over the head wi th a shovel and almost k1lled hisi. My uncle ran for the aheriff but the $M^{\prime}$ s followed hin and almost beat hin to death. Th1s made my father very angry. He took his gun and shot one of the M's. He didn't die but he was siok in bed for a long time. There was a big trial after that which lasted for a long time. It was a rery expensive triel and cost both families almost 821 the sheep and cattle they had. The Mf $^{\prime}$ were left in such bad shape that they all lept the village, and our people wore never able to get back their property.

obviousig, the statement that "because of 1 ts deep and asting slgnifloance to Ilfe, land has been the cause of 
some of the grestest conflicts between the nations of the rorld, and between the people within these nationg" has been true for the Spanish-American area of New Mexico.63 such conflicts as that described by the resident of El cerrito have all too often ade the Spanish-Amerloan people easy prey for those who have been willing to take advantage of thia weakness. So intense are many of these conflicts today that the particlpants would wuch prefer to lose thelr remaining resouroes rather than Jo1n hands and at taok their common economle problems in unison. This situation has been one of the primary reasons why "the surdy Anglo-Saxons overpowered and dominated the Spaniah people, who long before Migrated Irom the mother country; and now within the boundaries of the United States are slowly absorbing or crushing the last remants of the institutions of this romance people. Podey the Anglo-Sexon exul ts in the treng th of a predominant and united nation, whil the Spaniah-Azerican yet within our borders deplores the fallure of hls people, and reflects on the 'buenos tienpos' of the Spanish occupation." 64

2. Locomodation, Assimilation, and Acculturation: As. It has been aptis put, if social ilfe has 1 ts confliots, it 1so has 1 ts adjus taents." 65 . Such adjustments have not been

${ }^{63}$ Carl c. Taylor, Rural Soclology, New York: Harper and 3rothers, 1933, p. 110.

64 Blackmar, op. o1t.. p. 6.

${ }^{65}$ ogburn and N1mkoff, op. c1t., p. 369. 
Lacking in the village of El Cerrito nor in the much larger 3panigh-Amerioan area of New Mexico of which mI cerrito is a fairiy typleal segment. Flrst, there wero adjustments to " be made as the result of coming into a new physical environnent and I1ving in contact with otrange people, the Amerisan Indian. Later, the enterprising Anglo entered upon the seene bringing with hiza new oulture to whioh the spanishImerlcan today is st111 adjusting hinself.

At the time of the Bpanish occupation of the present . itate of New Hexico the position of the Spanish colonist In reepect to the Indian was definitely one of domination. that whloh the Indian had and the Spanish conqueror wanted, je It Iana, goods or women, the latter took; and better ireams and more highly integrated forees were usually iufficlent to make the aoquisitions permanent. The Spanishmerlcan taught the conquered Indian his rellgion, language nd the comon arte, agriculture, and the praotice of alsing cattle."66 on the other hand, he learned from the onquered Indien how to grow and use such cropa as com, otatoes, beans, squesh, tomatoes, ch111 and others. 67

W1 th the arrival of the Anglo in New lexico, howerer, he al tuation of the Spanish-American was reversed. Subrdination and not domination came to gall him. No longer

\footnotetext{
66 Blackmar, op. elt., p. 116.

67 ginth, op. 01t., p. 500 .
} 
Was he the conqueror but the conquered with all the usual Implisations that go with suoh a status. Under the Impact of the contaot wh the aggresalve Anglo the Spanish-American began a retreat to a position that has, from both an economic and soclal standpoint, beoome teadily more preanlous. As. Blackmar has sumsed up the Iand situation of the SpanlshAmerican, "The arlginal holderg of lands have lost most of tholr holdinge e1ther through the m1s-judgments of the sourts and complssions, or else by the wily intrigues of the Inglo-Anerieans, especially the latter. The Hexican has seen no matoh for the invader in business thrift and jroperty cunning." 68

As in the case of the Spanish and Mexican colonista tho borrowed heavily from their Indian predecessors, the inglo too has adopted many elents of the Spanish culture. llackmar, in his excellent work on Spenish Institutions, lab 118ted some 35 Spaniah words which have come into genral usage in the southwest. 69 other borrowed tral to are brlous to anyone taking a trip acrose the Southwest, inluding such items as: adobe construction of bulldings, penish architecture, wide varlety of foods and methods $f$ preparing thew, and many others too numerous to mention ore. Above all, for the purpose of this treatise, has been

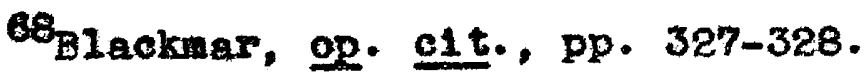
69101d., pp. 271-279. 
the tendency on the part of large Anglo stockmen to take ivar the Iand grants given to settlars by the Spantsh and lexiean governments as well as the original methods of perating them.

As pointed out eariler, the people of El Cerrito were. lut 11 ttle affected by the change in government of the ter1tory of New Hexico until the adverae declsion of the court I Land Clalms in 1904 . whioh took away thetr comon or grazng 1ands. Actually, the rull meaning of the decletion was . ot realized until as late as 1916 when gurveys of the land ore begun and homestead began to spring up all around hea. Then this oltuation was fully developed there was no Iternat1ve for the people but to rely on outside employent. Thus a pattern of seasonal work and seasonal migration egan for these people whioh has continued to the present. ach eeasonal work-peak w1Il now find all but a few of the dult males of El Cerrito away from the village in one of he surrounding states.

W th the increased contacts the Spanish-American people" re having with the Anglo culture, brought about largely rough enployment, trade relations $w 1$ th the towns, and arough the ohools, it is obvious that the oulture of these rople 1 s slowly breaking down. This fact 1s recognized by te people of El Cerrito as well as by the Span1sh-American ea as a whole. Many of the people are frank to admit that ley would like to see the transition made as quickly as 
10salbie.

Aetualis there 18 considerable appreotation of the nglo and his oulture in EI Cerrito. An Anglo fan1y that noe I1ved near the village is mentloned quite frequently wd the faraing practioes of this family have boen adopted ocally to a lindted extent. Many of the El Cerrito fam11er stated a bellef that the vilage would posgibly beneit ron having a few progxesalve Anglo farmers nearty. It ould facilitate practiee in the use of engligh and, some hink, might afford an opportunity for the peoplo to learn omething of the techniques that have made the Anglos so nocessul in thetr push into wew Mexioo. It is admitted, orever, that such a situation coula be dangerous to the cople' B interests. Such fanilles might manage eventually. - get possesaton of their remaining lands, possibility hat has become an actuality in many other parts of the tate.

Al though a catiafactory pattern of acoomodation has oen worked out between the Spaniah-American and Anglo of aw Ilexioo these two peoples remaln separate and diatinet roups. It is extremely seldom that the two group interIrry and in the rare Instanoes when this happens elther 10 Span1sh-Ameriean or the Anglo is taken into one of the roup and almoet excluded fror particlpation in the other. 1 mumary, 1t might be ald that a complete pattern of IJustment between the two groups has never evolved and WII 
ot until elther a pattern of coerolon and domination, or I8e equality, Is generally recognized by both groups. Some I the factors that w111 enter in the adjustment have been 1seussed previously and others wil be disoussed in the absequent pages of this study.

3. Soolal Stratifioation: The Spanish-Amertean area I New Hexico is no exception to the statenent of an eminent octologist that "any organized goolal group is always a tratifled soctal body." 70 since the rirot group of Spanish Dlonlsto settled in fow Mextoo in 1598 a elas hierarohy 18 existed that has ranged in holght from Spantah noblemen 3 the lowly peon and slave.

During the early stages of Spanteh colonizetion in ow extoo social tratification among the population was 1 te peak. At the top of the class pyranla were the fer sanish noblemen and offletale who had bought or had been Iren huge tracts of land which they had pledged the orown J gettle. These grandees "were Prequently men of high ink, in whose reins flowed the best blood of castile. The ld Castilian, showing disdain for the Mexican and his Inguage, took great pride in his own language and pedigree."7l : the bottom of the pyramid were the Indian peons or slaves

70p. A. Sorokin, Social Mob111ty, Hew York: Harper and othere, 1927, p. 12 .

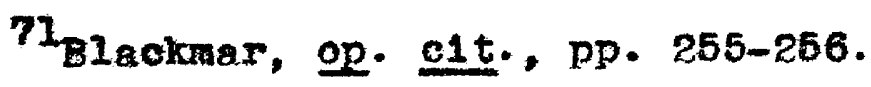


wo were under the "proteotion" of the grandees. In the ldale lajers of the pyramid were the "settlerg" who had oen given gall traots of 1 rrigable land and large acreages f grazing land to pasture in comon.

Al though the Spanieh grandees and their progeny gain-. laed thelr places at the top of the soetal pyramia until Pter the United states took orer the termitory the1r laces soon cave to be hallenged by a new type of grandee, type that depented upon proporty, mainly sheep and cattle, ir a olalin to conlal oninence rathor than upon Cast1lian Lood and a type of 118ping Spaniah.

This new type of grandee grew steadily in numbers. By Ir means and foul his herds and nooks increased unt11, 1 most of the spanish-American villaged the compon of grazig lands wore belng ased by only a few famlites. Although ing of the grantees would retaln a few sheep or oattie ist of the Iivestook becane concentrated in a fer handa. ese big 21 restock owners were known as the patrones of the Ilage upon whom the majority of the other families pended for work.

可1 th the coming of the United stated Into the territory, " wever, the patron as an Important figure in Spanish-Amer1n I1fo began to docl1no. Ho was no matoh for the Yankee buginess deals and with the shift in ownership of the nd base went the 11 restook enterprisee of the patrones. th the exeeption of a relatively few who were shrewd enough 
3 keep their resources intact or who had converted their Bouroes into more lucrative channels the patrones lost at and became anall farmers, merchants, or petty pol1tleians. The rillage of El Cerrito has passed through the atages f social change noted abore. The older 1nhabitants of the IIIage st111 rereaber the two patron families of El Cerrito ne of wheh still lives among then. The people still talk f the vast holdings of these families and how they would atertain with elaborate flestas and always provide work or porlsions for the poor and needy among them. "Those were se good old days," the people will tell you, "when we were rosperous and Independent." Host of the people are hope21 that the government w11 some day return their lands and 2ey w1ll be able to live again as they did before the comIg of the Amerieanos.

Although class differences still exist to a Iimited ctent in 21 Cerrito the bases of distinetion have undergone zange. In the f1rst place economie distinction in the vilge is at animure. Only one fanily in the village owns id operates any significant amount of I1restock and in this lse only enough to supply labor for his own famlly and arhape a few dsys of work to othere each year during the lak labor season. Seoondly, blood relationships in the .11age have become so wldespread that almost any resident in elaim at least a second or third cousin relationship to eryone else. 
Thus in El Cerrito, as in the entire Spaniah-American of of the state, the social pyranid has become somewhat attened out. Such factors as age, family history, whether - not a man 18 " good apeaker" or clever politican are aracteristios that carry some prestige value but, by and rge, the people are primos and are of 11ttle social disnotion one from the other. The exceptions to this are the soendants of the old grandees who olatm to have remained art from the rabble and maintalned thelr castilian blood d chlldren of the patrones who have managed to hold on to eir property. A few of each of these may st1ll be found many of the Spanish-Ameriean villages and towns of rthern Iew hexico. By and large, however, the Spanisherlcans have become categorlzed a a group of small fam ners who maintain sort of migratory existence traveling rough the surrounding states following the easons of farm rk. Social differences among then are minimized, not only the outsiders or Anglos but also by the Spanish-Americans enselves.

Thus the Spanish and Mexican land grants for many years. exated to maintain an extremely peaked social pyramid ong the Spaniah-American population of New Mexico. W1th - rapid loss of these grants, however, there resulted an ially rapid decline in the height of the soolal pyramid. are is 11 ttle doubt, however, that certaln restiges of the l class hlerarchy still remain in the minds of the people. 
an example, the old patron-laborer complex, al though dispearing from within the Spanish-American groups, has been talned to some extent. The major difference between the w and old complex is that the patron now 18 usually an 310.72

4. Social Institutions: There is 11ttle doubt that the inlsh and uexioan land grants have boen a major source of Pluence upon the institutional I1fe of the Spanish-American iple of New Mexico. The total extent of this influence in Cerrito 18 beyond the scope of this paper but, In the llowng pages, an attempt is made to Indicate some of the re obvious appects of this influence upon three of the tmary insti tutions of El Cerrito, namely, the family, the weh, and the sehool.

As pointed out earlier, the nature of the land grants 1 conduelve to the development and maintenance of strong ier-vilage and intra-rillage factions. These faotions lally had a family or blood basis, a condition that was ivitable as a result of the reluctance of the faction to iemarny. So strong were the majority of these factions "clang" that the common or pasture lands were divided ween them and to violate the recognized boundarles was

\footnotetext{
72 The tranefer of the patron figure from the spanishrican group to the Anglo group is discusaed in florence Kluckhonn, Los Atarquenos, Cambriage: Harvard University -D. D1anertation), 1940, pp. 13-24.
} 
ilvalent to a trespass of private property under the New gland system of land use. Consequently, the two factions, though l1ving in the same v1liage, had very 11 ttle social stact one with the other.

Within elther one of these groups, however, common tereste and sooial contacts were t maximum. The men *ed together, el ther as laborers for the patron or in laing thelr own herds or flooks whlch grazed together. ler this consolidation of economic enterprises, plus the ldenoy of the group to marry w1thin 1 ts own faction, there reloped in time, all over the Spanish-American area, a tern of highly integrated, extended or consanguine family ups. 73 These larger kinsh1p groups almost deserve to called clans.

The extended or consanguine family 18 characterist10 E Cerrito today. Grandparents and grandehildren are loot as Intimately a part of the family group as are the 'ents and children. It is not unusual for one or two Idren of an immediate family to make thelr home with ndparents or even a brother or s1ater of one of the ents. Any older member of these extended family groups perfectly free to discipline any younger member. Such hority is universally recognized and is seldom if over

73 Ralph Linton, The Study of Man, New York: D. Appletontury Company, 1936, pp. 159-169. 
stioned by elther child or parent. This applies particuif to the female nembers of the family as the males are 't to thetr own Initiative at a relatively early age. Confilets as they exist for the people of gis cexrito almost Invariably between family groups rather than ween individuals. Fhls may be understood only in the ht of the solldarity of the fam1ly groups. Infringement n the rights of the individual necessarily means interence with the righte of the family and all members are mpt in responding to any threat to the individual's wel- Th1s phenomenon has been an important factor in profing wany of the inter-village feuds in the Spanish rican area of New hexico.

Unt1l comparatively recent date all marriages in El r1 to were planned marriages in that perents and grandents of the prospective bride and groom were always aul ted. A primary object of this seems to have been gely a desire on the part of parents and grandparents to n marriages in such a way that holdings of land and liveok might be combined most advantageously. Th1s tendency, erer, has declined markedly with the disappearance of zing lands and the oubsequent loss of the people's I1veok. Today there aeems to be 11 thle interference on the $t$ of parents in marriages so long as the cholce of a wate s not do harm to the reputation of the extended famliy serned. 
In the Spanish and Mexican colonization of the New World the tate and church worked hand in hand. "The formula for the course of action of the crown was exploration, conquest, unity of the churoh, acquisition of wealth, and the inerease of the territorial dominions of the king. The formula for the coclesiastie was--spiritual conquest, inoreased power of the order, salvation of souls, extension of the king's domaln, and frequently, personal temporal blesginge. 74

In the establishment of either spanish or ifexioan colons specifio provision was made for the organization of the churoh in the colony. Each settler was required to attend the church and to support it elther by contributions In money, goods or labor. Fallure on the part of any settler to conform right mean his eviotion from the colony. The ohurch, in each instanoe, meant the Roman Cathol10 Church since no other was tolerated by elther the Spantsh or Mexican governmenta.

The profound influence of the church upon the 1110 of. the people 18 still evident in the Spanish-Amerioan area of New Mexico today. In El Cerrito the influence of religion and the church on these people has diminished but little since early settlement. All are devout Catholies. The

${ }^{74}$ Blackmar, op. c1t., p. 53. 
Influence of the churoh is found in their thinking, in their attitudes and values, and in their day-to-day activities. Servioes are attended regularly and in a humble spirit. Foes are pald promptly and special contributions are made porlodically, if meagerly. Al though 11ttle money may be avallable for food and olothing, way 18 always found to obtein oandies to be burned on special oceasions or to obtain a new costune for a chlld's first communion. The women are especially devout. When special services are held In the church some of the men may remain away, but seldom does a voman absent hersele.

The church 18 by far the wost consplouous and the best kept bullding in the rilage. Willing hands are always avallable should it need repalrs or a new coat of whitewash. Holy days are riglaly observed and Ascension Week recelves special consideration and compliance. Ho work is done on these days because of the general bellef that serlous pun1shment from a divine source would aurely follow. The storles that tell of violations of Holy Days and subsequent retributions are numerous. For example, all in the village are familiar with the experience of a local farmer who, a number of years ago, plowed his corn on a Holy Day. The next day 1 was destroyed by hall. That the punishment was especially meted out to him is sald to be proved by the frot that adjoining flelds of his more devout nelghbors went unharmed. 
As preseribed by the early church algnitaries in $\mathrm{New}$ Mexico the tralning of $\mathrm{El}$ Cerrito ohilaren in the knowledge and practices of the churoh 1s begun at an early age. The chlld's flrat reading is often done from books on the catechlas: Teachers in the school are especially esteemed by the parents if they are willing to help teach the catechism to the children. When a child has arrived at the age of ten he is expocted to know the churoh fitual and to be fam111ar with the teachings and practices of a good Cathol10.

Hel ther the Spanish or Mexican governments encouraged or wade provision for the formal education of coloniste. gducation left to the church, an institution which was opposed to popular education. Schools in the SpanishAnerican area of New Mexloo were virtualiy non-existent before 1890. Those whioh were in existence before 1890 were operated and controlled by the ohurch and the chlldren were taught "religion, reading, riting, and reckoning, four $r^{\prime}$ Instead of the three characteristio of the primitive Bchool of the eastern colonies. Thus, between the formal rites of the church on one side and a life given over to the pleasures of the hour on the other, with enforced laleness on account of the services of the neophytes and preparation for 11fe by way of education, grew up ace of people not able, in education and industrial zeal, to cope 
with the Anglo Baxons." 75

This early disregard for the schools has carried over Into present day El Cerrito I1fe and thinking. There is 11ttle 1ntereat on the part of parenta relative to the local chool. Many parents consider what the chilaren learn in the ohuroh and from the teachings of the catechise a of far more importance than that which they learn in the school. Once the ohild has completed the elght grades offered by the local sohool there 18 no encouragement for the etudents to continue in sohool. Completing the 11 bro ocho (elghth reader) is coneldered to be sufficlent schooling to enable the student to speak and read a 11 ttle Inglish and master any work or skills the student 18 Ikely to need in his Ilfe's work.

Thus, it 18 obvious that the Spanish and Mexican land grants have affected the institutional life of the SpanishAmerleans as well ag their social prooesses. Naturally faotors other than the land grants have also influenced the present das school, church and family systems found in EI Cerrito and other Spanish-American villages. However, it 18 also maintalned that the influence of the land grant on the 1nstitutional iffe of these people is of such significance that it cannot be alsregarded in any attempt to

$$
{ }^{76} \text { Ib1d., pp. 267-268. }
$$


understand the bocial Ifre of these people today. In fact the nature of the land syaten, largely molded by the Spanish land grante, has in turn becone one of the primary determinants of present-day institutional patterns.

5. Higration: Seasonal migration, or the movement of the people fros one place and job to another, is a phenomenon that has only recently come to characterize the Spanish Amerloan area of New Mexico. The origlnal Spanish and Mexioen land grants always provided ample land resources to enable the settlers to remain in one place, settled in a viliage, tilling their nearby Irrigated holding and grazing their sheep and oattle on outlying lands. W1th the loss of. these lands, however, the sedentary pattern of 11 fe necessarily underwent arastic changes. The lands remaining in the hands of the people were Inadequate to furnish more than a small portion of the things necessary to satisfy people's needs. There began an era of moving about searching for exployment during parts of each year. Thls became perlodic since the fanilies always came back to their rillages once the work season was over.

Th1s pattern of seasonal migration in search of employ- . ment may have been ador ted by the people of al cerrito somewhat earlier than in other parts of the Span1sh-American area. When the Santa Fe Ra1lroad began its I1ne across the area around 1875 some of the people of Il Cerrito, $11 \mathrm{VIng}$ 
rery near the main 11ne, began to work as day laborers for the rallroad. Others furnished ties which could be cut from the timber on thelr comon grant land. This work proved to be falrly steady for several years and the pay was considerably above that a worker could earn herding sheep. By the time the road wa IIn1shed, around 1890, the people returned to the land. However, they remalned there only about flfteen years, because, as has been Indicated, the decision of the Court of Private Land Claims turned thelr common lands into public domain.

with the loss of title and use of thelr comnon lands, which becane effective around 1916, there was no al ternative but for the men again to seek work outside the viliage. Their experience in herding sheep ensbled them to secure work for large liveatook concerns not only in other parts of New Kexico but in surrounding states as well. Other sources of employment were in the beet fields of Colorado, Wyowing, and Utah; some of the men were able to securo somewhat better pay in the employ of mine and smelter companies in these same tatos.

once begun, this type of work continued unt1l the de-' pression of the $30^{\prime} \mathrm{s}$ made $1 \mathrm{t}$ extremely difficult to secure work anywhere. Each year the men would leave the village en wasso to be gone for periods 2.8 long a $81 x$ or nine monthe without coming home. As rule the women and children 
Fould be left at home where they could t1ll the 1rrigated holdings of the families and oare for the I1vestock. With the money thus earned in outalde exployment plus the food produced at home a family could live at about the same level as in the past.

One of the most interesting observations on the exten- . 617e seasonal migrations of the Spanish-American people of Hew Hexico is the tendency of the small, irrigated holdings in the villages to puIl the migrants back to thoir homes once the season of outside work is completed. Farliles in E1 Cerrito frequentiy comment on opportunities they have had to remain away from the village permanently but only a few have ever taken advantage of such opportunities. This "pull" of the land has created something of a paradoxical o1 tuation in the village of EI Cerrito, 28 well 28 in the Spanish-American area as a whole--an extremely moblle adult male population offoet by an intensively stable or sedentary family population.

6. Soclal Mobility: During the Spanish occupation of . Hew Mexico social stratifieation of the population was at 1 ts peak. Strains of royal blood, speclal honors conferred upon selected officials created social distances between familles and other groups that were readily apparent to all. soolal distinetions prevented the man of Castilian blood from ssoclating soclally with the lowly peon or the government sponsored colonist. These social distances were 
universally recognized and seldom violated. To a considerable extent these differences in olasg also were of a cabte aature. There was no channel or ladaer by which the peon, could olinb into the ranks of the privileged group. Once etabliahed the ranks tended to prevall generation after generation.

Later, with the rise of the patron class among the Spaniah-Amerlcant, however, the channels of clroulation between the layers of the soolal pyratid became more open and the caste element became of 1 ess Importance. A man with some ingenulty and businese acumen might rise within a few yeare from the laboring elas to the exsited status of a patron. Beonomic position came to be a dominant factor in sosial status. W1 th the development of this class and the aceomanying decline of the nobllity the soolal pyranid of the Spanish-Arertean population sloply began to flatten out. Phis rlattening procese was accelerated with the pasing of tine by the tendency of the residents of a village to intermarry. Thls ohange was conconitant with the rlee of the petron class, wine there was less reluctance on the part of the petron and his fanily members to marry outside their econowic and social olass than had been true for the older nob111 ty.

W1 th the coming of the Anglos into New Mexico the soolal pyramid of the Spanish-Americans underwent another radieal change. The Anglo cared 11ttle for the existing 
class hierarchy and social distinctions. To him a person that opoke Spanish was a "Mexican," and it made no difference whether he was a patron or a sheep herder. Wuch of the ex18ting 111 feeling between the two group dates from the time when the ineoming Anglo dubbed the Spanish-American as "Mexican" and was oalled "gringo galado" in return.

In the history of II Cerrito may be traced the change In soolal moblilty that has taken place over the entire Spanioh-Amerioan area. Older residents of El Cerrito remember the time when the patrones of the village oceupled a position of extrene power and preatige. But, with the loss of the resources of the patrones went the power and prestige associated with them. In present day EI cexrito the social pyramia is about as nat as it could be. Xinship t1es between almost all the fam1lies plus com on menbership In all the social grouplngs have removed nost of the basis for group and family distinction. Only the fow families which are not related to the main fanily grouping of $\mathrm{El}$ Cerrito wight be considered as at a slightly lower social level and there is no restriction to their marrying into the mais family group.

The channels of social mob1lity outside the village of. El Cerrito are seldom uaed. As pointed out earlier, a certain anount of college work would make it possible for a resident of El Cerrito to do profeselonal work or service 
outalde the v1llage but this has rarely happened. Poor local schools and the poverty of the people make it extremely diffioult for a young person to secure the substantial amount of education which would be necessary in order for him to move up the social pyramid in the outside world. Even should this be accomplished ho must assoclate almost entirely with his own people sines the associations between Anglos and the people of El Cerrito, as well as the Spanish-American people as a whole, are alwaye at a minimum.

Thus, the people of EI Cerrito, and the majortty of Spanioh-Americans in all New Mexlco, 11terally have become enclosed, first, by a wide expanse of land owned and fenced by outside interest and, seoondly, by an al1en culture whose carriers have al ways considered themselves superior to the "Mexicans." Phese two factors have driven the Spaniah-American people back into thelr last stronghold-their small village with ita individually owned, small, irrigated holdings. Here, for the past few decades, they have been able to maintain themselves in a fashion discussed in previous pages. How much longer they w111 be able to hold out, unlese relleved in some manner from the outside, 18 a problem confronting not only the Spanish-American people themselves, but every agency interested in the welfare of the area. 
CHAPTER VI

SUMAARY AND CONCLUSIONS

In th1s study an attomat bas been made to deternine the nature and importance of the Spanish and Mexican land grants as a factor influenoling the social organization and processes of the Bpanish-American settlements in northern Hew Hexico. A great deal has been written on the economic 1mportance of the land grants in the Southwest but 11ttlo attention has ever been given to the soclal significance of these grante to the people living on thea.

Both the Spanish and Iexican authorities were Ilberal in the alstribution of their weatern lands but the syetem of distribution used placed many restrictions upon the settlers ocoupying the land. Most of the land distributed was allocated for the conmon usages and not given in fee simple to Individuals. To facilitate this comon use epeelal provibions were always made for 1 ts oomon maintmance and improvenent. Since the church and state worked hand in hand In all colonization, possegsion and use of the land grants by the colonists were dependent upon complianoe with re11 glove requirements and support of the church. In addition to these epeciflc regulations lald down by the authorities, 
the nature of the grantg themselves was an Important fector In ahaping the social I1fe of the poople in the SpanishAmerican area. The extenatveness of the grants, their comen poseession and use, inderiniteness of thetr surveys, boundaries, and tities have oombined to produce an economic and social altuation in the Spanish-American area that is entirely different from what might be thought of as representative, American rural ilfe.

In order to determine some of the soolal influences of th1s land eystem and 1 ts cubsequent changes on the people arfeeted, the villege of El Cerrito, New Mexico, wa choven for intensive study and andysis. In ohoosing the village four main oriteria were set up as the basts for making the selection. They were: (1) it must be entirely Spanish apeaking, (2) It must be situated on original Spanish or Mexican land grant, (3) 1 must be a definite part of the Iarger Spanish-American area, (4) 1 t must bo sufficiently 180lated from main highways or larger towns that 1t woula not have been influenoed by them unduly. It is belleved that $\mathrm{q}$ Cerrito meets these eriteria of selection satisfretorlly.

After selecting El Cerrito for Intensive study the witer epent approximately seven months in the viliage, gathering a wide range of information and materials on the land situation and the people. An attempt was made to 
partlelpate in the IIfe of the village as far as possible. It is belleved thte was accomplished as nearly as it could possibly be done by an outsider.

The history of the village proved to be an abstract of the Spanish-Amerioan area a whole. It was part of a large land grant given to the people by the orown of Spain in 1794. Here the people had been 11ving since little past 1800, pasturing thelr herds and flooks on the oomon or grazing lande and farming the omall, irrigable tracts of land in the vel1ey. Titie to the common land was held by a speolal Board of Frustees elected by the people. Fanilies held their own t1tles to residentlal lots and plots of 1 rrigable land. Wh the coming of the American Iand bystem into the area, however, the situation underwent rapid change. Common Iands whioh bad been in use by the people for almost a century were tamed into public domaln. Fam1lies were left with only thelr 1rrigable holdings whoh were inadequate for more than a howe s1te and a good alzed garden.

With this information of cerrito land and people in mind an attempt was made to discover some of the factors in the nature and history of the land grants that hed been instruental in bringing the situation in EI Cerrito, and incidentaliy the entire Spanish-American area, about. Some of the major finding and conolusions may be sunmarized as Pollows: 
1. Bettlement Pattern: One of the most distinguishing features of the Spantah-Amertean area of New Mextco is the tendeney of the rural people to i1ve in a v1llage or olustered type of settlement. This pattern of settlenent was made mandatory by both the Spaniah and Mexican colonization authorities in the grants of land which they gave. Living -losely together was oonducive to operating the small, indifidualiy owned, 1rrigable tracts of land and also fastered oooperation in ut111zing the common or pasture lands at some distance from the village. Subsequent los af the oormon or pasture land has had 11ttle effoot on the old pattern of settlement. Opportunt ties for the fanilies to move out of. the village onto patented land have been minimized by the tendency of large tracts of land to remain intact in shifts in ownership. In adition, the owners of Irrigated land have been reluctant to leave wi thout assurance of something as peranent elsowhere. Thus throughout wuch of Hew Mexioo today, the village form of settienent still prevaila, a heritage from the Spanigh gystem of settlenent and granting or land.

2. Survers, Titles, and Land D1vigion: A laok of acourate surveys, ambiguous and imperfect t1ties, a gyster of land division based on metes and bounds, all chareoterlstic of both 3pan1sh and Mexican land aystems, today are a conotant plague to the people of New Mexico. Before the arrival 
of the Americans in Nem Mexico these phenomena had occasioned numerous confliets and dipputes, some having persisted in the Spaniab-Ameriean area unt1I today. After the arrivel of the Anglos, Wth new syster of surveys, titles and land diFision, the affioult problen arose of imposing a new land system orer the old one. The reault has been endiless confusion, and in the end an enorsons lose of land by individuale, families, and entire villages. In El Cerrito, as well as In the entire Spanish-American area, the people have been able to retain $11 t$ the wore then the irrigated traetg to phich they could prove individual ownership. The lands formerly held in comon generally have passed into the private ownership of outside people and corporations.

3. Land Tenure: The raot that both Spanieh and Nexican. land grants made epecific provision for each colonist to own some Iand acoounte, In Iarge part, for the high peroentage of land ownership ang the Spanish-American population today. These grants are also responsible for the fact that most of these holdinge are extremely small, much too limited In size to produce more than a part of the food needs of the people concerned.

4. S1ze of Holdinge: The extensiveness of the land grants in northern New Hexico has been a atrong factor in preventing the rise of a large numiber of middle sized holdIngs in the area. These grants were originaliy conduelve to 
the development of a fer large livestook operatione which comnated the grazing lands and emplojed the bulk of the renalning families ab laborers. This pattern has changed but 11 ttle since the loss of the grant lands to the spanishAnerioan people. Hany of the grants allowed by the united Stated courts vere bought from the original grantees for taxes; others that were converted to the public domain coon oame into the hands of outside interests, el ther through consolidation of purchases or through leaser from the state. Small, Irrigated, and individually omed tracts of land, however, have rewained in the possession of a large number of owners. Thus, Bince early Spanish oceupation of New Hexice, slze of Iand holdinge in northern New Mexico has been characterized by one of two extremes, large holding a for the we of fer families and numerous small holdings for the use of the renainder.

5. Competition, Conflict and Gooperation: The land grants of Mew Uexico have been the source of both conflict and cooperation among the Spanish-Americans. Inter-village and intra-village connicto arose through erequent disputes over rights Involving use of the land. Prespass was made eacy by the lack of fences or even knowledge of where the real grant boundarles were. Once begun sueh oonflicta frequently dereloped into open feuds which lasted long after the source of conflict had been removed. On the other hand, 
cooperation between the "In-groups" of the area was pronounced. All work of a comunt ty nature was done through contributions of labor and usually with a minimum of friom tion. Vestiges of this early and extensive cooperation atin remain in el cerrito and the thing is true for the majemty of the other villages within the entire SpaniahAnerioan area.

6. Aleommodation, Assimilation, and Aoculturation: The nature of the Spanigh and Mexican land grants, in their wide expanse of termtory, coneentrating the settlers in olusters and exeluding everyone else, has obviously retarded the functioning of these soolal processes enong the spanishAmerican population of New Mexico. Situated in widely diapersed and inaccesalble spots of the state, miles from any sort of modern transpontation, the people of the spanishAnerican area have 11 teraliy boen out of contact with the rest of the world. Some of the mechanleal evidences of this 1solntion today may be found in the people's poor mastery of the Eaglioh language and their lack of regard for or interest In popular education. Briefly, this 1solation from other. peoples has resulted in the maintenance of old Spanish oulture in the area to such an extent that an Andulusian of 18th century Spain would probably feel much at home in a Nillage such El Cerrito today.

7. Soclal Stratification: During the early Spanish 
oocupation of New Mexico the social pyramid anong the people was highly peaked. At the top of the pyramid whs a amall group of familles whtoh onjoy id the special fevor of the spanish orom. At the botton of the pyramid were the peons and fust above then the government sponsored colon1sts. By 1821, the beginning of the rexioan domination of New Mexico, the noblitty had all but diseppeared and their place had been taken by a new group of patrones who monopollzed the 11vestook industry of the atate. This group persigted until after the American eceupation of the territory in 1846 and have not ent1rely aisappeared today.

With the arrivel of the Anglo, howerer, the social pyranld of the spanish-Amerlean group raplaly began to flatten out. Part of this was due to the $10 \mathrm{se}$ of resources by the patrones and part to the fallure of the Anglo to reoogalze the existing elass hierarohy. Ar a result of these factore, plus a constant tendenog of the patron fanllies to mary outside their own group, elass distinctions between the Spanish-Americans were reduoed to the extent that the status of the petron was 21 ttle higher than that of the Iaborer who once had worked for htm. Today thare are fow class or fanily distinetions in El Cerrito and, with few exceptlons, the same thing could be oald of all villages in the ent1re Spaniah-American area of the state.

8. Soc1al Institutions: The church and the state went 
hand in hand in the conquest of New Hexico. Each was dependent upon the other and the strength of the combination preralled over all resistane frors the indigenous people as well as the oolonists who oame in to oocupy the conquered torritory.

The division of laber between the two powers gav the churoh the responsibility for the moral and intelleetual upbringing of the colonists. AB a result popular eduestion was negleoted al though the teachings of the church were well provlded for throughout the Spanish and Hexican territory of ocoupation. Fach land grant given to settlers made speoiric. provision for ineorporating the poople into the church although no proviaion was ever made for the bullding or maintenance of sohools. Evideno of this emphasis is obvious in El Cerrito today. Each fam1ly attends churoh services regularly and supporti the church financialiy as far as its budget will allow while little interest is ovidenced in the arpport and teachings of the school.

The influence of the land grant on the Spanish-American fanily has been profound. As the reault of common interests In grant lands and a tendency on the part of spatially proximate familles to intermarry there has developed in the Spanish-American area a type of extended or consanguine family. In these familles are 1noluded grandparents, grandchlldren and brothers and sisters who are almost as intinate 
a part of the fanily as are the parente and children. In El Cermito, and many other villages of the Spanioh-American area, one of these intimate blood groups includes the majority of all the familios in the settlement.

9. Migration: When the comon lands of the Bpanish and Mexioan land grants were emple in extent for the denands of the occupants there was Iittle need or opportunity for the people to wove about from one place to another. Wi th the loss of these lands, however, the men of the spanish-American " villages were forced to leave thelr homes for parts of each year to seek employment. Most of this work has been supplied by the beet fields and Iivestock industries of the surrounding states, enterprises whioh require supplentary labor during peak seasons. During the spring and fall seasons of each year the men of the Spanieh-American Villages leave their howes returning after the seasonal work is completed. Heanmile the women and chlldren rewain at home tilling the irrigated lands of the village which supply a limited anount of food to supplenent what can be bought with the wen's cash earninge. This pattern of migration is highly unifora throughout the entire Spaniah-American area.

10. Soc1al Mob1lity: The New Mexico land grants, under. the Spanish and Mexioan regimes, were conducive to the maintenance of considerable social distance between different family and other groups among the Spanish-American population. 
With the rise of the patron olass, however, a olase based on property rather then ancestry, the channelo for soclal mobllity beoame more open. attitude of the Anglo toward the span1sh-Amerioan olass hierarchy and the tendency of the patron class to maxry outside their own group both acted to break dow the barriers of elass distinetion.

roday In El cerrito, as well a in the Spanish-American area as a whole, clase distinetions are at a minimur. A1though there remain a few Spanish-Ameriean families in the patron clase by and large there are no major class distinetions. Social distinctions are now much more on the basis of auch factors as age and polltical acumen than upon property holding or olalms to royal blood or favor. Marmages in the ares have come to be based much more on Individual merit than upon class or family background. 
APPENDIX A

PHOTOCRAPHS 

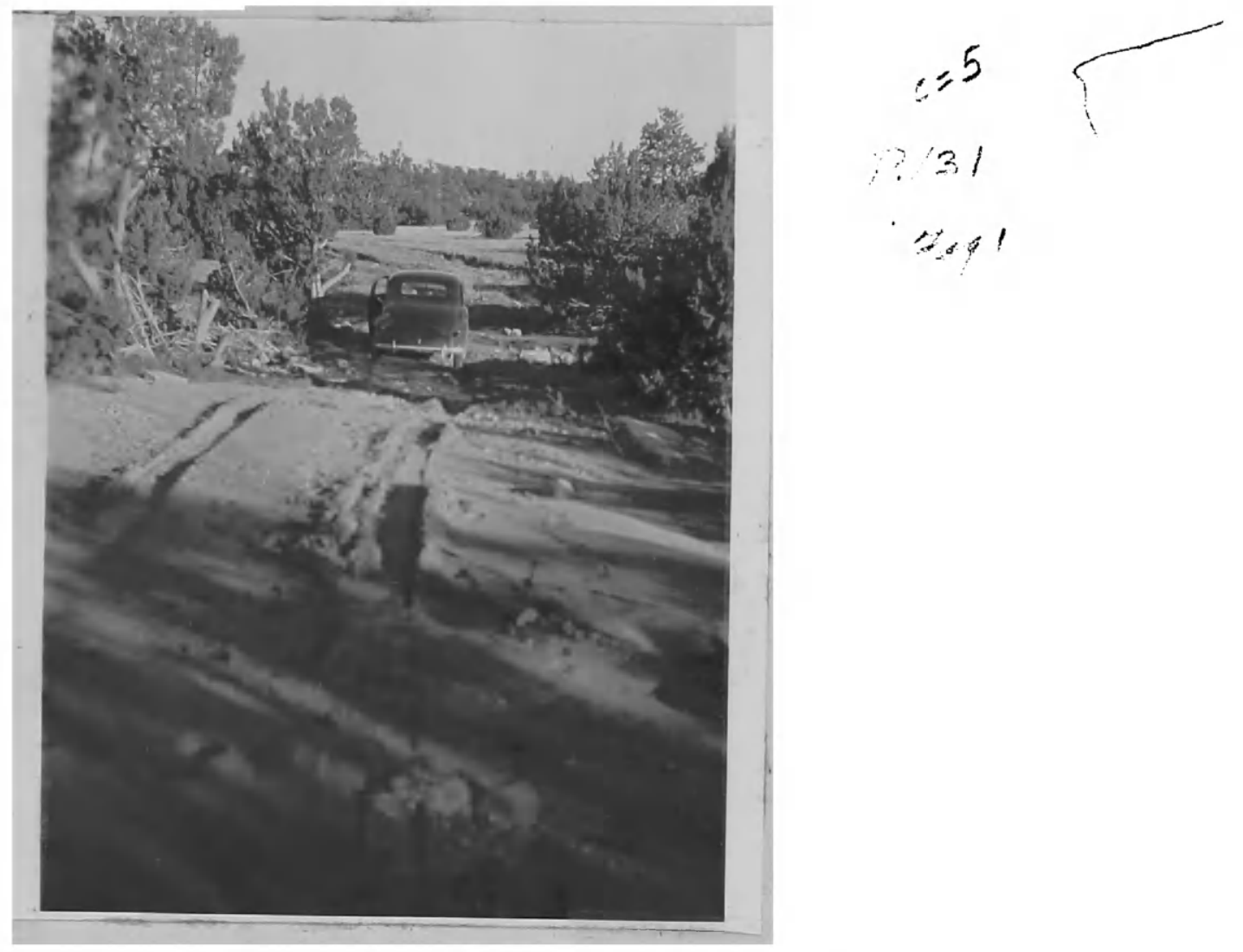

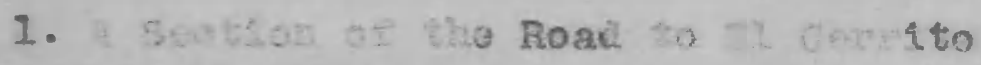
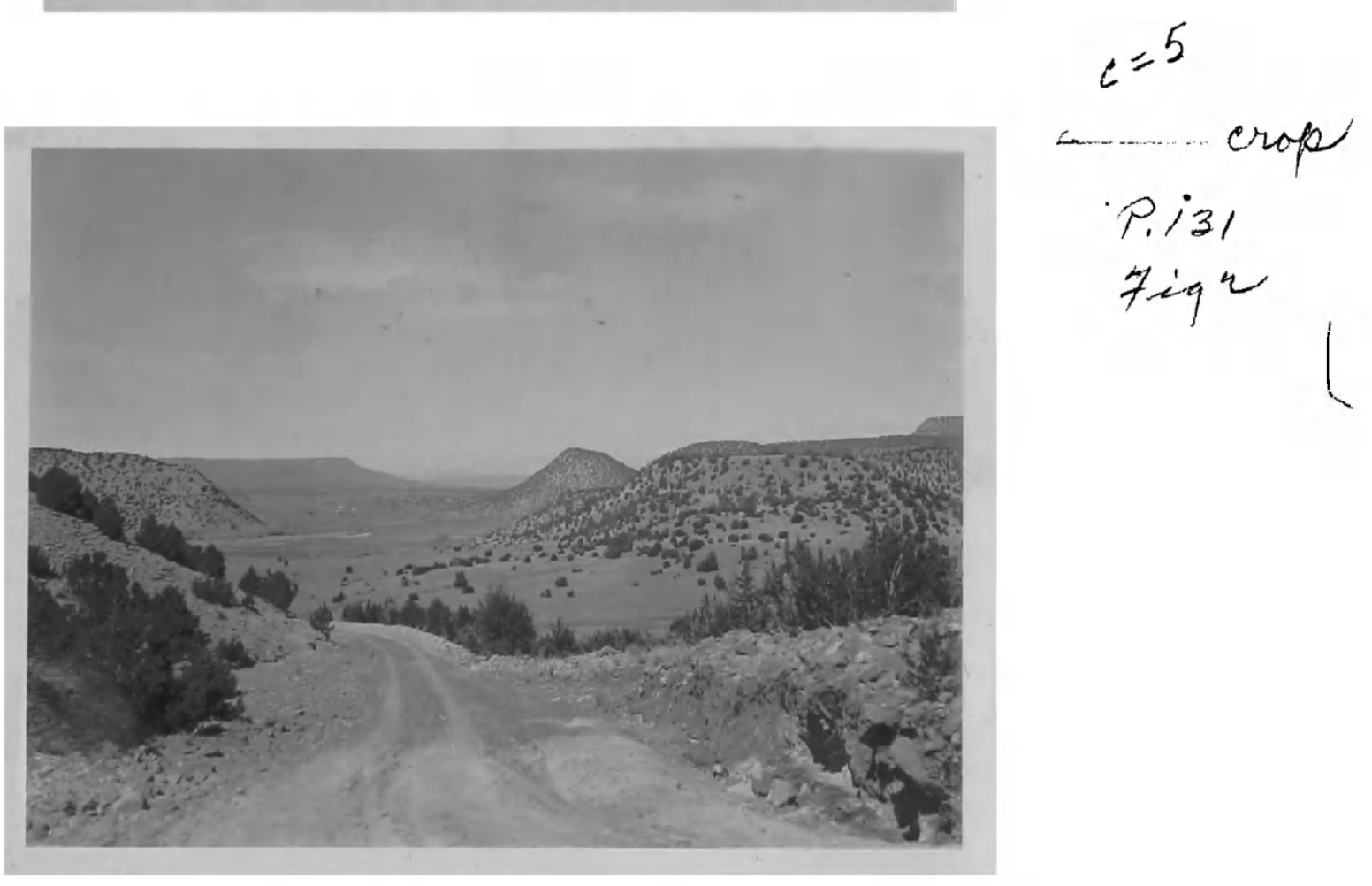

2. Beylunting the Degeent. into the Valley 


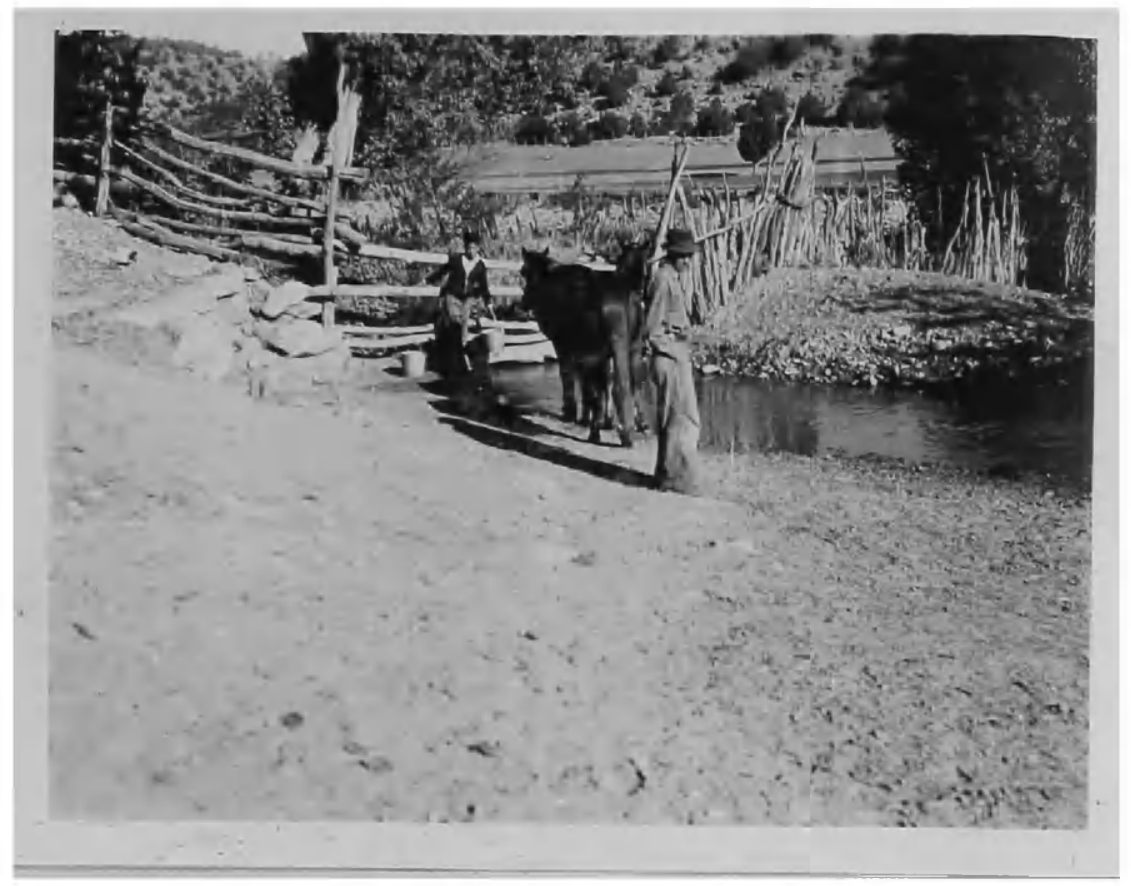

$$
\begin{aligned}
& c=1 \\
& P: 33
\end{aligned}
$$

6. The Hadre Acequid Where Fanilles and LIVestock thet Water

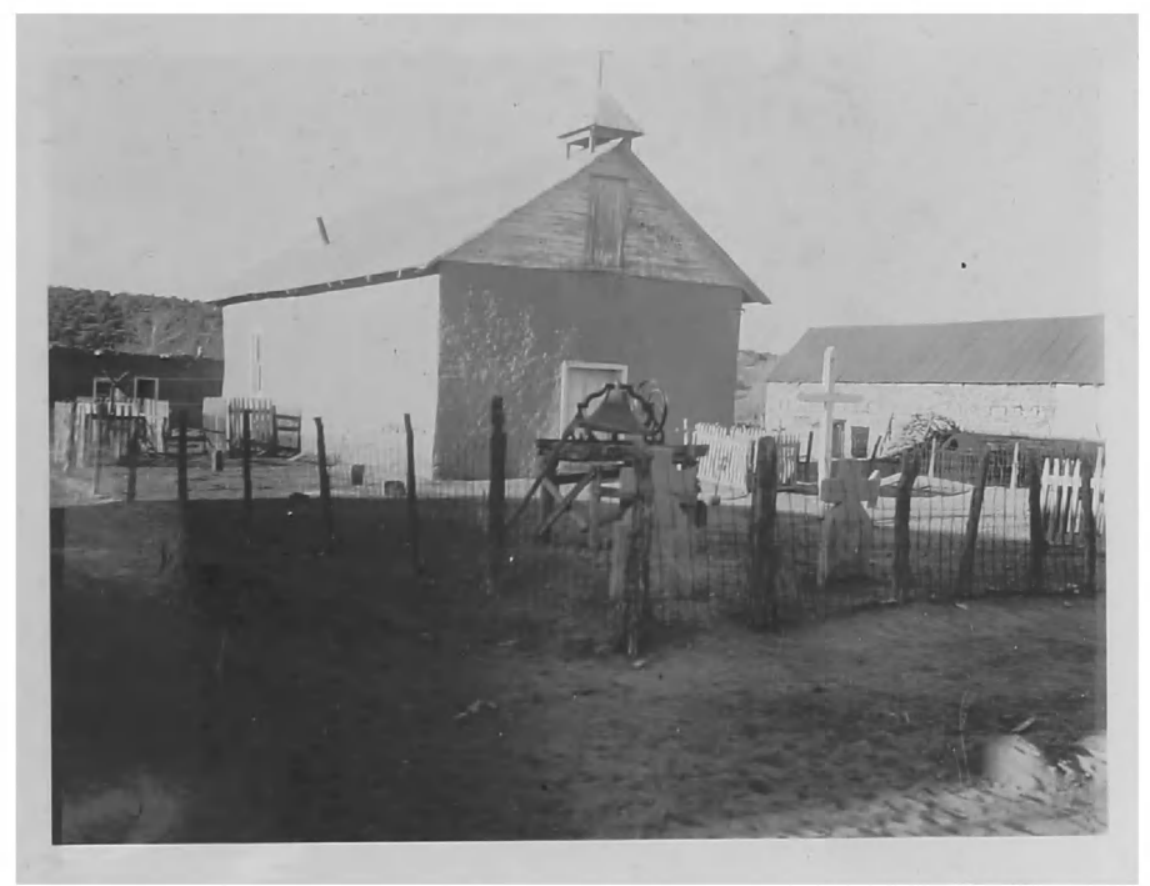

$$
\begin{aligned}
& c=1 \\
& P, 33
\end{aligned}
$$

6. The Chumeh is by Fax the Dest Kept Bullding in the Village 


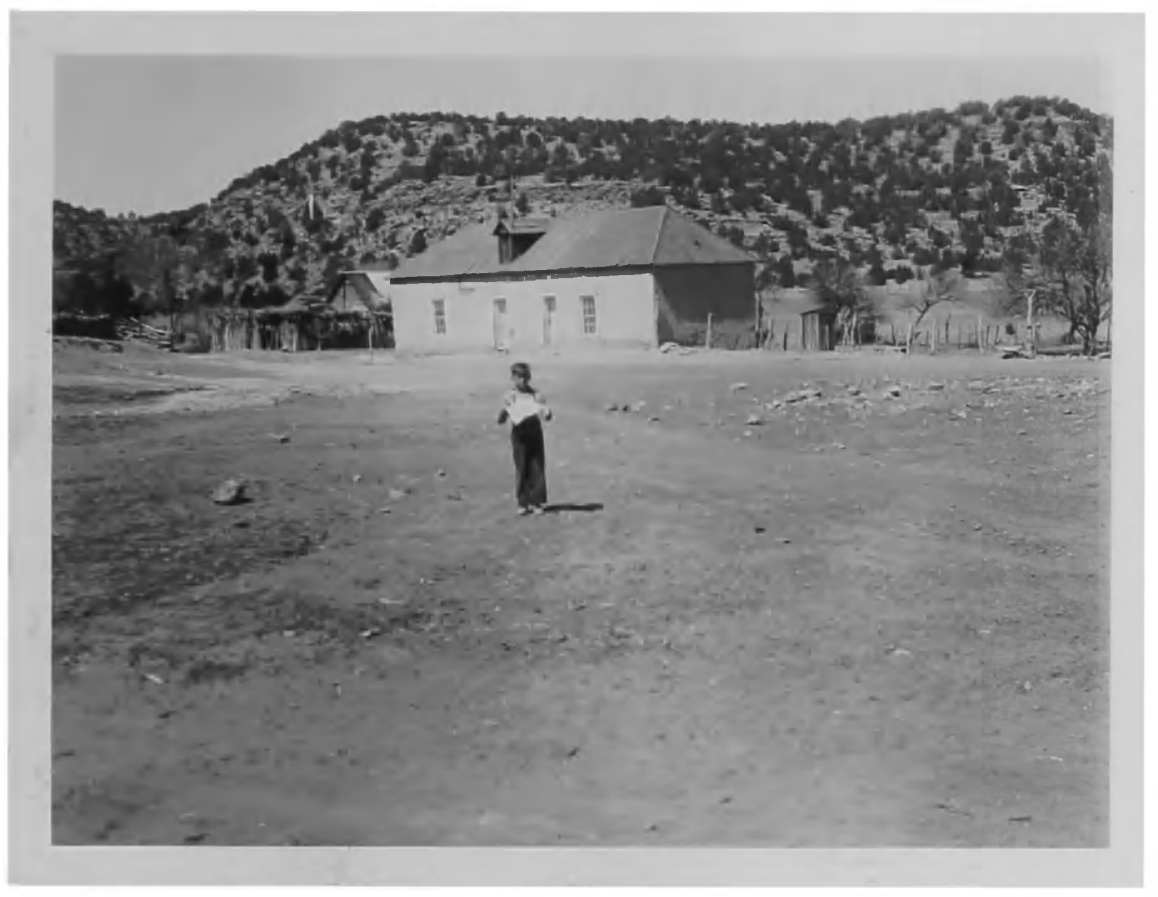

$$
r=1 \text { Page } 134
$$
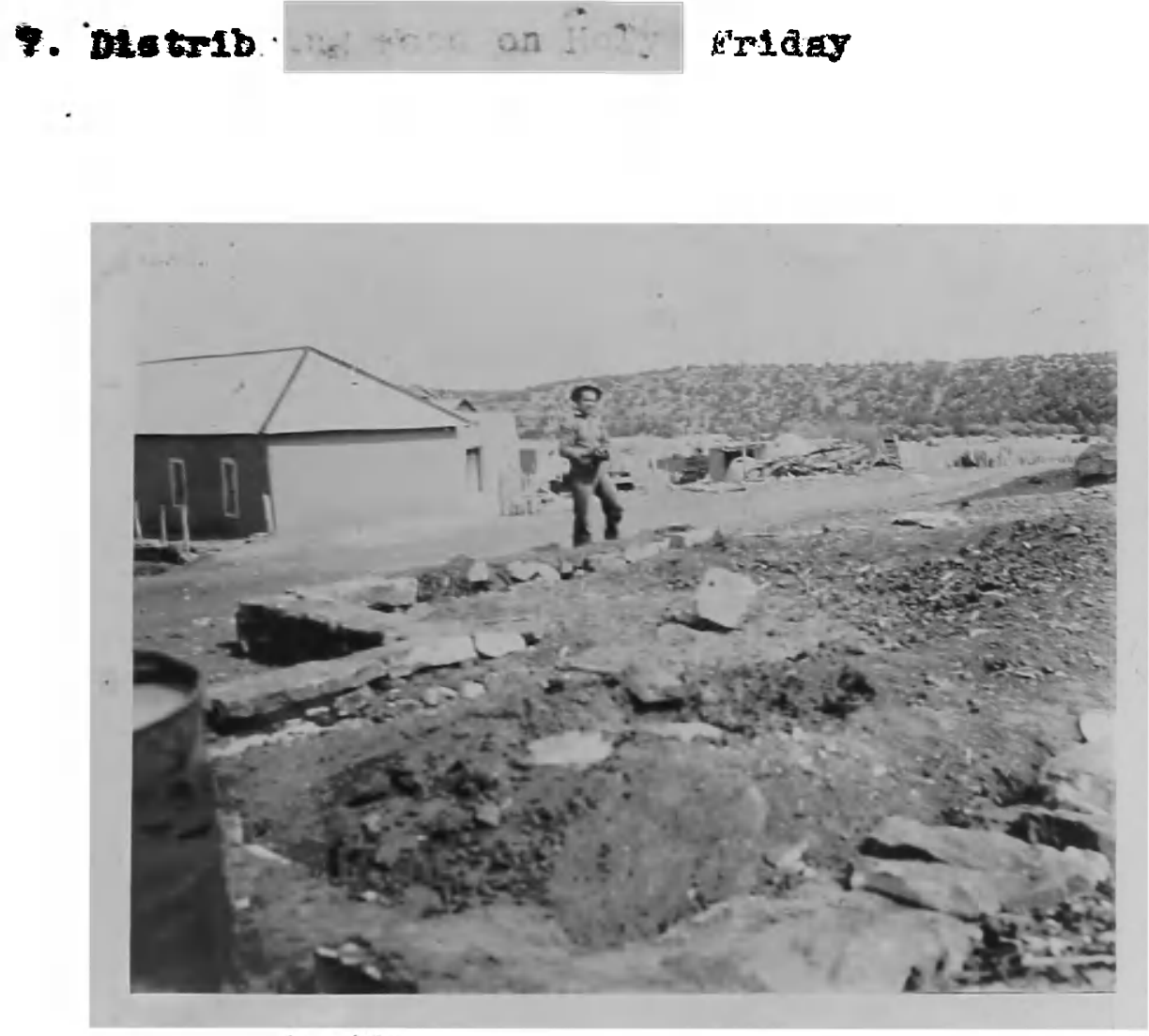

$$
c=1
$$



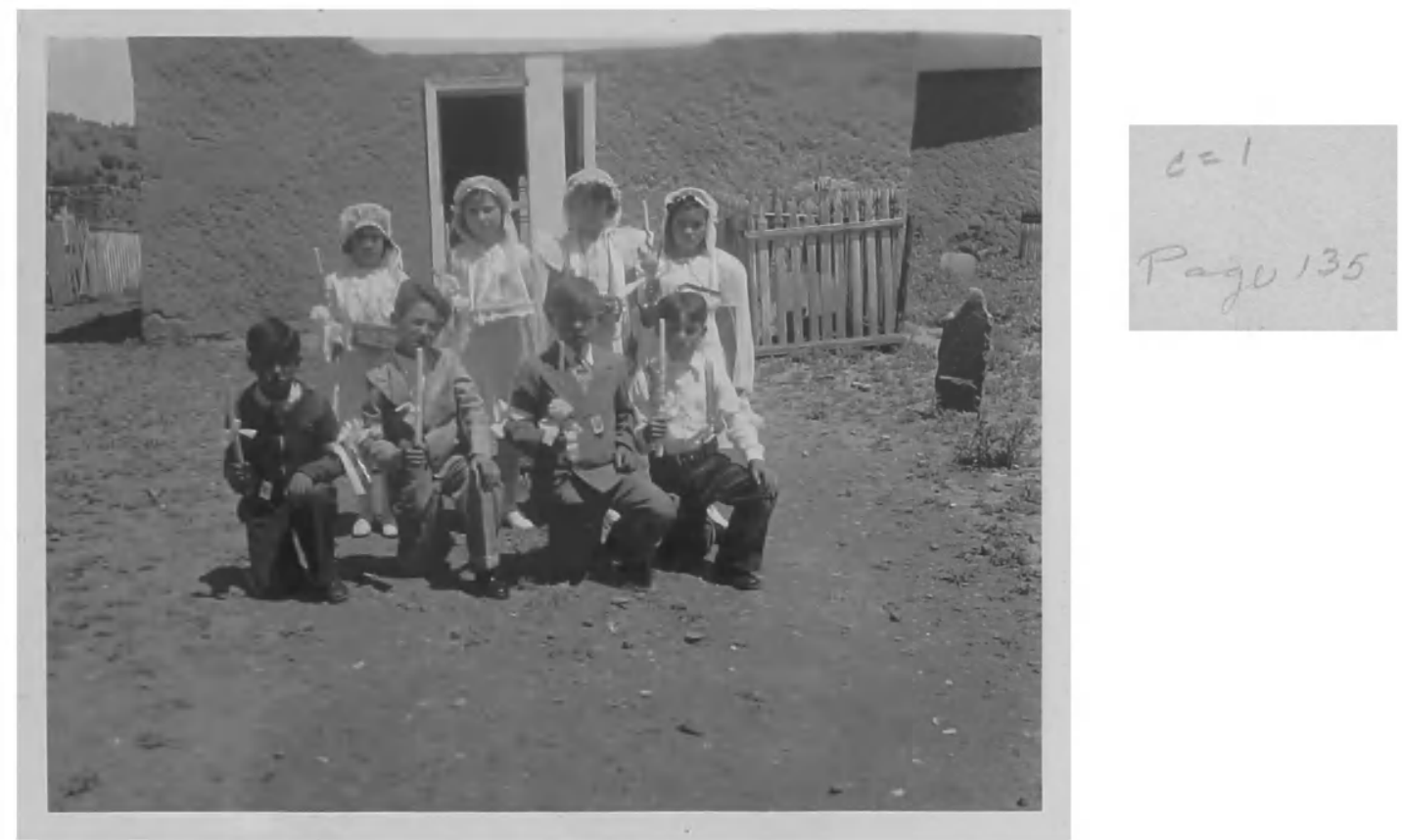

9. This is a Day "We Alway Remenar."

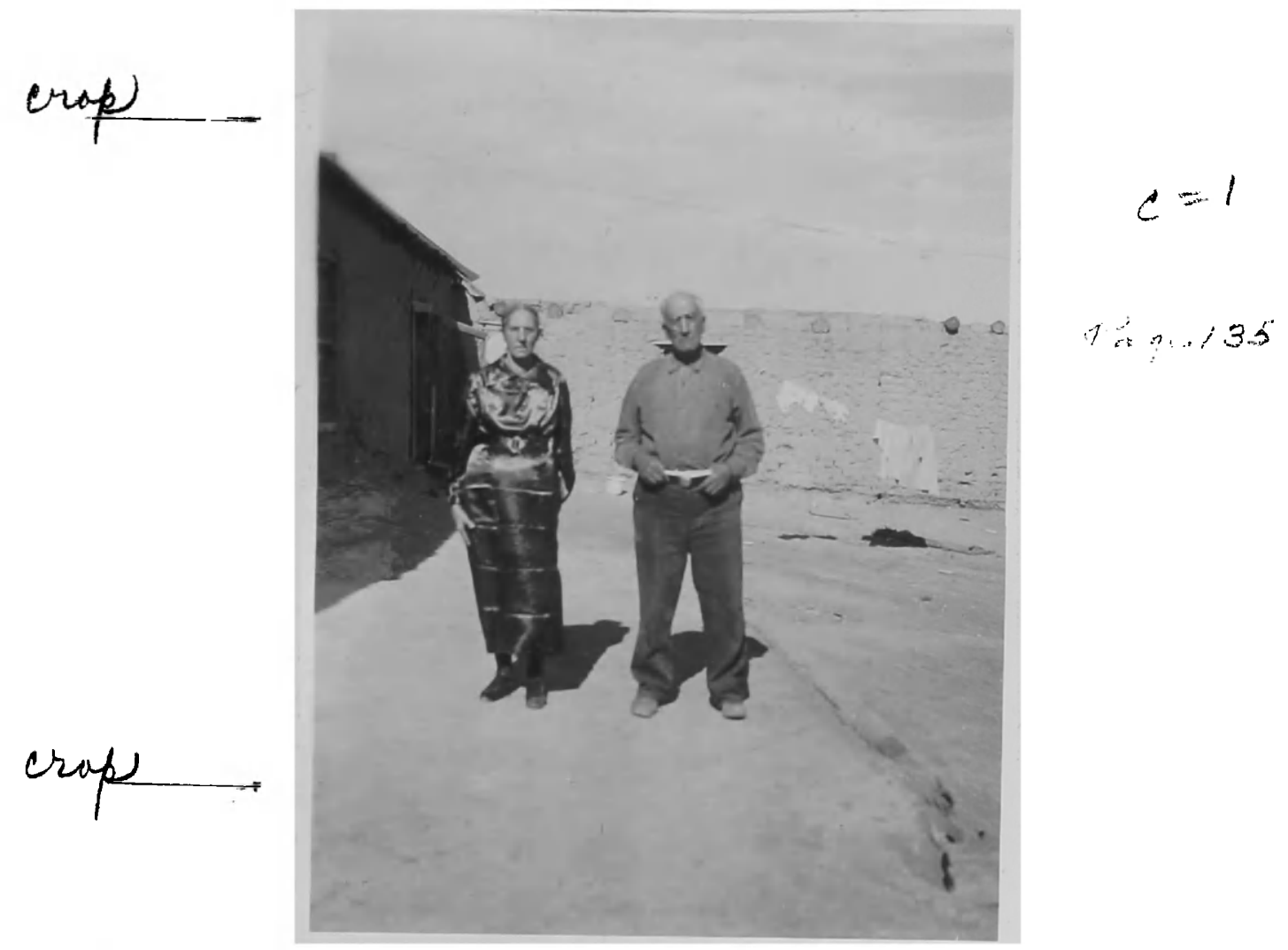

10. The Viliage orater and Hia wifo 


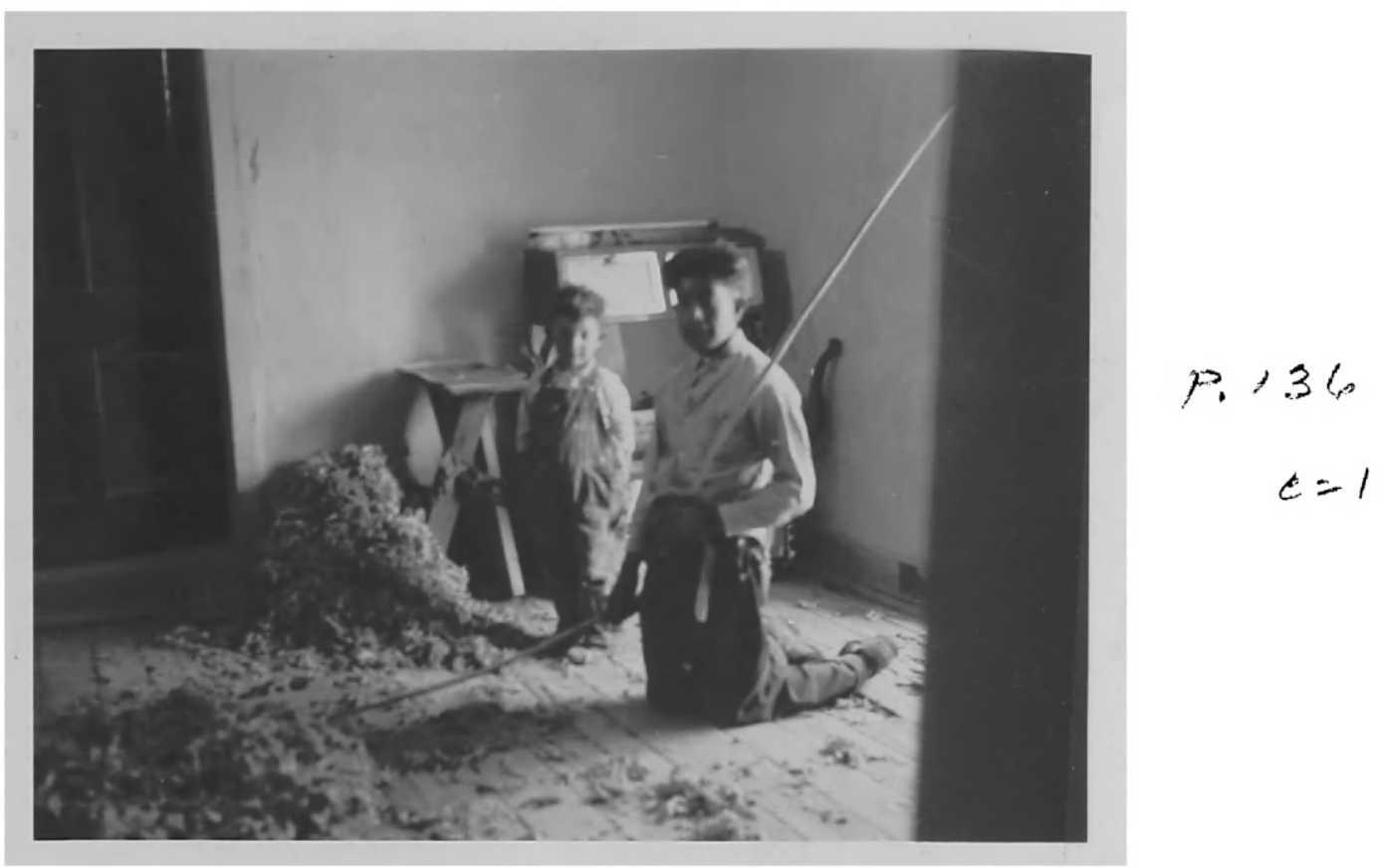

12. Opring weaning. Pagtats the Fool from a Mattroas

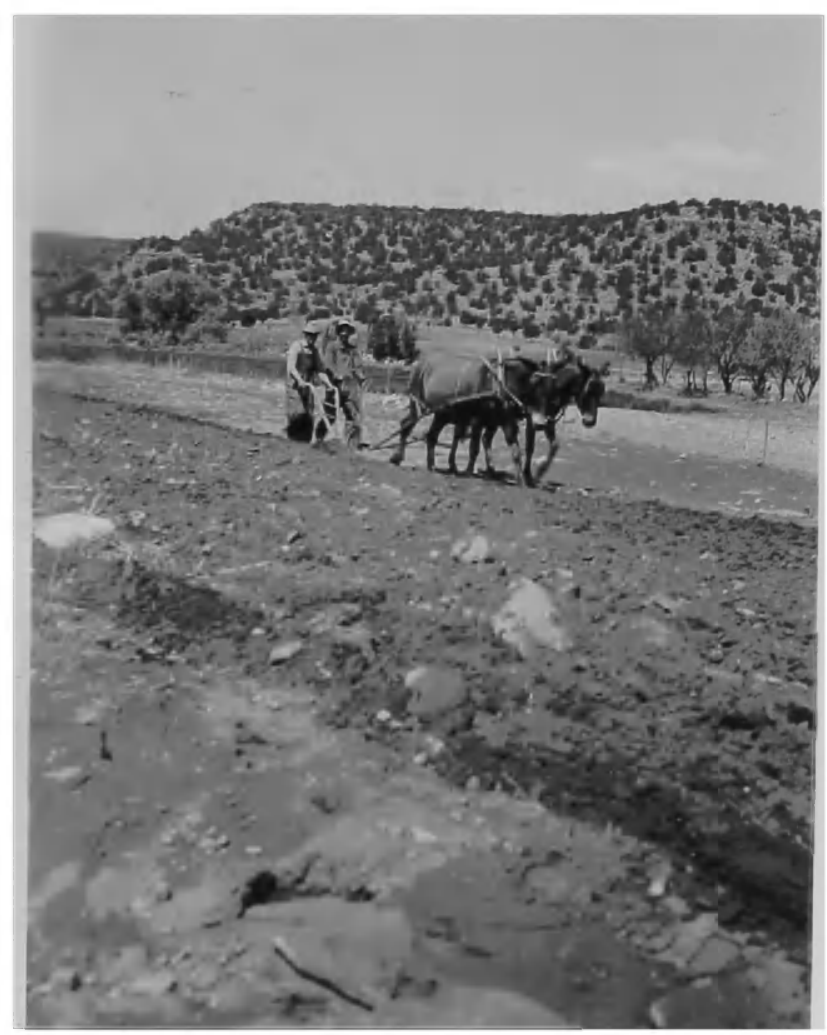

$$
\begin{gathered}
p 6 \\
c-1
\end{gathered}
$$

18. Two Men, Two Mues, 10-1nch Plow 
294

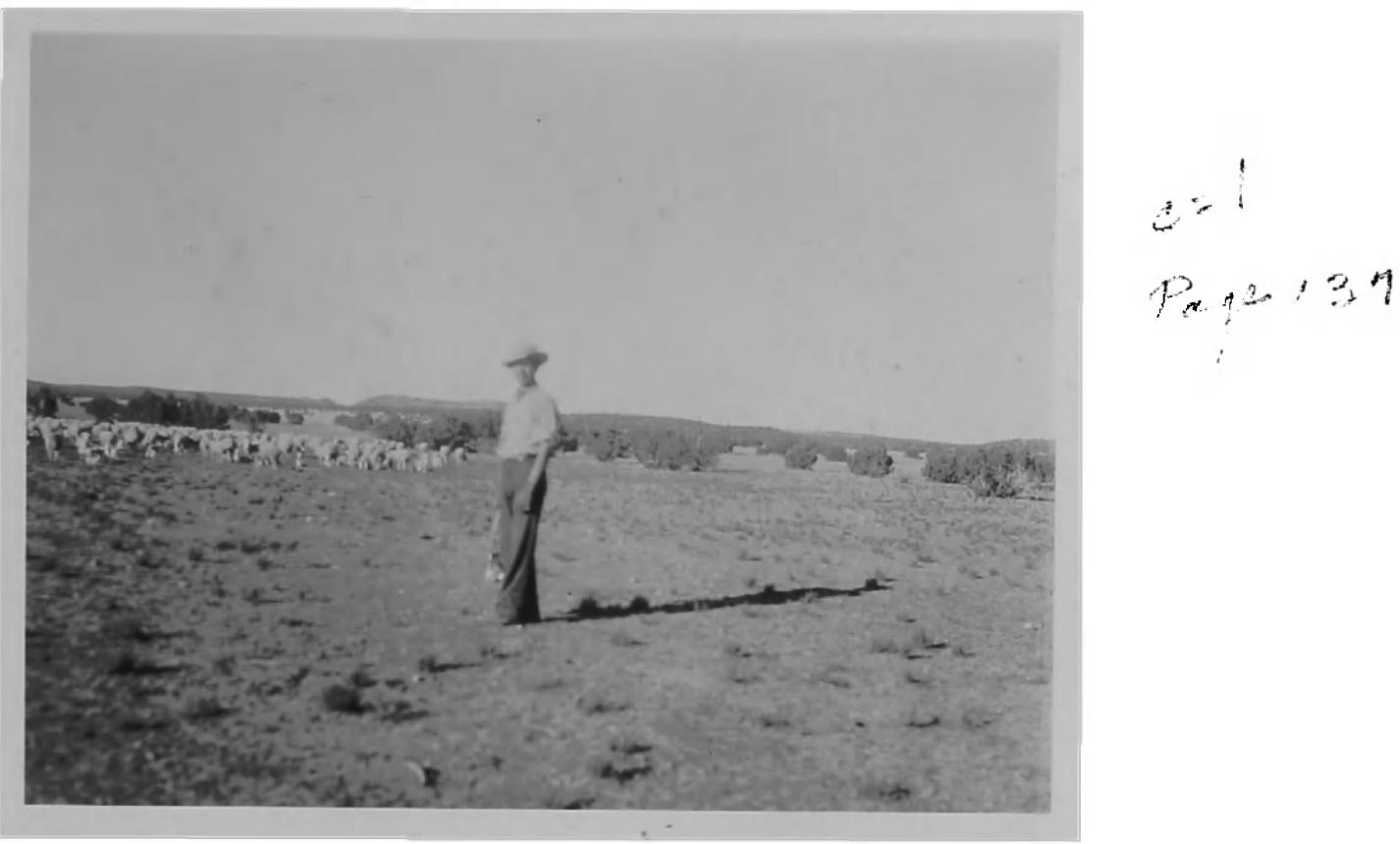

13. These People Kyo the Reputation $\cdots$ sheepherdere 4 ... the 3 tate

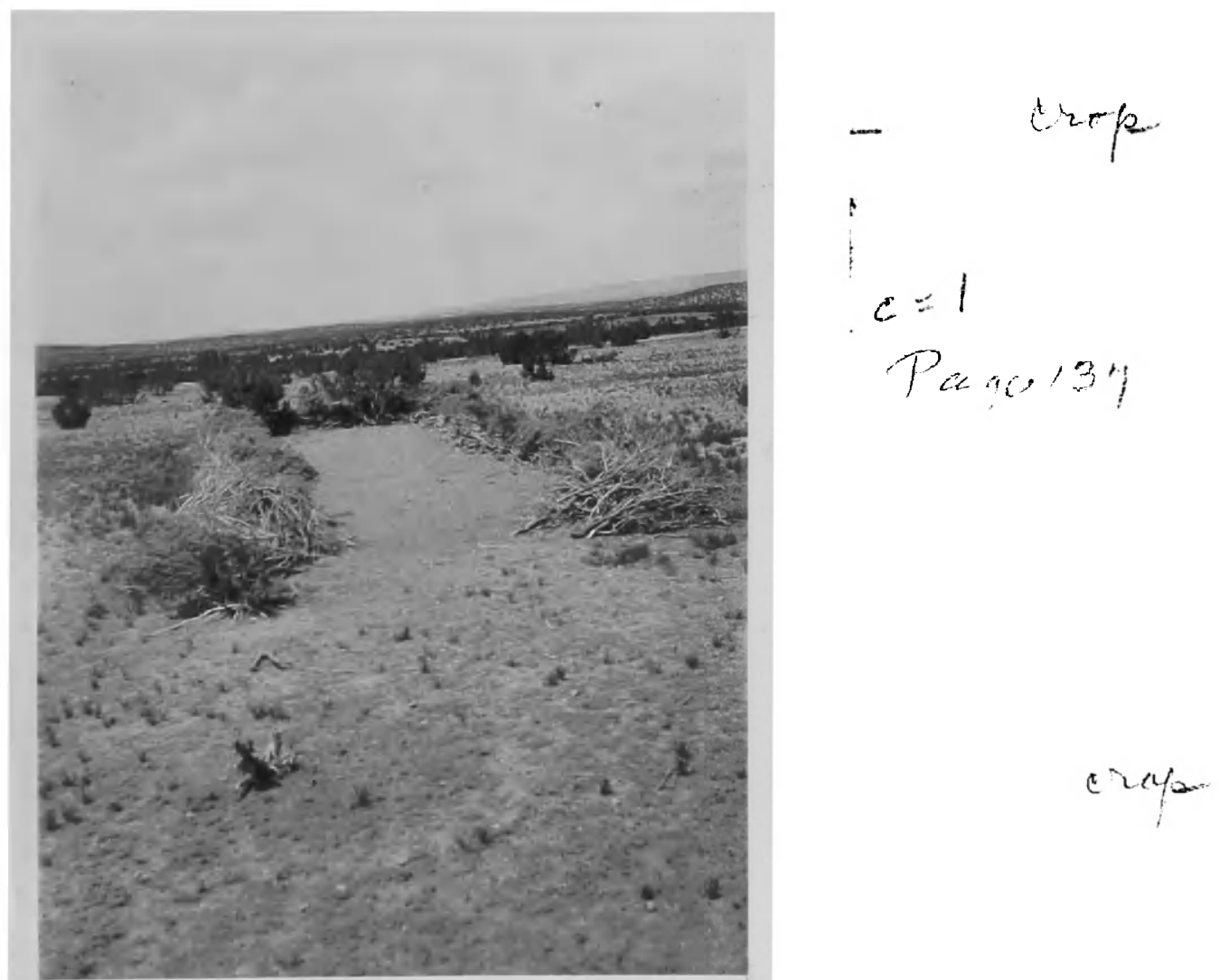

14. At Wight the sheep are Driven Into these Crude Corrale for protection against Promling Coyotes. 


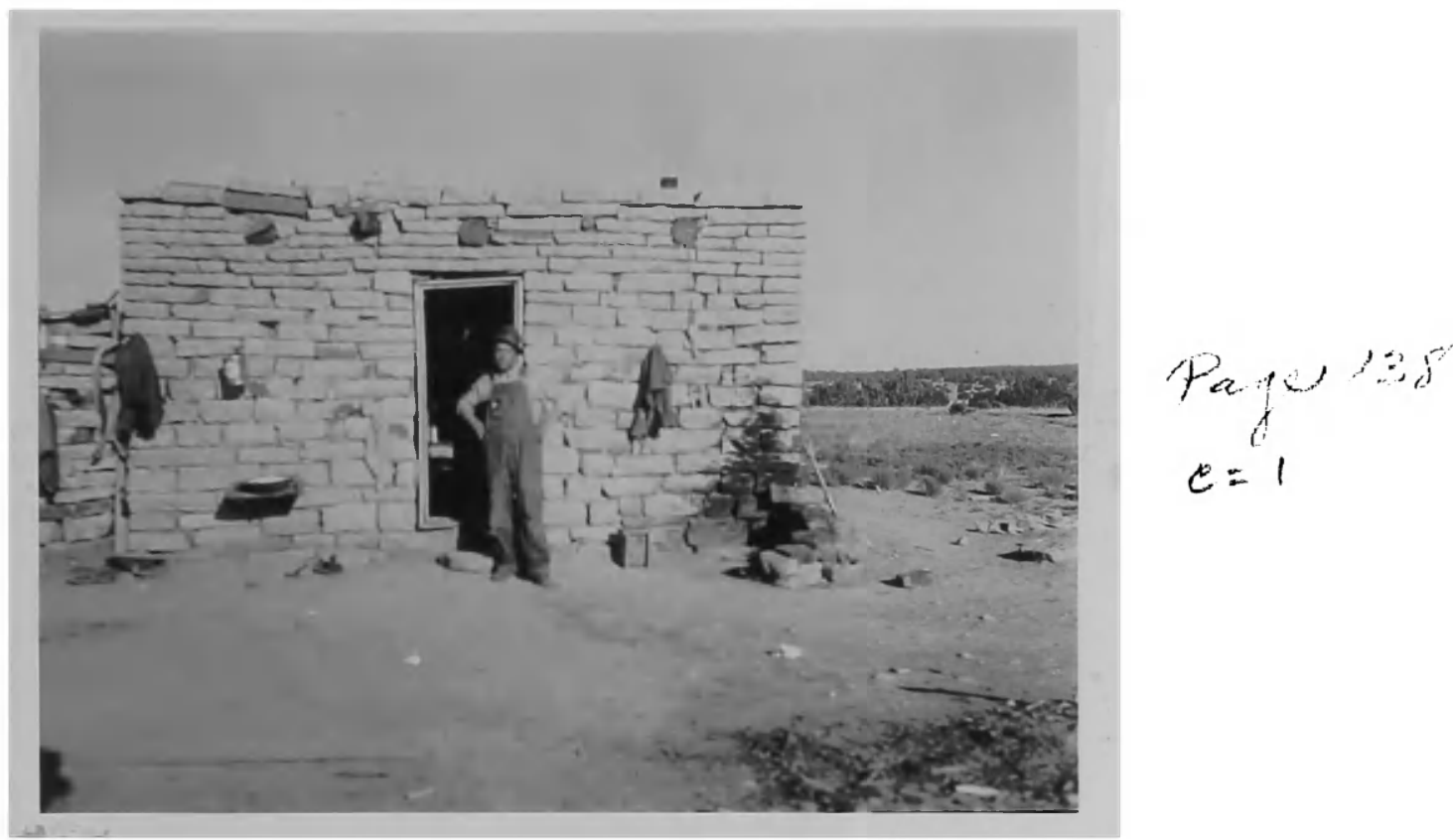

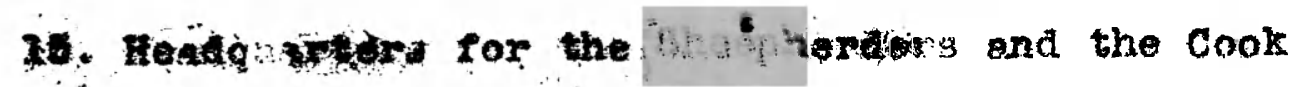

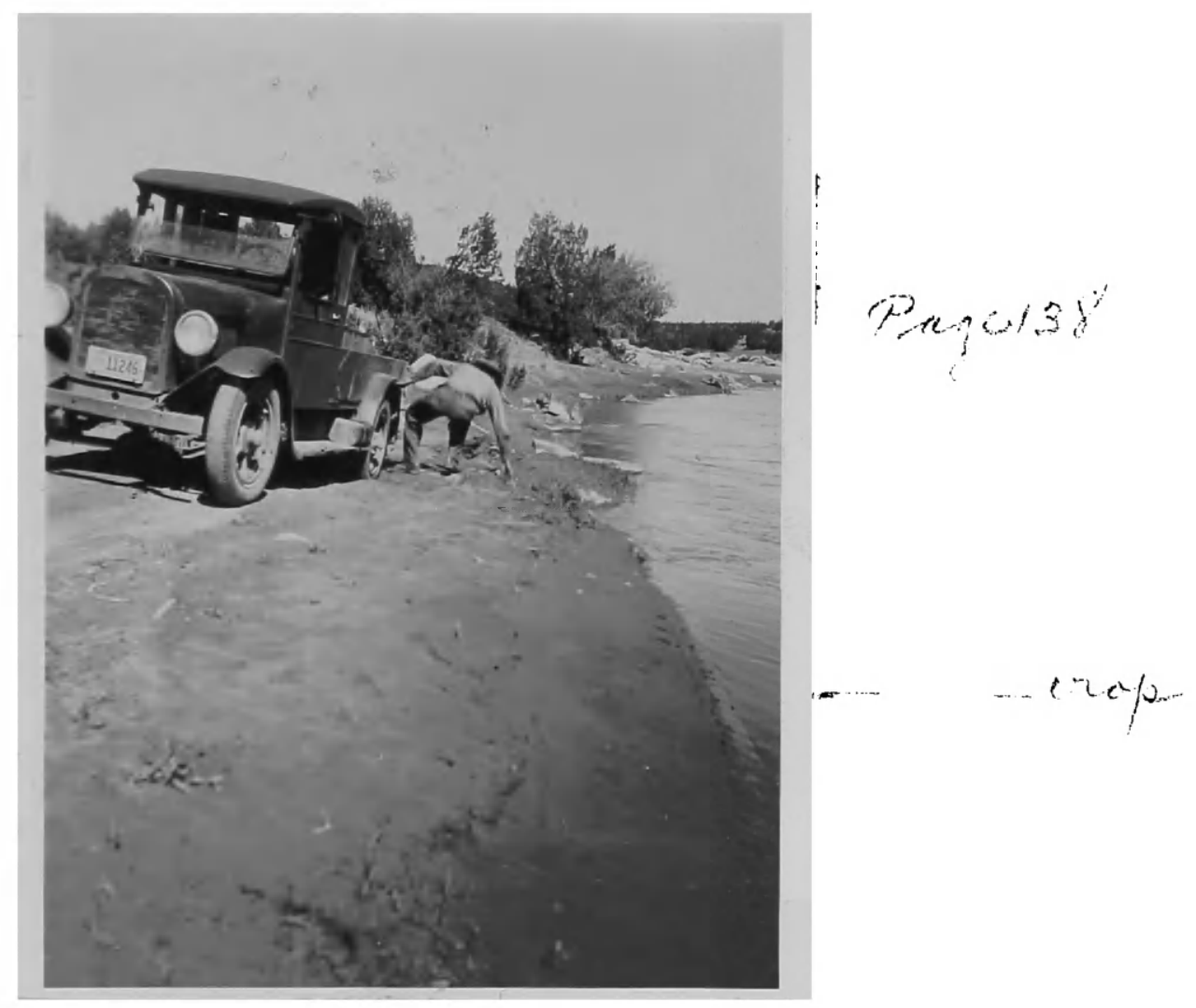

16. During the Dry seasons Wator Hust be Carried to the sheep 


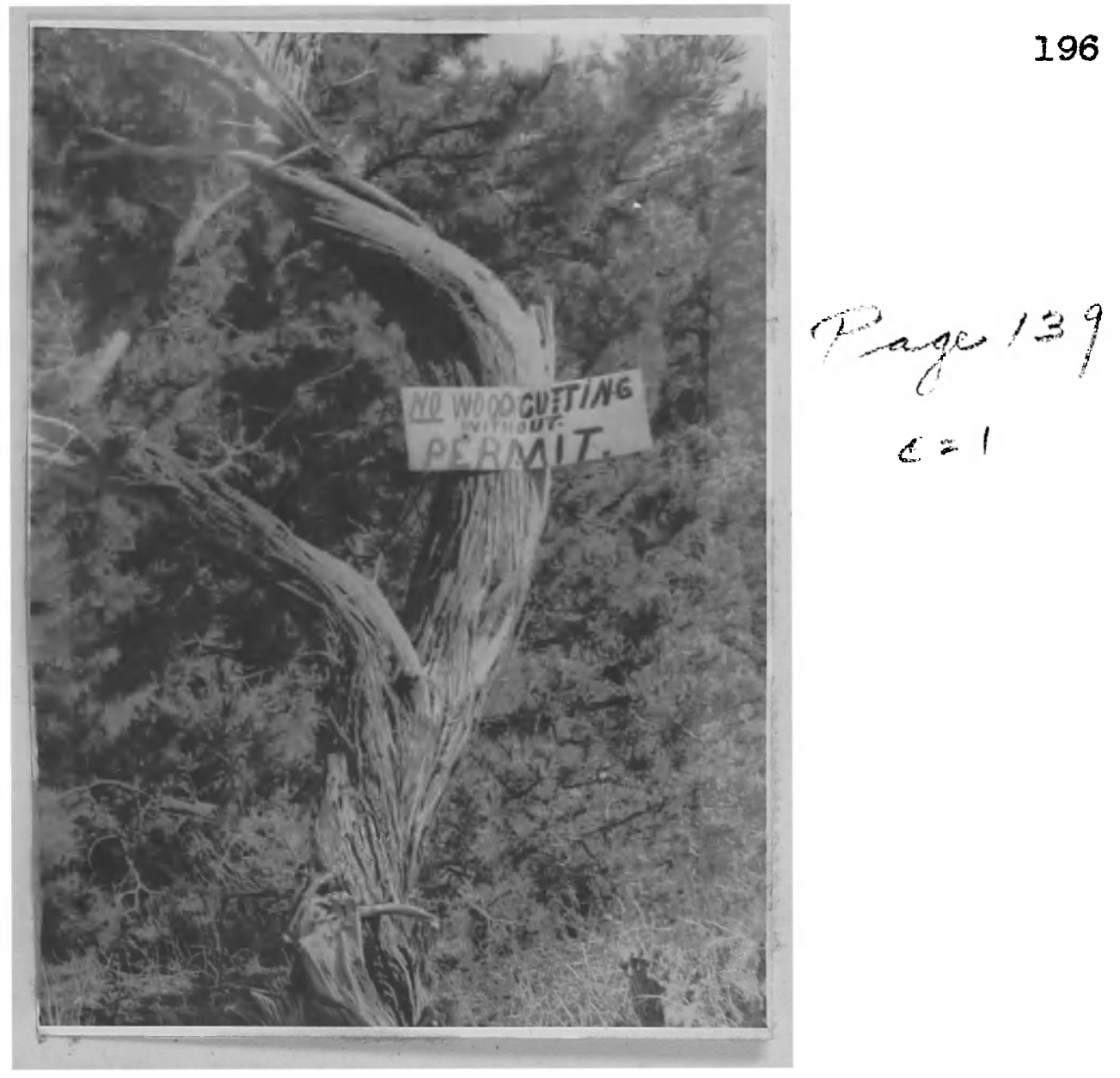

17. Notices such as that natives to Unders tana. 


\section{APPIDDX $\mathrm{B}$}

The documents in Apsendix $\mathrm{B}$ were taken from the 11 ses of the General Land office, Pubile survey office, U. s. Departaent of the Interior, Santa Fe, Mew Mextoo. 
Original Petition for the San Miguel del Bado Land Grant-- -

\section{A Translation}

I, Lorenzo Marquis, resident of this tom of Sante Pe, for mjoelt and in the nawe of 51 men aocompanying me, appear before your excelleney and state that, in consideration of having very large family, as well myself as those acoompanging me, though have some land in this town it is not suffleient for our support, on account of 1 to smaliness and the great scarcity of water, which owing to the great number of people we cannot all enjoy, wherefore we have enterea a tract of land on the Rlo Pecos, vaoant and unsettled, at the place comonly called El Vado, and where there is room enough, not only for us, the 51 who ask $1 t$, but also for everyone in the province not supplied. It boundarles are on the north the R10 de Ia Baca from the place oalled the rancheria to the Agua Caliente, on the south the Canon Blanco, on the east the Cuesta with the 11 thle hills of Bernal, and on the west the place comonly called the Gusano-which tract we ask to be granted us in the name of our sovorelgn, whom may cod preservo, and among these 51 men pet1tloning are 13 Indlans, and among them all there are 25 IIrearm, and they are the ame persons who appear in the 
abjolned 11st, whloh I present in due form, and we unan1mously and harmoniously ag one person do promise to enclose ourgelves in a plaza well fortified with bulwarks and towers, and to exert ourselves to supply all the firearas and anmunition that it may be poseible for us to procure. And as we trust in a compliance with our petition we request and pray that your Excellency be pleased to direot that we be placed in possession, In the Nase of his Foyal Hajesty our Sovereign, whom may God preserve, and we deolare in full legal form that we do not act with disoimulation.

\section{Lorenzo Marquis}

For himsel and the petitioners 
Original Decree for tho San Higuel del Bado Land Grant--

\section{A Tranclation}

On the 26 th day of the month of November, One Thousand Sever Endred ana Ninety-four, I, Antonio Jose Ortiz, Captaln In the militia and principal alcalde of the town of Santa Fo, In purauance of the order of Lieutenent colonel Femando Chacon, Inight of the order of Jantigo and alvil and mi11tary Governor of fints kingdon, before proceeding to the 81 to of El Vado, I, sala prinolpal alcalde, in compeny with two witnesees who were Xavier Ort1z and Doringo Santieateran, the 52 petitionere being present, caused them to comprehena the petition they had made, and informed then thet to recelve the grant they would have to obeerve and fulf111 in full form of law the following conditions:

First-- That the tract aforesald has to bo in coran, not only in regard to themelves but also to all settlers who way join then in the future.

Second--That with respect to the dangers of the place they ohall have to keep themselves equipped with firearas and bows and arrowg in which they hall bo inopected a well at the time of settling as at any time the alcalde in offlee maJ deem proper, provided that after two years settlement a11 the arme they have must be firearms, under the penalty that all who do not comply with the requirement shall bo sent out of the settiement. 
Th1ra--That the plaza they ay construct shall be according as expressed in their petition, and in the meantime they shall reside in the Puebio of Pecoe where there are suffielent acoomodations for the aforesald 52 Lanilles.

Pourth--Phat to the aloalde in office in sald pueblo they shall oet apart a shall separate ploce of land for hlm to cultivate for hinelf at his will, without thel chilaren or suecessors making any objection thereto, and the sane for h1s sucegsar in offleo.

Prth--That the contruation of thele plaza as well as the opening of altehes, and all other work that may be aeemed proper for the ccmon weIfare shali be perforat by

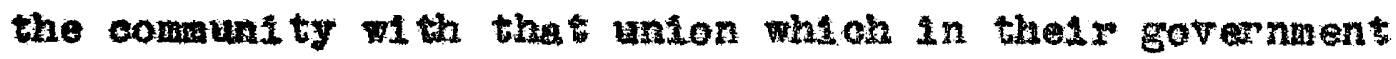
they wust preserve.

And when the wai beart and understood by each and all of the aforemontioned persons, they accordingly unanimously responded that they understood and hoeded what was communcated to then. Wherefore, I took then by the hand and announeed in elear and intelligtble worde that in the name of His Hajesty (God preserve Ifir) and without prejudice to the Royal interest or that of any third party. I lod then orer said Iande, and they placked up grasa, cast atoner and shouted "Long Live the King." Eaking paszession of sald land quietiy and peaceably, thout any objection; polnting out to them the boundarles, which are, on the North the Rlo de 
1a Baca roa the place called the Rancheria to the Agua Callente, on the South the Canon Blanco, on the East the Cuesta with the 11ttle hills of Bernal, and on the Fest the place comonis called the Gusano, notifying ther that the pastures and watering places are in common. And that in all time it may so appear, I, acting by appointiont, for want of a notary, there being none in this jarlediction, signed this with ny attending witnesses, with whon I act, to whioh I certify.

Antonlo Jose ortiz 
The San Migkel del Bado Land Grant--a Translation

\section{(gEAL)}

At thie place, San ufguel del Bado, del R1o de Pecos, Jurlsdiction of the Capitol town of Ganta Fe, New Hexico, on the 12th day of Harch, in the present year, one mousand glght Hundred and Three, I, Pedro Bautista PIno, Justice of Socond Note of the Town of Santa $P$ and 1 te juricalietion by verbal order of Colonel Fermando chaoon, Governor of this Province, have proceeded to tha eald settienent for the purpose of distributing the lands phich are under oultiva tion, to all the individuals who oocups ald settienent, and having exanined bald settlenent and having examined the aforescld cultiated land, I measured the whole of it from North to South and then proceeded to lay off and dride the several portions with the conourence of all the parties Interested, until the matter placed in orier, according to the means aysel: and the partices interented doened the best adopted to the purpose, in order that all should be satiefied with their posgegsions al though satd land is very wach broken on account of the many bende in the river, and arter the portiona were equally dividad in the best manner poselble, I caused there to draw lots, and each individuel drew his portion and the number of vares contalned in esch one portion was get down, as w111 appenx from the acoompanyling 
118t, which contalns the number of the ind1viduals who reside in this precinet, amounting to the number of 58 fam1110s, between whom all the land was divided, exeepting only the portion appertaining to the Justice of the precinct, as appears by the possession glven by the sald Governor, and another surplus portion which by the consent of all 18 set aside for the benepit of the blessed souls in Purgatory, on condition that the produets are to be applied annually to the payment of free massea, the certifleates for which are to be delivered to the Alealde in the offloe of sald jurisdiction. And after having made the distribution I proceeded to mark out the boundaries of sald tract from North to South, being on the Morth a hill situated at the edge of the river above the mouth of the ditch which 1rrigates sald lands, and on the south the point of the hill of Pueblo and the valley called remporales, a large portion of land remaining to the South, which is very necessary for the inhabitants of this town who may require more land to cultivate, which shall be done by the consent of the Justice of gald town, who is charged with the care and trust of this matter, giving to each one of those contained in the list the amount be mas require and can cultivate, and after having completed all the foregolng I caused them all to be collected together and notified them that they must each immediately erect mounds of stone on the boundaries of their land so as to arold disputes, and I also notifled them that no one was privileged 
to sell or alspose of tholr land until the expiration of ten years from this date, as directea by sald Governor who, if he is so pleased, w1II certify his proper approval at the foot of this dooument, of which a copy shell remain in this tow and the original be deposited in the Arch1veg where it properig belonge.

Pearo Bautista Pino

(By order of the Governor) 
Home Remedies Used in the Village of El Cerrito

Stomech Crampe--Eat the leaves of a native mint plant (Yerba de la neEFita). Also, a spoonful (teaspoon) of camphor in a tumbler of water and drink.

Fainting--Gut an onion in half and place the parts, alternately, under the person's nose. The aroma will revive him. In addition to this, wash the face of the person with cold water.

Sorethrost-A few drops of HefH mediclne in water and gargle. Baking Boda also good mixed with a ilttle sulphur.

Sores-- wash well with salt water and then apply dust found Inside the bark of sabina (Junlper) post.

Earache-Put a iftie perfume in the ear. Also, urine of a healthy child.

Falling hair--Boll the roots of a gourd plant and wash with it. Wash hatr in fresh, warn cow urine.

Freezing--Rub the affected part with onlon.

Headache--Apply vinegar on s1des of head and forehead. Place tobacco tamps on temples and forehead. Pull halr real hard several times. Apply Iresh sliced potato on templea.

Sore eyes-Wash with salt water.

Toothache--If the tooth is decayed burn out the decayed part with hot wire. Hold hot, salty water in the mouth. Chew the root of a plant called cardo-ganto.

Appendic1tis--M1x corn meal in water and drink it beforo Ereakrast. Drink a lot of hot salty cow milk.

Bolla--Apply poultices made from pine tree gum, yellow launary soap, ohicken aung or hot cow dung.

Itoh--Apply a mixture of Bulphur and lard before retiring.

Yose Bleeding--place olgarette paper between upper Iip and Bute - Burn alive frog, grind the remains and sprinkle around the nose. Be careful that none of the powder gees in the nose. If 1t does the bleeding will increase. Bum buffalo halr and inhale. Carry a gmall plint rock in the pocket at all times. 
Bed-wetting--Put a few drops of turpentine in water and drink once or twioe per day, especialiy before retiring. Rub HHH medicine on abajomen.

Burns and acalds-Apply writing ink on burned area. Also a mixture or lard, flour, baking sode and vinegar.

Corme--Soak corns in hot water for a few mutes, withdraw, dry and paint with indellble penoll. Yellow laundry soap also good.

Indigestion- A cooked paste made from nour, water, nutieg and oinnation.

Fever Bl1ster--Sprinkle blister with powder made from orange Finas.

Sty--Apply mashed $\mathrm{Hy}$ to affected part.

Removing polsoned blood from the body-Use ventosas or cuppling glasses over the Injured tissue. 


\section{BIBLIOGRAPHY}

Adsme, Herbert B. (Ba1tor), History, Politiog and gducation, Bal timore: The Johns Hopkins Prege, 1890.

Adams, James T. (Bditor), Dietionary of American History. Hew York: Charles Sorfbner Sons, 1940, vol. III.

Bell. Earl H., "goclal stratifleation in a Small Comanity," golentie Monthly, XXXVIII, 1934.

- Blackar, Frank Wlison, Spanioh Inst1tutions of the Southwest, Baltinore: The Johns Hopkins Fres, 1891.

Bloom, Lanaing B., and Donnelly, Thomas C., Mew Mexico H18 tory and G1710s, Albuquerque: the Univergity Press, 1933.

- Coan, Charles P., Alstory of New kexieo, New York: The American Hi tôrical \$oolety, 1925.

- Donalason, Thomas, The Publie Doma1n, House Mlscellaneous Document 45, 47th Congress, 2nd session, KIX. WeshIngton: Government Printing offloe, 1884.

- Dunham, Harold H., Government Handout, Ann Arbor: Eaward Bros., Ino., 194T.

Gedaes, Joseph A., Farm Yeraus V1liage Living, Utah Agr1cul tural Experiment Station BuIletin 249, Logan, 1934.

George, Henry, Our Land and Land Pollcy, New York: Doubleday Doran and Company, Ino., I911.

Gregg, Joseph, Comerce of the Prairied, Dallas: The Sou thwest press (reprint), I933.

Grigham, Glenn, El Pueblo (unpublishod), Amarillo: Farm Boouri ty AdnInistration, 1939.

House of Representatives, Executive pooument 73, 45 th congress, 2nd session, Washington: Government Printing off10e, 1878. 
Johansen, S1gura, The Soelal Organization of SpanishAnerican Villageg," The southwestern soclal selenee Quarter1y, v01. XXIII, 1942.

Ilein, Jullus, The Mesta: $\mathrm{g}$ tudy in Spanish Economio H1s-

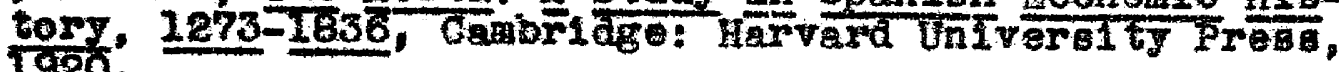
1920.

Kluckhohn, Florence R., Los Atarquenog, Cambridge: Harvard University (Ph.B. alssertation), 1940.

Leonard, olen, and Loomls, o. P., Calture of a Contemporary

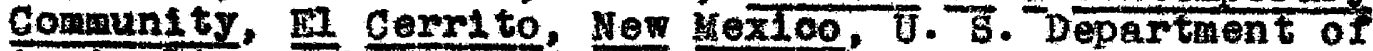

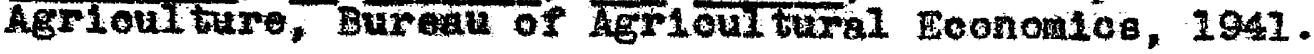

Linton, Ralph, The Study of Han, Hew York: D. AppletonCentury company, 1936.

Loomis, C. P., Informal Grouplngs in a Span1sh-American Village (mimeographed buTTetin), v. S. Departient of Agrioulture, Bureau of Agrioul tural Econom1es, 1940.

Loonl $B, C . P$. , and Leonard, O. E., Standards of Living in an Indian-Mexiean V1IIage and on a Roclemetion Froject, We GhIngton: U. S. Department of Agricul ture, 1938 .

MoBride, G. H., Chlie: Land and Soolety, New York: American Geographical 3001 ety, Research Series 19, 1936.

MacIrer, R. H., Soolety, A Textbook of Soolology, New York: Farrar and AInohart, Iñ., 19B7.

Haes, Ernest L., The Worla and the People of Cundiyo," Land Polloy Hevien, March 1941.

May, Mark A., and Doob, Leonard F., Competition and Cooperation, soclal golence Research Counoli bulletin 25 , Tew York, 1937.

Meneree, selden C., Mexican Higratory Workers of South Texas, Washington: Tork ProJects Agenoy, IS4.

Neloon, Lowry, A Boclal Survey of Escalanti, Utah, Brighan Young vniversity, 1925.

The Momon V111.ge: A stuay in Social origins, Provo: Brighar Young University, 1930 .

Some soc1al and Economic Features of American Fork, Utah, Frovo: Brigham Young University, 1933. 
Oberg, Kalervo, "Cultural Factors and Land-use Planning in Cuba Valloy, New Mexico," Rural Soc10logy, V, 1940.

Odum, Howard W., and Moore, Harry E., American Reglonallam, Wew Toxk: Henry Holt and Company, 1938.

Ogburn, W11l1am P., and Llak off, Meyer F., Soclology, New York: Houghton 硬iflin Company, 1940.

Powers, Stephen, Afoot and Alone, Hartford: Columblan Book Company, 18rz.

Public Survey Offloe, The Canyon de Ban Dego Grant, Report no. 25, File no. 60 , U. S. Department of Intarlor, General Land Offioe, Santa Fe, New Mexioo.

Publ10 Survey orf1ee, the Cundiyo Grant, Report no. 211, File no. 246, U. \$. pepartment of the Interior, Ceneral Land Orflce, Santa Fe, New Mexico.

Publle Survey orfice, The Jacone Grant, Report no. 92, File no. $168, U$. S. Departiant of the Interior, General Land office, Santa Fe, How Hexico.

Publ10 Survey offlee, The La Joye Grant, Report no. 95, File no. 169, U. S. Departinent of the Interior, General Land Offlce, Santa Fe, New Mexioo.

Publ10 survey offloe, The San Miguel del Bado Grant, Report no. 119, File no. 49, U. S. Departant of the Interlor, ceneral Land ofrice, Santa Fe, New Hexico.

Rowntree, B. S., Poverty, a Btudy of Town Life, New York: Longmans, Green and company, Toz2.

- Rusgell, John C., Htate Reglonalian in New Hexico," Soelel Forces, XIV, 1937.

Sanchez, George I., A Study of the scores of Spanish-3peaking Chilaren on Repeated regte, A master' theais, Austin: The University of Texas, 1931. Mexico 5ress, 1940 .

Sanderson, Dwight, Rural sociology and Rural Soc1al Drganization, New York: John Filey and Sons, $194 \overline{2}$.

San iniguel Rural Counc1l, A Survey of San Geronimo, Las Vagas: Highland Und versity, $19 \overline{36}$. 
San M1guel Rural Counc11, A Burvey of V11lanuera, Las Vegas: Highland Untversity, I936.

Sato, Shoouke, History of the Land Question in the United states, Johns Hopk Ing Tniver's 1 by Studies 1 in Hi storical and Poiltical sclence, Fourth series, VII-IX, Baltimore, 1886.

Simpson, Eyler N., The Ej1do: Mexioo's Way Out, Chapel Hill: The Untversity of Worth carolina press, I93?.

Skinner, Constance L., Ploneerg of the old Southwest, New Haven: Yale univeratiy Preas, I921.

Sm1th, T. Lynn, and Parenton, Vernon J., "Acculturation Arong the Loul siana Frenoh," The Amerioan Journal of Soc10I0g7, XLIV, 1938.

Sint th, T. Lynn, "An Analysis of Rural Soclal Organization Among the French-speaking People of Southern Loulsiana," Journal of Farm Eoonomies, XVI, 1939.

The Population of Loulsiana: Its Composition and Changeg, Loulsiana Agr Icul tural exp erinent Station Bulletin 293, Baton Rouge, 1937.

The goclology of Rural Life, New York: Harper and Brothers, 1940 .

Soll Conservation Servioe, Material on the Partido System, Albuquerque: $U$. S. Departinent of Apriculture, 1937.

Mex100, AIbuquerque: U. S. Departinent of Agricul ture, 1937.

Sen Miguel County V1lieges, Albuquerque: U. 3 . Department of Agri culture, 1938 .

of Agriculture, II, I959.

V1Ilage L1vel ihood in the Upper R1o Grande Area, ATbuquerque: U. B. Departraent of AgricuIture BuIletin, 1937 .

Sorokin, P. A., Soctal Mob111ty, New York: Harper and Brothera, 1927. 
Sorokin, P1tirin A., zimmerman, Carlo c., and Galpin, C.J., A SyBtematic source Book of Rural Sociology, inneapolis: Universi ty of MInnesota press, 1930-32, 3 vols.

Taylor, Carl C., Rural goclology, Now Yorik: Harper and Brothers, igss.

Treat, Payson d., The National Land system, 1785-1820, Hew York: E. B. treat and Company, 1910.

Twitchell, Ralph E., Leading Facts of Nes Mexican M18tory, Cedar Rap1dB: Torch Pross, I91T-1912, 5 Fo18.

U. S. Department of Agricul ture, Climate and Man; 1941 Toarbook of Agrioulture, Washington: Covernment Printing offloe, 1941 .

Falter, Paul, Jr., A Study of Isolation and Soc1al Change in phree Span1ah-apeak Ine villages of Nev Mexico, a Fh.D. Thesis, Stanford Untvera1ty, 1938.

Young, K1mball, An Introductory Soclology, New York: The American Bock Company, 1934. 


\section{BIOGRAPHY}

Olen E. Leonard was born on a Iarm in w18e County, Texas, on January 31, 1909. He recelved his grammar school education in two-room school of the county and finished high sohool at John Tarleton Colloge, Stephenville, Texas.

He recelved a.S. degree from the Mredertcksburg State Feachers College, Frederioksburg, Virginia, in 1931. After graduating he tatught in the publ1c schools of Loudoun County, Virginta, for three years when he resigned to acoept a job with the Federal Bureau of Investigation, 0. s. Departinent of Justice in Washington. In 1936 he acoepted a position with the Departaent of Agriculture in rashington where, for the next three years, he did graduate work at night in the American University. In the iall of 1940 he went on leave Prom the Department of Agrloulture to attend the Loulsiana State University where he did graduate work in Soolology unt1l the apring of 1942.

He is now exployed by the Division of Farm Population and Rural elfare, Bureau of Agricul tural Economics, as Area Leader of the Southeastern Region with headquarters In Atlanta, Georgia. 
EXAMINATION AND THESIS REPORT

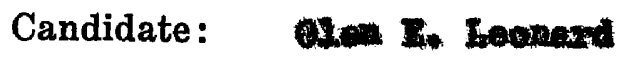

Major Field: Sectelest

Title of Thesis: The Role of the Lend Grant in the Social Onganfation and

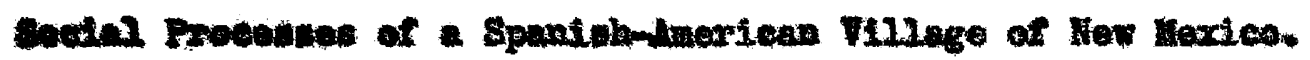

Approved :

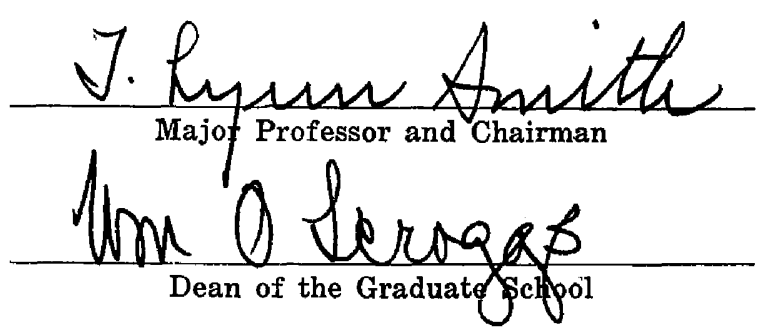

EXAMINING COMMITTEE:
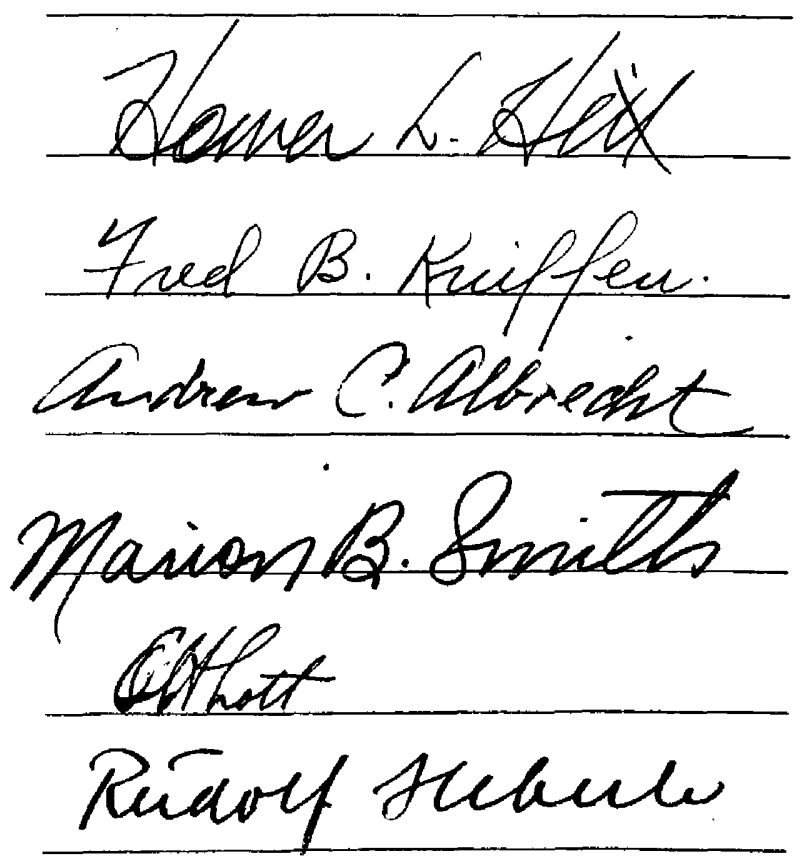